Alma Mater Studiorum - Università di Bologna DEPARTMENT OF ECONOMICS

\title{
SOC(HE)-Italy: a classification for graduate occupations
}

Luca Cattani

Kate Purcell

Peter Elias

Quaderni - Working Paper DSE N963

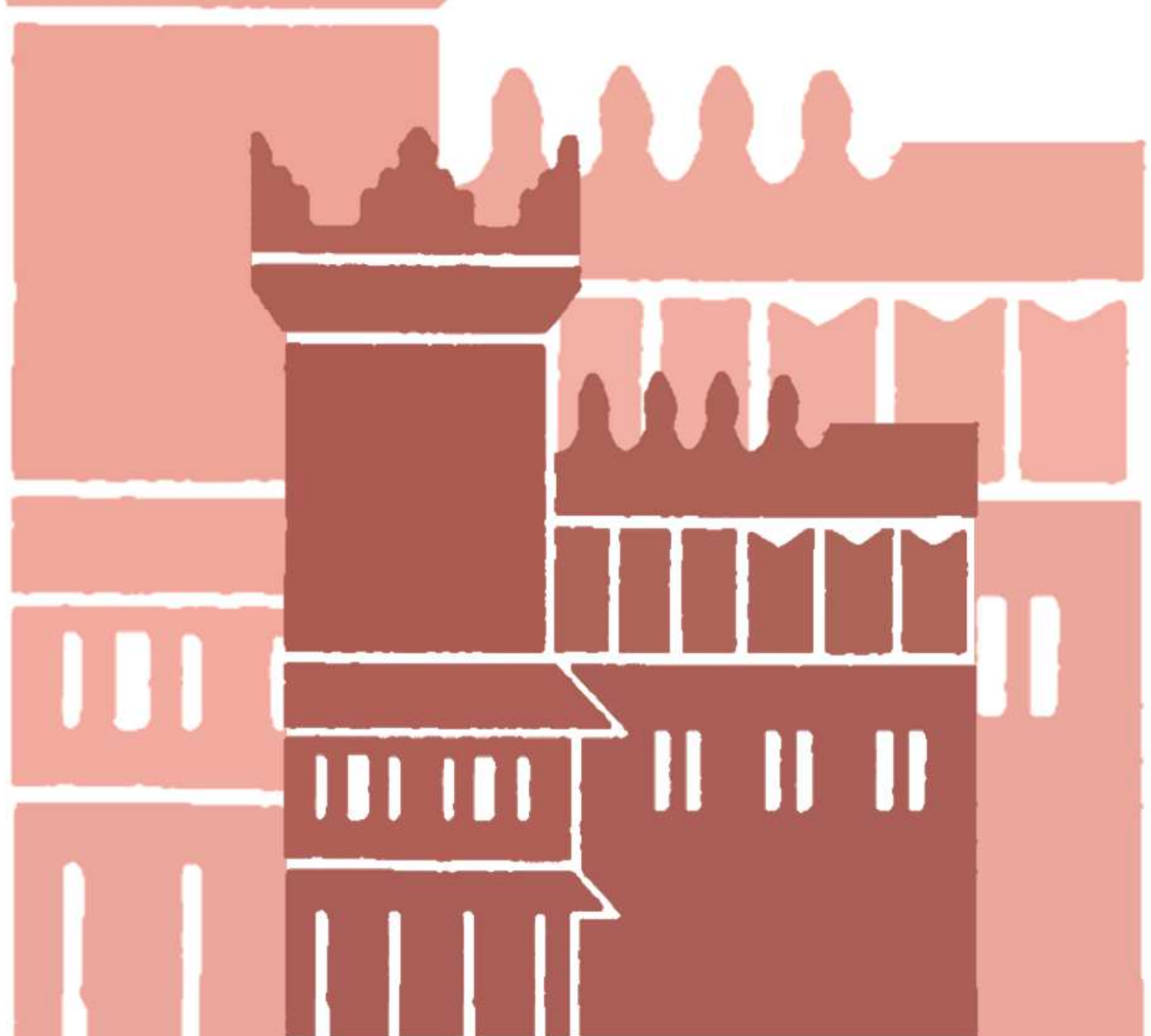




\title{
SOC(HE)-Italy: a classification for graduate occupations
}

\author{
Luca Cattani $^{*}$, Kate Purcell ${ }^{\dagger}$, Peter Elias ${ }^{\star}$
}

August 2014

\begin{abstract}
This paper presents an application to the Italian labour force of the British SOC(HE)2010 classification for graduate occupations, thereby creating a statistical tool for exploration of the Italian graduate labour market. In order to achieve this goal, the classification is replicated, using methodology that differs slightly to take account of differences in existing Italian data, to construct SOC(HE)-Italy. This classification allocates each of the official 800 Italian occupational categories to four groups distinguishing between 'graduate' and 'non-graduate' groups on the basis of their relative levels of knowledge and skills requirements. It is then validated using the Rilevazione Continua sulle Forze di Lavoro (RCFL ISTAT) data and the AlmaLaurea (AL) data and used to analyze changes in the Italian occupational structure that occurred before and after the financial crisis that took place in 2008. We also compare the Italian structural trends in the graduate labour market with similar trends in Britain. This analysis reveals that the decrease in the utilization of highly qualified labour in the Italian labour market started before the beginning of the ongoing recession, which contradicts the findings of analyses reported in earlier literature.
\end{abstract}

\section{JEL classification: $\mathrm{I} 2, \mathrm{~J} 2$}

Keywords: graduate labour market, occupational classifications, skills, higher education.

\section{Corresponding author:}

Luca Cattani

Dipartimento di Scienze Economiche

Strada Maggiore, 45 - 40125 Bologna (Italy)

@: 1uca.cattani@unibo.it

\section{Acknowledgments}

This paper has been written relying on analysis of AlmaLaurea data: we are grateful to Andrea Cammelli, Angelo Di Francia and Silvia Ghiselli for their support and their useful comments and suggestions. We have also utilised data from the ISTAT survey on Italian professions and from the ISTAT Survey on the Italian labour force (RCFL): analyses of these data have been our responsibility. Usual disclaimers apply.

\footnotetext{
${ }^{*}$ University of Bologna, Economics Department.

${ }^{\dagger}$ University of Warwick, Institute for Employment Research.

${ }^{\ddagger}$ University of Warwick, Institute for Employment Research and University College London, Institute for Child Health.
} 


\section{Introduction}

In this paper the utilization of highly qualified labor in advanced economies is analyzed both in terms of incidence and in terms of returns to education. The former approach focuses on changes in national occupational structures including investigation of the creation or evolution of new and pre-existing jobs, while the latter emphasize the explanatory role wages play when analyzing the fit between supply of and demand for qualified labor. In Italy, studies on the topic (AlmaLaurea, 2012; CNEL, 2012) directly apply the national occupational classification which is based on the conceptual basis embodied in the structure of the 1988 version of the International Standard Classification of Occupations (ISCO88). Following this international standard, Italian occupational groups and job-titles are ranked according to assessment of the level of skill required to undertake them effectively, grouped into four skill levels within eight aggregate categories termed Major Groups. Changes in the distribution of the employed labour force over these groups are monitored so that, for example, the expansion through time of the first two or three groups is taken to indicate increased demand for highly skilled labour. Although educational qualifications are included in the criteria applied in classifying occupations, neither ISCO nor the Italian classification refer solely to the knowledge and skills imparted in Higher Education (HE) when establishing the skill level of the professions they rank. Reference is also made to the required work experience and the nature of the tasks and duties typically associated to that job. As a consequence, occupational classifications cannot be interpreted at the broad level of Major Groups when trying to distinguish between 'graduate' and 'non-graduate' jobs in order to assess changes in the occupational structure or assess the extent to which graduates are or are not entering appropriate employment for people with their qualifications.

In recognition of the need to monitor the impact of $\mathrm{HE}$ expansion and its impact on occupational change and opportunities available to labour market entrants, a new classification of occupations, named SOC(HE) has been developed for the UK by Elias and Purcell (2004; 2013) to investigate the relationship between the knowledge and skills acquired in HE and the jobs new graduates were entering in their early careers. We now develop a new measure, SOC(HE)-Italy, based on SOC(HE) but differently constructed, to analyze changes that have occurred in the Italian occupational structure between 2004 and 2010 and aiming at a comparison with the trends recorded in the pre-existing literature before and after the financial crisis that took place in 2008. Paragraph $\S 1$ introduces SOC(HE) and its conceptual basis along with a brief review of some theoretical issues concerning occupational classifications and their applications. In paragraph $\S 2$ we present an in-depth description of the construction of 
SOC(HE)-Italy and its validation using ISTAT and AlmaLaurea data. Paragraph $\S 3$ contains the analysis of the changes occurred in the Italian occupational structure and a brief comparison with the British case.

\section{Classifying occupations and measuring skills}

It is hard to evaluate changes in the occupational structure generated by economic growth and technological development without reference to the occupational classifications through which such structural changes are recorded. While statisticians require classifications which are reasonably stable through time, changes in occupational structure bring pressures to update classifications on a regular basis. The advent of 'the knowledge society' quickened such transformations with the appearance of new jobs or alteration of the cognitive contents and the tasks typically associated with some pre-existing professions. More specifically, many jobs traditionally considered as manual labour have come to encompass a number of non-manual tasks with higher levels of skill or knowledge requirements (Kochan et al., 1999). On the other hand, massive updates resulting in radical transformations of these classifications can actually hamper the possibility of building consistent time series. Moreover, it has been observed that operators in the field such as administrative staff in employment offices can either be reluctant to abandon established classifications or concerned to defend their own interests in shaping the new one (Elias and McKnight, 2001). Strategies to combine these two opposing needs has brought in many cases (Gallo et al., 2007; Elias and Purcell, 2004; 2013) to integrate rather than replace traditional instruments with new classificatory tools, designed to make sense of relationships among jobs according to their relative cognitive contents. Referring to the knowledge society and the graduate labour market, the aim of the UK authors has been to

“...put 'the knowledge society' under the microscope by looking at the jobs that graduates do and the knowledge required to do them." (Elias and Purcell, 2013)

Broadly speaking, many attempts have been made to synthetize the new occupational and skill structures. The need to make reliable comparisons between countries led researchers and theorists to develop taxonomies of highly aggregated major groups. Reich's (1991) 'three jobs of the future' are a good example of such aggregations: Americans, according to this view, were essentially employed in one of three categories: 'symbolic analysts', 'in-person services' or 'routine production workers'. The conceptual basis of these three categories comes close to embodying the distinction between different utilizations of knowledge on the job. Especially the first and last category refer exclusively to the nature of the job and the type of utilization of 
knowledge the job requires. Symbolic analysts are those workers who produce or manipulate knowledge, often exposed to international competition and asked to find innovative solutions. Routine production workers are, at the other extreme, those employed in mainly routine and repetitive tasks, asked to follow instructions rather than consider options. Many of these jobs correspond to the old unskilled production workers in both manufacturing and services, possibly upgraded and enriched with immaterial tasks as in Kochan et al. (1999) - in jobs such as data entry, software re-coding, call centers, etc, but, from a more cynical perspective, often remarkably analogous to routine factory workers of previous generations, engaged in 'digital Taylorism' (Brown et al. 2008). Unfortunately, for the second category of workers described in Reich (1991), those employed in in-person services, there is no implicit reference to level of skills or knowledge utilization and consequently, it cannot be subjected to the analysis we propose.

Reich's intention was to rank jobs by sectors rather than by the use of knowledge and with reference to his three main categories of occupation it is relatively straightforward to identify three sectors ranked by innovativeness and global competition exposure. Following this perspective, Reich could be considered as precursor of Moretti's (2013) "three Americas": the first one (e.g. Silicon Valley) is highly dynamic and innovative and engaged as a forerunner in global competition. At the same time, the concentration of human capital in urban areas will act as a multiplier attracting in-person services, increasing their relative demand and thus raising employment and wages in all sectors; the second (e.g. the old "Rust Belt") is composed of those traditional productions exposed to and beaten by international competitors such as China and Brazil with relatively cheaper unskilled labour forces; the last one is lying in between the two and will end up, sooner or later, getting promoted to the first one or relegated to the second one. All in all, Reich's view appears more evocative of job descriptions based on the relation between jobs and knowledge and it is, interestingly, consistent with recent studies aimed at describing different types of 'knowledge workers'. Brown et al. (2011) classified these as developers, demonstrators and drones: the first and last remarkably close to Reich's symbolic analysts and routine production workers, and their classification is also subject to the same criticism. The 'developers' category appears to be confined to the most senior management, research and professional occupations, graduates in 'drone' occupations are by definition overeducated for the posts they fill, but 'demonstrators' cover a very diverse range of occupations that require skills and knowledge to a greater or lesser degree. For both Reich and Brown et al., the knowledge and skills of those in their middle categories, given the heterogeneous nature of occupations in these categories, are inappropriately lumped together, with skills and knowledge levels implicitly reduced to the lowest common denominator. Reich 
was concerned to analyse the labour force as a whole, whereas Brown et al's interest is confined to the graduate labour market and their taxonomy appears more oriented towards hiring standards than to the direct linking between knowledge imparted via higher education and the knowledge and skills required to carry out a job. This is a constraint that must be taken into account when analyzing graduate jobs, because hiring standards may account for credential inflation or signaling rather than for cognitive contents associated to the assigned tasks.

Our purpose is to develop a classification capable of assessing in a more direct manner the relationship between the knowledge acquired via Higher Education (HE) and the knowledge used on the job, so there is no way to avoid reference to the nature of the jobs we are classifying and the cognitive contents (knowledge, skills and competences) they encapsulate. A job should then be defined as a graduate job only if competent performance within the job requires the skills and knowledge imparted via study on an HE undergraduate or higher-level course. As participation in HE in the UK has grown, Elias and Purcell have been concerned to evaluate the extent to which graduates were or were not accessing appropriate employment for people with their skills and qualifications. In 2004, they developed a new occupational classification, $\mathrm{SOC}(\mathrm{HE})$ to monitor change in the UK graduate labour market, based on detailed analysis of trends in occupational structure and the proportions of graduates within these detailed categories, using UK Labour Force Survey data and a series of national graduate tracking studies (Elias and Purcell, 2004). It received considerable attention among policy makers, analysts and careers advisers in the UK and its potential has also been explored with reference to Brazil, Portugal and India (Comin et al., 2010; Raffery and Dale, 2008; Basant and Mukhopadhyay, 2009; UUK, 2010; HEFCE, 2011; Figueiredo et al., 2011; Unni and Sarkar, 2011). However, application of the original SOC(HE) to very different labour markets with substantially lower HE participation such as Brazil and India revealed the classification's limitations for international comparison and inspired the authors to develop a radically revised version, SOC(HE) 2010 (Elias and Purcell, 2013). The application of this revised classification to the Italian labor force thus constitutes a test of SOC(HE)2010 as a useful tool for comparative research between countries, as well as a potentially valuable way to investigate trends in the Italian graduate labour market.

\subsection{Occupational classifications}

Official occupational classifications based on the International Standard Classification for Occupation (ISCO88 and its last update ISCO08), such as the British SOC and the Italian CP, 
do recognize the need to define a job regardless the employees' characteristics and to link it to some extent to a certain level of skills. According to the International Labour Office (ILO) a job is defined as a set of tasks and duties performed or designed to be performed by one person, characterized by a high level of similarity. Since its first attempts to define an international classification, ILO has focused on the nature of the work performed and has gradually shifted the attention on the skills needed for competent performance of constituent tasks rather than on the economic sector of activity (e.g. the NACE sectors) or on the social position employees occupy, given that these dimensions tend to differ between countries and hamper comparability. Skills were in turn defined as the ability to carry out the tasks and duties of a particular job, articulated into two different dimensions, namely skill level and skill specialization. (ILO, 1990; 2012). Skill specialization refers to the required fields of knowledge, which may vary by economic sector and/or the materials worked on or services provided. The level of skills required by a particular job refers, on the other hand, to the complexity and range of its constituent tasks and duties and the amount of formal and informal education and work experience needed to competently perform them. The concept of skill level and its operationalization in ISCO88 represented a significant innovation in the ILO standard and it is considered to be, along with political and historical facts ${ }^{4}$, the major source of the increasing consensus and popularity of this international standard.

4 Elias (1997) and Gallo and Scalisi (2012) attribute the success of ISCO88 as a global standard also to the larger involvement of national statistical offices, adoption or alignment by the UK, Australia and $\mathrm{EU}$, the collapse of Soviet Union and the consequent need for Eastern European countries to substitute the obsolete socialist classifications. 


\begin{tabular}{|c|c|c|c|}
\hline & \multirow[b]{2}{*}{ Major Groups } & \multicolumn{2}{|c|}{ Skill Level } \\
\hline & & ISCO88 & ISCO08 \\
\hline 1 & Managers & - & $3-4$ \\
\hline 2 & Professionals & 4 & 4 \\
\hline 3 & Technicians and associate professionals & 3 & 3 \\
\hline 4 & Clerical support workers & 2 & 2 \\
\hline 5 & Service and sales workers & 2 & - \\
\hline 6 & $\begin{array}{l}\text { Skilled agricultural, forestry and fishery } \\
\text { workers }\end{array}$ & 2 & - \\
\hline 7 & Craft and related trade workers & 2 & - \\
\hline 8 & $\begin{array}{l}\text { Plant and machine operators and } \\
\text { assemblers }\end{array}$ & 2 & - \\
\hline 9 & Elementary occupation & 1 & 1 \\
\hline 0 & Armed forces & - & $1-2-4$ \\
\hline
\end{tabular}

Although skill levels in table 1.1 are referred to ISCED categories ${ }^{5}$ as suggested by the ILO, this does not imply that competences needed to carry out jobs encompassed in these Major Groups are acquirable only via formal education, as they could be achieved through work experience as well (ILO, 1990). Moreover, skill levels are now further articulated into three operational measures: the nature of the work, the formal educational and vocational qualifications normally required to access the job and the less formal training or work experience. Formal education is neither the only possible measure of skill levels in order to define jobs in ISCO08 nor the most important one:

"The concept of skill level is applied [...] giving more emphasis to the first of these operational measures, the nature of the work performed, than to the formal and informal education and training requirements." (ILO, 2012)

5 Categories displayed in table 1.1 are referred to ISCED76 classification that ranks qualifications as follow: Level 1, primary education; Level 2, secondary education; Level 3, Upper secondary education not giving a university degree; Level 4, tertiary education. We kept these categories unaltered although a new version of the classification (ISCED1997) is available since 1997 and could be applied to ISCO08: this decision reflects the choice to directly compare ISCO08 with the older ISCO88 version when ISCED76 was utilized. 
These circumstances limit the extent to which ISCO08 structure is capable of proxying the level of utilization in the workplace of knowledge and skills acquired via HE. Many managerial occupations may, for instance, require more work experience than formal education and Major Group 1 cannot be thus defined as a group encompassing graduate jobs only.

On the other hand, the Italian national statistical institute (ISTAT) acknowledged starting from the 1990s the developments of the last two ISCO iterations and ILO definitions of job, job titles and skills. A job is now more broadly defined as a set of working activities performed by one person, entailing a system of knowledge, competences, identity and relationships. The Italian occupational classifications (CP) that followed ISCO88 in 1991, 2001 and 2011 embodied the definition of skill and its articulation into skill level and skill specialization, thus applying the ISCO conceptual basis. Although Italian CP2011 has less Major Groups compared to ISCO08 (ISCO Groups 6 and 7 are collapsed into one category), it fully applies the ranking of jobs based on the required level of skill, accounting also for the levels of autonomy and responsibility usually associated with professions, the assigned tasks and the field of specialization; where the first two allocate job titles vertically along the Major Groups and the last defines, horizontally, the relevant field of knowledge or economic sector (ISTAT, 2001). Since 2006 the Italian classification differs from the International standard in terms of the number of digits (5 rather than 4), with an additional level (named "Categoria") between the 3digit level ("Minor Groups" in ISCO08 and "Classi" in Italian CP) and the 4-digit level ("Unit Groups" in ISCO08 and "Unità professionali" in Italian CP), which in turn now comes to occupy the 5-digit level in the Italian classification. This iteration of CP2001 was termed NUP (Nomenclatura Unità Professionali) and constituted a basis for the development of the new version of CP, the CP2011. In the same year a study group with members from ISTAT and the Italian institute for vocational training (ISFOL) ran the first survey on Italian professions aiming at developing a new tool for linking the knowledge and skills required in a particular job and formal qualifications as articulated in the European Qualification Framework (EQF) ${ }^{6}$. This attempt to link directly the knowledge imparted via formal education and the knowledge used in the work place can be fully ascribed as part of the international debate on the integration of traditional classificatory tools to measure and describe changes in national occupational structures, with a specific focus on graduate jobs (Gallo et al., 2007). The major

6 The European Qualification Framework (EQF) consists in a transnational translation device and was issued by the European Commission in 2008 to make different national qualifications more readable across the continent and 'promoting workers' and learners' mobility between countries and facilitating their lifelong learning" (Recommendation 111/2008). It relates all European national qualifications to 8 major levels, referring to knowledge, skills and competences acquired in their relative education/training processes. We will discuss more in depth this device in subparagraph $\$ 2.2$ 
outcome of this study group consisted in a translation device that referred each of the 800 Italian job titles to a certain EQF level, and this is of much interest with respect to our goal to provide a new statistical tool or classification capable to measure the utilization of highly qualified labor in the labor market.

Before proceeding to present and discuss $\mathrm{SOC}(\mathrm{HE})$ and its Italian application it is salutary to consider the theoretical and statistical properties a classification should have in order to guarantee the robustness of the classified data ${ }^{7}$.

a) Reliability. Information obtained from the same classification process but from different data or in different periods should produce consistent results, within a normal tolerance of statistical variation stemming from sampling procedures;

b) Validity. Variables measured in a given sample should therefore reflect the relative values in the population from which they are drawn without systematic bias. If it is known, for instance, from the 2011 census on Italian population that $18.7 \%$ of Italian workers are graduating, the corresponding purpose in the sample should not differ from this benchmark in a statistically significant way. These two first properties can be considered as part of a same concept named technical derivation: the extent to which methods adopted to obtain information from data are replicable;

c) Theoretical underpinnings. A classification should be as coherent as possible in relation to the theoretical concepts it intends to represent.

d) Homogeneity/heterogeneity of the categories. There should be a minimum level of homogeneity within the categories identified by the new classification and a reasonable level of heterogeneity among them, otherwise it would be hard to extrapolate useful information about patterned social or economic difference or trends..

When considering occupational classification, the consistency of coding procedures of job titles is a major concern. Elias (1997) reported results from seven studies which operated two different coding procedures on the same datasets and investigated the consistency of occupational allocations among these. These recoding studies highlighted how occupational coding can be described as an "inexact process" leading to significant differences according to the different types of coding procedure adopted. Nonetheless, disagreement among coders (or between coding procedures) often occurs at more disaggregated levels, resulting in different codes falling in the same Major Group. As a consequence, levels of agreement consistently increase with the level of aggregation, reporting on average less than $75 \%$ workers identically

7 Properties listed and summarized in this subparagraph refer to Elias (1997), Elias and McKnight (2001) and Goldthorpe (1988). 
allocated at the 3-digit level (Occupational Units) and more than $85 \%$ at the 1-digit level (Major Groups). In the context of transnational comparability, this means that comparisons made at more detailed levels (e.g. 3-digit) are subject to constraints in this reliability and validity while comparing more aggregated levels (e.g. 1 and 2 digit) should benefit of a reasonable trust.

\section{$1.2 \mathrm{SOC}(\mathrm{HE})$}

As discussed in Subparagraph $\S 1.1$ above, in the course of their research on graduate career paths, Elias and Purcell (2004) developed SOC(HE), an aggregate occupational classification to measure the extent to which highly qualified labour is utilized in the UK labour market. They based this classification on the British Standard Occupational Classification (SOC2000) in order to meet three major needs: referring to the nature of the work performed and its required skill/knowledge level (granted by the conceptual basis of ISCO embodied in SOC); referring data to the national dimension avoiding long and costly additional data collection procedures (and thus relying on Labour Force Surveys data); enabling the construction of time-series indicators to evaluate evolutions in the occupational structure. Basically, building SOC(HE) consisted in allocating the 353 units groups of SOC2000 in two broad categories, "graduate" and "non-graduate" jobs, linking explicitly unit groups to formal qualification thus assessing that their relative tasks and duties required or not knowledge and skills, acquirable via HE only, to be competently performed. In the first version, termed SOC(HE)2000, the "graduate jobs" category was further disaggregated into four subcategories on the basis of differences between age groups in terms of the share of graduates employed in such unit groups: traditional graduate jobs, comprising the established professions for which entrants are normally required to be qualified, such as solicitors, doctors and professors; modern graduate jobs, in which graduates have been employed since the educational expansion in the 1960s, such as managerial occupations, IT, Knowledge Intensive Business Services and creative vocational areas; new graduate jobs, which entry route has only recently changed and now requires candidates to have a degree, such as marketing and sales managers or physiotherapists; niche graduate job, representing the boundary between 'graduate' and 'non-graduate' professions and where the majority of incumbents do not possess a HE title but with stable and increasing niches normally only accessible to specialists trained via HE, like nurses, midwives, hotel managers in multi-national companies, etc. This taxonomy, properly validated, allowed for measurement with time-series the expansion in the utilization of graduate labour during the 1980s and 1990s. According to SOC(HE)2000, more than 35\% of the British labour force was 
employed in a graduate job in the year 2000, $10 \%$ more than in 1975. This increase was assumed to be due to the stable and consistent growth in jobs belonging to 'modern graduate' and 'new graduate' groups, boosted by technical and organizational change that accompanied the advent of the knowledge society.

Despite the above mentioned raised interest and the applications to other national contexts, Elias and Purcell (2013) were concerned about the sustainability over time of such conceptual bases, rooted in statistical thresholds subject to further changes, as graduates continued to crowd the labour market, increasingly being employed in jobs and sectors which could hardly be defined as requiring HE preparation. All in all, the operational definitions of the SOC(HE)2000 categories seemed to insufficiently translate the need to focus on the nature of the job and the assigned tasks, capturing market outcomes that could be accounted for, like for in Brown et al. (2011), hiring standards and qualification inflation as well. Simultaneously, the need to make this analytical method more transferable across nations suggested to base it onto the relationship between "higher education, knowledge development and its labour market application", focusing on the type of use of knowledge made on the job post.

Reference was made to three clusters of competence identified in a previous study (Purcell et al., 2004) in which 220 British graduates were interviewed seven years after graduation to assess the nature of their work with respect to tasks, responsibilities, interpersonal relationships, knowledge and skills. These clusters were termed 'knowledge', 'strategic skills' and 'interactive skills' and re-defined in the new classification as:

a. Specialist expertise deriving from HE knowledge. This is basically "detailed knowledge and/or skills for which the normal foundation is an undergraduate degree course and where these are continually being exercised, developed and/or refined in practical and/or theoretical terms";

b. Orchestration expertise. Based on "high-level competence based on knowledge and skills that may have been developed either in HE or through experience (and most often, both of these). It incorporates the ability to draw together knowledge and knowledge-holders, to direct and co-ordinate activities, assess alternatives, evaluate risks and influence or make high-level decisions on the basis of available evidence";

c. Communication expertise. Consisting in knowledge and skills, normally involving welldeveloped interactive skills, concerned with the exercise of high-level competence in the communication, dissemination and use of knowledge, ideas and information, between individuals, within groups, or for mass-production or consumption, delivered in person or using digital media.” (Elias and Purcell, 2013) 
Each job, at the 4-digit unit group of SOC2010 was assigned a score on a 1-9 scale for each of these three dimensions, according to the degree of utilization it required of these abilities and considering a minimum score of 6 as indicative of a level of knowledge or skills normally imparted via HE. The scoring methodology can be described as a qualitative job analysis carried out separately by the researchers on the basis of information contained in the official classifications coding manuals, who then debated and resolved differences where their initial scores did not match. Unit groups not scored at six on any of the dimensions were classified as non-graduate jobs and those where the score on one or more was six or above were thus allocated to one of the following three occupational categories, according to the highest score or, in the few cases where two were equally high, the one that most closely defined their capacity to obtain or do the job. The categories were as follows:

Experts: workers in knowledge-intensive occupations, requiring the utilization and production of specialist HE knowledge and skills. Hiring standards and the capacity to competently perform tasks and duties associated to such jobs are directly related to possession of specialist knowledge and/or high level skills. Examples include solicitors, civil and mechanical engineers, physiotherapists and chemical and physical scientists.

Orchestrators (or Strategists): workers often employed in managerial activities and required to orchestrate their knowledge and the knowledge of others to "evaluate information, assess options, plan[s], make decisions and co-ordinate the contributions of others to achieve objectives" (Elias and Purcell, 2013). Managers and directors are Orchestrators: a group which also includes national and local government senior administrative occupations, senior officers in the police force and in other public sector areas.

Communicators: workers employed in media, advertising, teaching and some areas of the professionals whose major activity consists in transmitting knowledge or information to others. These jobs entail substantial use of interactive skills, be they 'interpersonal skills, creative skills or high-level technological knowledge, capacity to access and manipulate information and/or an understanding of how to communicate information effectively to achieve objectives' (ibid). The Communicator category includes journalists, actors, public relation professionals and graphic designers. 
The measure of the degree of utilization of highly qualified labour in the Italian labour market we wanted to develop was subject to a number of caveats:

1. It should relate to both the nature of the work and the required knowledge and skills needed to perform it, assessing the extent to which this knowledge and the skills were normally acquirable via HE; it should not relate to personal characteristics of the job post holders such as age, gender, educational qualifications or to the salary levels. References to such dimensions can, in fact, divert our focus from the nature of the jobs we want to analyze to a concern with the economics, social or political dynamics of job allocation, where the qualifications candidates are required to possess in order to be appointed, may reflect credential inflation or cultural capital (Bourdieu and Passeron, 1968) rather than job-related variables;

2. Each category should have clear criteria and boundaries, to minimise coding disagreement and achieve an acceptable level of reliability and comparability with the applications of the same critieria to other national labour forces; it should be easy to develop, without the need for additional data collection, based on national microdata with the highest possible degree of reliability. This is crucial for a measurement that allow us to build time-series indicators with reference to each country.

The choice to build an application of SOC(HE)2010 relevant to the Italian labour force is motivated by its conformity to these criteria. Firstly, the SOC(HE)2010 classification is not vulnerable to accusation that supply and demand fluctuations contribute to allocation of jobs to graduate or non-graduate classification to the extent that SOC(HE)2000 was, whereby oversupply of highly qualified labour changed the qualification profile of previously non-graduate jobs. Secondly, the allocation of each of the 800 Italian job titles to one of the four occupation categories of SOC(HE)2010 (Experts, Orchestrators, Communicators and Non Graduate Jobs) make it consistent with the conceptual basis embodied in ISCO08 and consequently in the Italian Occupational Classification (CP) in which the ranking of professions is established on the basis of their relative skill level and skill specialization. Thirdly, the allocation to 'graduate' and 'non-graduate' categories makes explicit reference to the formal education required to carry out the tasks and duties associated to the concerned job title enabling us to directly assess which jobs require HE to be competently performed. Finally, data from Italian labour force survey (RCFL) and from AlmaLaurea database (a consortium of 64 Italian universities that surveys graduates career paths) are consistent with the above mentioned needs as they are 
easily available, referred to the national dimension and code professions utilizing CP2011 and its predecessors CP2001 and NUP, the CP2001 iterated and modified version issued in 2006.

The procedure followed by Elias and Purcell to allocate each SOC2010 unit group to one of the four categories consisted, as noted above, in a qualitative on-desk assessment based on information contained in SOC2010 classification resulting in a score on a 1-9 point scale. This procedure is not feasible when applying $\mathrm{SOC}(\mathrm{HE})$ to Italian professions as economic, social and cultural differences greatly limit the extent to which job descriptions are transferable across countries. Moreover, Italian occupational classifications contain less information than the UK SOC as they make no reference at all to the formal or informal education workers in a particular job should possess and this fact could limit the extent of agreement when assessing whether the knowledge and skill utilized in the job place were to be acquired through the HE system. We thus developed an allocation strategy which makes direct reference to the skills and competences that the job-holders need to carry out their job. This arguably constitutes a 'purer' variant of the original Elias and Purcell exercise, uncontaminated by the relationship between knowledge, skills and credentials assumed by the UK classifiers and researcher bias ${ }^{8}$. We utilized data from the ISFOL-ISTAT survey on Italian professions mentioned in subparagraph $\S 1.1$ (Gallo et al., 2007).

\subsection{ISFOL-ISTAT survey on Italian professions and variables re-aggregation}

In 2006, a study group composed by members from both ISFOL and ISTAT ran the first survey of Italian professions aiming to assess which skills were utilized in the labour market/workplace and the extent of such utilisation. 16,000 workers were interviewed and asked to assign a score to 255 variables on a 1-100 point scale in terms of complexity of the knowledge, skill or competence associated to the tasks of their particular job. These 255 variables were borrowed from the $\mathrm{O}^{*} \mathrm{Net}^{9}$ taxonomy and covered 7 areas: Knowledge (33

8 Although of course it is susceptible to respondent bias, which might be expected to amplify the extent to which skills are required.

9 O*Net (Occupational Information Network) is an American on-line occupational database designed in the 1990s to organize, describe and spread data on employment, jobs, skills shortages, professional profiles and individual characteristics facilitating the matching of demanded and supplied skills. $\mathrm{O} *$ Net embodies the advantages of SOC classification and the implementation of the system took large account of the indications emerged from the SCAN (Secretary's Commission on Achieving Necessary Skills) works, such as the distinction within the three types (basic, thinking and personal) of soft skills: basic skills (reading, writing, arithmetic, comprehension and expression), thinking skills (creative thinking, problem solving, etc..) and personal qualities (responsibility, sociability, etc...). It is divided into six dimensions: Experience Requirements, Occupation Requirements, Occupation 
questions), Skills (35 questions), Attitudes (52 questions), Values (21 questions), Working styles (16 questions), Generalized working activities (41 questions) and Working conditions (57 questions). Scores were thus aggregated in the seven clusters and an average score was computed for each of the 800 Italian job titles at a 5-digit level in all of these clusters.

We selected the 109 variables contained in the three areas that described knowledge, skills and tasks/competences (Knowledge, Skills and Generalized working activities) and proceeded to disaggregate them. Thus, we allocated each of these 109 variables to one of the three clusters of competence of the SOC(HE)2010: Specialist expertise deriving from HE knowledge (labeled EXP), Orchestration expertise (labeled ORC) and Communication expertise (COM). The results of this aggregation of Knowledge, Skills and Generalized working activities are fully reported in Appendix 1.

\subsection{EQF Level}

By this stage we had some 109 variables with their relative 'complexity score' for each of the 800 job titles. For each profession, we computed a mean of all of these 109 variables. Thus, we selected as 'core variables' only those variables exceeding one standard deviation from this average value.

For instance, for Physical scientists (code 2.1.1.1.1 in the NUP) the threshold of a standard deviation was set at 81.51 and the exceeding selected variables included physics, mathematics, science and mechanics in the EXP cluster; creative thinking and updating and review the relevant knowledge in the ORC cluster; and, finally, reading comprehension, speaking and writing in the COM cluster.

We thus computed the average score for the selected variables in each cluster for each job title. Continuing our example run on Physical scientists (2.1.1.1.1) this meant that the three clusters EXP, ORC and COM measured 91.29, 86.50 and 87.50, respectively.

In order to assess whether these complexity scores represented a skill level acquirable via HE only, we wanted to translate our 1-100 point scale into the 8 levels of the European Qualification Framework $^{10}$, in which Level 6 and Level 7 indicate respectively a university

Specific Information, Occupation Characteristics, Worker Characteristics and Worker Requirements (see Peterson et al., 1999 and IRSO, 2000).

10 The 8 EQF levels are summarized in table A.2 in Appendix 2. 
degree and a Master's degree. We borrowed from ISFOL/ISTAT methodology, which postulate a linear progression in skill levels from EQF Level 2 to EQF Level 7 thus running a simple proportion between the two scales.

EQF levels computed accordingly for Physical scientists (2.1.1.1.1) were 7.30 for the EXP cluster, 6.92 for the STR cluster and 7.00 for the COM cluster.

We established as allocation rule to select the highest of these three score (7.30) to represent the job title (EQF Level 7 = Master's degree) and allocated the profession (Physical scientists) in the occupational category corresponding to its relative cluster (Experts).

Table 2.1 EQF Levels and Occupational category for Physical scientists (2.1.1.1.1) according to SOC(HE)-Italy

\begin{tabular}{ccccccc}
\hline \hline $\begin{array}{c}\text { NUP } \\
\text { Code }\end{array}$ & Job Title & $\begin{array}{c}\text { Experts } \\
\text { EQF }\end{array}$ & $\begin{array}{c}\text { Orchestrat } \\
\text { ors EQF }\end{array}$ & $\begin{array}{c}\text { Communicators } \\
\text { EQF }\end{array}$ & $\begin{array}{c}\text { Highest EQF } \\
\text { Score }\end{array}$ & $\begin{array}{c}\text { Major } \\
\text { Group }\end{array}$ \\
\hline 2.1.1.1.1 & Physical scientists & 7.30 & 6.92 & 7.00 & $\begin{array}{c}\text { Experts (7.30 } \\
\text { EQF Level 7) }\end{array}$ & EXP \\
\hline \hline
\end{tabular}

Appendix 3 contains EQF Levels and SOC(HE)-Italy Occupational Category for each 800 Italian job titles as displayed in the example in Table 2.1. Not all Italian job titles have a corresponding score in all of the three clusters. In fact, for some professions there could be no variables exceeding the standard deviation for a given cluster: Dental technicians (3.2.1.3.2), for instance, do not have a score for the COM cluster.

\subsection{Validation on RCFL data and AlmaLaurea survey data}

Validating a measure consists in testing whether it is consistent with other measures of the same phenomenon (construct validation) and whether its conceptual basis has been appropriately applied (criterion validation). These tests reflect directly properties listed in subparagraph $§ 1.1$.

Given that the application of SOC(HE)-Italy requires occupation information contained in official classifications we relied on two data sources in which the NUP (the iterated and modified version of CP2001) were utilized: the ISTAT survey on Italian labour force (RCFL) and the AlmaLaurea survey on graduates' occupations (AL). RCFL survey is run by ISTAT 
continuously on 250,000 families (more than 600,000 individuals) settled in 1,100 Italian municipalities. RCFL collected occupational information from the resulting stratified sample utilizing CP2001 and NUP in all quarters between 2004 and 2010. For our purposes, individuals in the sample were relevant only if employed and with a valid occupational code and this restricted the sample to 58,190 respondents: 34,156 males and 24,034 females. Although there are available data concerning more recent quarters (from 2011 to 2013) our choice is to test our measure on the period 2004-2010 in order to evaluate structural change that occurred soon before and after the financial crisis that took place in 2008. Moreover, data collected in quarters from 2011 to 2013 utilized the new CP iteration (CP2011) instead of the NUP, the classification on which ISFOL and ISTAT run their survey on professions in 2006. On the other hand, AlmaLaurea is a consortium of Italian universities that analyses graduates' career paths interviewing them at the time of graduation ${ }^{11}$ and then one, three and five years later. In our analyses we consequently refer to the last cohort whose information is fully available; the cohort of individuals who graduated in 2007. The population is composed of those who earned either a Master's degree or a five/six-year university degree, such as Law and Medicine respectively, and responded to all of the survey waves up to 2012. This consists in 31,162 graduates from 46 Italian universities. Restricting our sample to relevant respondents (employed individuals with a valid occupation code) we investigated 18,269 graduates.

\section{a. Construct validation}

To test the construction of SOC(HE)-Italy we assessed the extent to which workers employed in professions which we ranked as graduate jobs (Experts, Orchestrators and Communicators) appeared to have achieved an earnings premium compared to those in non-graduate jobs. The rationale of this test is to compare two alternative definitions of graduate job: a job for which workers must have knowledge and skills imparted via HE (the conceptual basis of our measure) versus a job in which graduates appear to have been rewarded for their higher human capital endowment.

\footnotetext{
${ }^{11}$ The AlmaLaurea sample we utilize in this study is composed of graduates who earned an Italian Master's Degree, with no reference at all to those who completed an undergraduate three-year course without proceeding further in their studies. In fact, in the early 2000s the Italian Higher Education system was reformed according to the so called "Bologna Process". The reform was termed " $3+2$ " and based on a two-cycle degree structure: a first-level three-year undergraduate course plus a second-level two-year Master's Degree. As a consequence, by mentioning 'graduates' and 'graduation' in this paper we mean, respectively, students who earned a Master's Degree and the relative educational attainment.
} 
Figure 2.1 Mean gross monthly pay for SOC(HE)-Italy groups (Source: ISTAT RCFL data, April 2010 - June 2010)

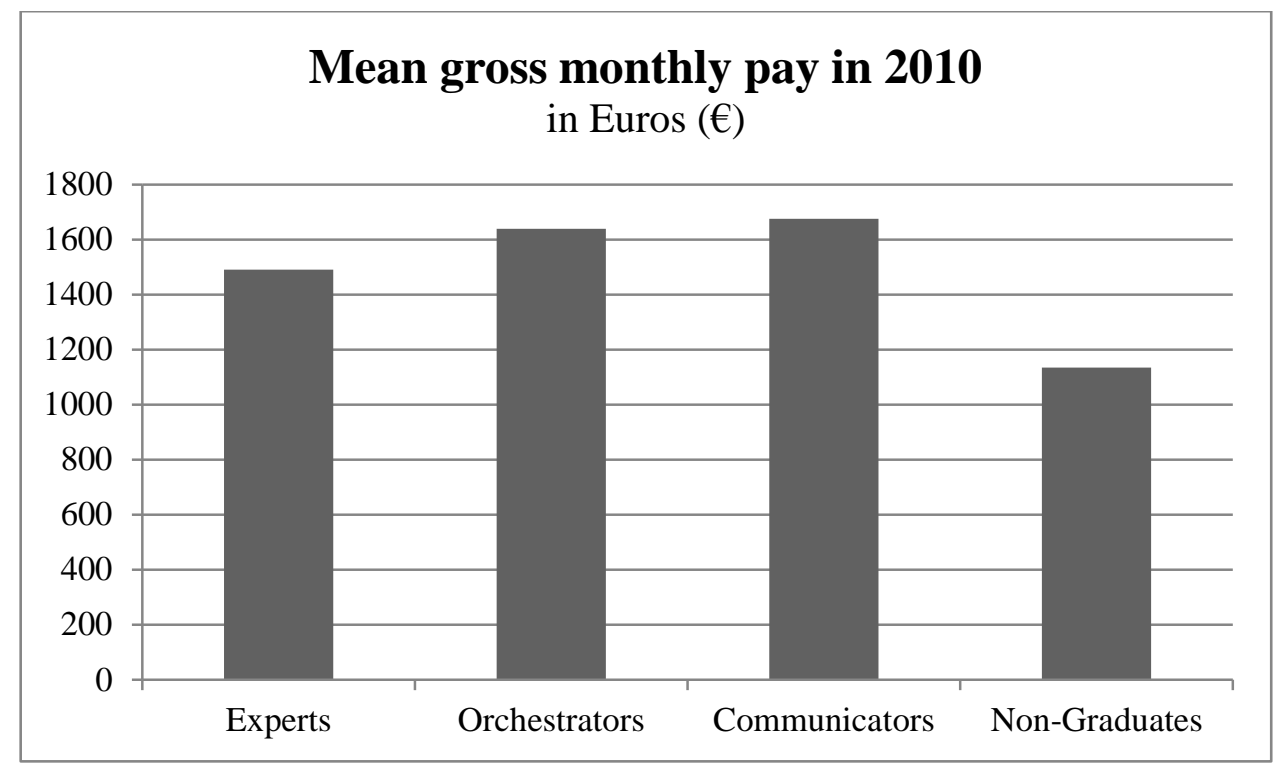

On average, workers employed in one of the three graduate jobs categories earned 1,602€ per month compared to $1,135 €$ earned by those employed in the non-graduate group. Communicators appeared to achieve the highest earnings (1,676€ mean gross pay per month): apparently $48 \%$ more than non-graduate occupations, Experts achieved least with an average of 1,491€: a premium of $31 \%$. Finally, Orchestrators earned $44 \%$ more than those employed in non-graduate occupations (1639€ on average).

To test whether these differences in means were statistically significant we estimated two specifications of a semi logarithmic wage equation model in which the natural logarithm of the gross monthly pay (lnW) relates to being employed in one of the four groups (Experts, Orchestrators and Non-graduates). Specification (2) in Table 2.3 includes additional controls (gender, age, job tenure, economic sector and territorial district) omitted in specification (1) ${ }^{12}$. Both specifications include dummy variables for being employed in Experts, Orchestrators and Communicators, omitting the dummy variable for Non-graduates occupations which are thus adopted as benchmark.

12 For complete model and variables descriptions see Appendix 4. 
Table 2.2 Earning premia in 2010 for Experts, Orchestrators and Communicators (source: our elaborations on ISTAT RCFL data April 2010 - June 2010, controls omitted in table, see Appendix 4)

\begin{tabular}{lccc}
\hline \hline & $(1)$ & $(2)$ & $(3)$ \\
& $\ln \mathrm{W}$ & $\ln \mathrm{W}$ & $\ln \mathrm{W}$ \\
\hline Experts & $0.2884 * * *$ & $0.2082^{* * *}$ & $0.1756^{* * *}$ \\
& $(0.0052)$ & $(0.0043)$ & $(0.0043)$ \\
& & & \\
Orchestrators & $0.3475^{* * *}$ & $0.2858^{* * *}$ & $0.2590^{* * *}$ \\
& $(0.0241)$ & $(0.0202)$ & $(0.0201)$ \\
& & & \\
Communicators & $0.4010^{* * *}$ & $0.2535 * * *$ & $0.1699 * * *$ \\
& $(0.0069)$ & $(0.0061)$ & $(0.0066)$ \\
Degree Holders & & & $0.1835^{* * *}$ \\
& & & $(0.0055)$ \\
\hline$N$ & 42720 & 42720 & 42720 \\
$R^{2}$ & 0.108 & 0.479 & 0.495 \\
adj. $R^{2}$ & 0.1082 & 0.4786 & 0.4943 \\
\hline \hline Standard errors in parentheses; $* p<0.10, * * p<0.05, * * * p<0.01 ;$ Omitted variable: Non-graduates jobs
\end{tabular}

Earnings premia are significant and range from $28.84 \%$ to $40.10 \%$ in specification (1) where only dummy variables associated with the SOC(HE)-Italy groups are included in the regression model and decrease to $20.82 \%-28.58 \%$ when adding further controls in specification $(2)^{13}$. We can conclude that there is a relationship between pay and the high levels of knowledge and skills encompassed in the SOC(HE)-Italy occupational groups for graduate jobs. In other words, our definition is consistent with the alternative definition of graduate job and the construct is valid. Furthermore, it is worth noting how Orchestrators earned the highest premium after controls, reflecting the higher wages for Communicators in specification (1) attributable to other individual (age, gender, work experience) or job (economic sector and territorial district) characteristics. In addition, when including a dummy variable for holding a degree in specification (3) we are able to consider differences between the different occupational categories over and above individuals' educational attainments. In this case,

13 Regressors associated with dummy variables representing employment in one of the four occupational groups, given the semi logarithmic nature of the model, are to be interpreted as the percentage variation of the gross monthly pay as consequence of being employed in such occupational groups. The dummy variable associated to being employed in non-graduate jobs (NONG) is omitted in both specifications for collinearity reasons. Thus, parameters associated with Experts, Orchestrators and Communicators come to represent the average percentage difference between their gross monthly pay and the mean gross monthly pay of workers employed in nongraduate jobs. 
Communicators show the lowest average earning premium of all graduate professions. This fact is consistent with empirical evidence from AlmaLaurea data on mean net monthly pay, which shows that Communicators earned, on average, less than any other occupational group (and also consistent with the analyses conducted by Elias and Purcell of recent UK graduates who entered the labour market in 2009-10). In the workforce as a whole, the distribution of orchestrators is skewed towards the upper age ranges, whereas that of Communicators to the lower end, whereas the distribution of Experts comes closer to that of the labour market as a whole.

Figure 2.2 Mean net monthly pay for SOC(HE)-Italy groups (Source: our elaborations on AL data)

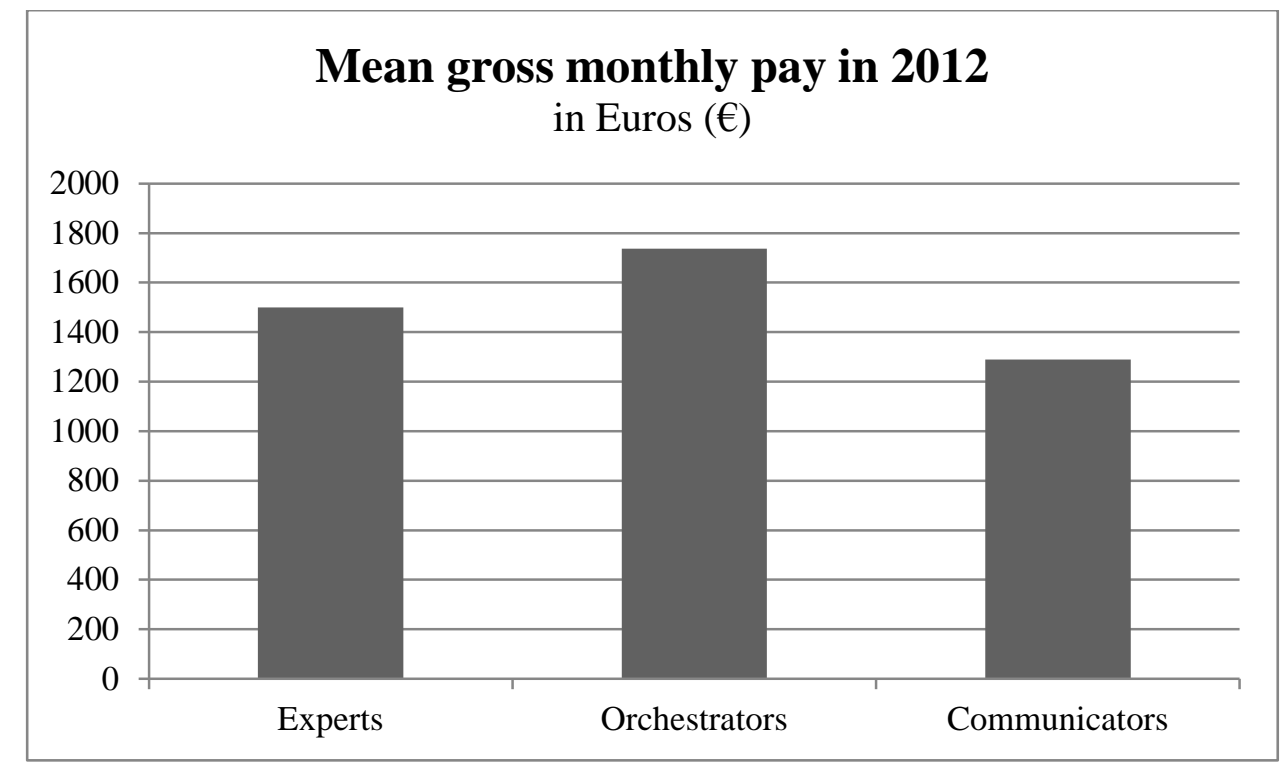

\section{b. Criterion validation}

AlmaLaurea (AL) data are also important when validating the criteria of SOC(HE)-Italy. Questionnaires utilized in AL survey include at least three questions explicitly linked to the conceptual basis of the classification. These are question A16 ("Do you make use of the skills acquired in your Master's degree course in your current job?"), A17 (“Is the Master's degree you hold required for your current job?") and A17LS (“Are knowledge and skills acquired during your Master's degree course useful to competently perform your current job?"). 
Table 2.3 Responses to question A16 aggregated by SOC(HE)-Italy groups (source: our elaborations on AL 2012 survey data)

\begin{tabular}{lcccc}
\hline \hline \multirow{4}{*}{ A16 "Do you make use of the skills acquired in you Master's degree course in your current job?" } \\
\cline { 2 - 5 } & Experts & Orchestrators & Communicators & Non-Graduates \\
\hline Yes, a lot & 74 & 46 & 69,5 & 48,7 \\
Yes, a bit & 19,6 & 42,7 & 21,6 & 33,5 \\
Not at all & 6,4 & 11,3 & 8,9 & 17,8 \\
\hline \hline
\end{tabular}

As shown in Table 2.3, the graduates in AL survey who were allocated to the three graduate job groupings of the SOC(HE) stated that they were making use of the skills acquired via HE in the $91 \%$ of cases on average, ranging from $88.7 \%$ (Orchestrators) to $93.6 \%$ (Experts). This result is well above the corresponding outcome for those employed in non-graduate jobs (82.2\%), among which almost one in five complained about the poor utilization of his/her skills in the workplace (17.8\%). These findings are reinforced by evidence from Table 2.4 that summarizes respondents' self-assessment on the appropriateness of their Master's degree with respect to their current job.

Table 2.4 Responses to question A17 aggregated by SOC(HE)-Italy groups (source: our elaborations on AL 2012 survey data)

\begin{tabular}{lcccc}
\hline \hline \multicolumn{2}{c}{ A17 "Is the Master's degree you hold required for your current job?" } & \\
\cline { 2 - 5 } & Experts & Orchestrators & Communicators & Non-Graduates \\
\hline Yes, it is legally required to be hired & 55,4 & 13,9 & 50,5 & 24,6 \\
It isn't legally required but in fact it is & 16,8 & 25,1 & 11,6 & 18,5 \\
It is not required but still it is useful & 22,8 & 52,7 & 30,2 & 42,9 \\
It is neither required nor useful & 4,9 & 8,2 & 7,6 & 13,9 \\
\hline \hline
\end{tabular}

When focusing on qualification requirements, the gap between graduate and non-graduate jobs is even larger when considering the difference in means. Individuals employed in the NonGraduate group stated their educational qualification were required, legally or actually, in only $43 \%$ of cases, compared to the higher average propensity (58\%) in the other three groups. Not surprisingly, there is a vast gradient in terms of responses between different graduate groups as only $39 \%$ of Orchestrators tend to consider their qualification as needed for their current job. This share is even lower than that recorded for Non-graduates and this could be due to the fact that professions dealing with 'orchestration expertise' have only recently started to employ graduates, being the relative hiring standards oriented more towards working experience than to 
formal education, as above argued. On the other hand, this group has the highest share of workers considering a Master's degree as useful on the job, with only $8 \%$ stating to be not requiring or using their skills, compared to $14 \%$ of those in Non-graduate jobs.

Table 2.5 Responses to question A17LS aggregated by SOC(HE)-Italy groups (source: our elaborations on AL 2012 survey data)

\begin{tabular}{lcccc}
\hline \hline A17LS “Are knowledge and skills acquired during your Master's degree course useful to competently perform your \\
\cline { 2 - 5 } & Eurrent job?" & & \\
\cline { 2 - 5 } & Experts & Orchestrators & Communicators & $\begin{array}{c}\text { Non- } \\
\text { Graduates }\end{array}$ \\
\hline $\begin{array}{l}\text { Having a Master's degree is fundamental } \\
\text { to carrying out my job }\end{array}$ & 31,3 & 16 & 17,4 & 17,8 \\
$\begin{array}{l}\text { Having a Master's degree is useful in } \\
\text { carrying out my job }\end{array}$ & 47,1 & 56,3 & 50,7 & 44,9 \\
$\begin{array}{l}\text { An undergraduate course would be } \\
\text { sufficient preparation to carrying out my } \\
\text { job }\end{array}$ & 16 & 18,9 & 21,4 & 21,2 \\
$\begin{array}{l}\text { To perform my job secondary education } \\
\text { qualifications are sufficient }\end{array}$ & 5,4 & 8,7 & 10,2 & 16,2 \\
\hline \hline
\end{tabular}

When reference is made to both knowledge and skills, all of the three 'graduate jobs' groups report low proportions of workers stating they are underutilizing knowledge and skills acquired during HE (equal to or below 10\%) while those in 'non-graduate' occupations report one out of six workers in such situation. All in all, graduates surveyed by AlmaLaurea who were employed in SOC(HE)-Italy 'graduate occupation' groups, report a higher propensity to utilize skills acquired in HE, to be hired in more demanding and better paying jobs than those in the 'non-graduate' category and, finally, are less likely to be under-employed five years after graduation. Together, these findings constitute a consistent endorsement of the classification.

\section{Labor market trends: the evolution of the Italian occupational structure measured with $\operatorname{SOC}(\mathrm{HE})$-Italy}

Having established that SOC(HE)-Italy provides a valid measure of the utilization in the labour market of knowledge and skills mainly imparted via HE and that it may be relied upon to 
distinguish and classify graduate and non-graduate jobs, it is applied to the Italian labour force to assess its structural trends. Before doing this, it is useful to describe recent trends for both employment and unemployment. Figure. 3.1 shows, in thousands, the total employment and the total unemployment between 2004 and 2010. It is noticeable how total unemployment reaches its minimum and starts increasing in 2007 , one year before the total employment reaches its peak. This can be explained by a significant increase in the total active population with new entrants experiencing difficulties finding a first job, as highlighted by CNEL (2012).

Figure 3.1 Total employment and total unemployment between 2004 and 2010, in thousands (Source: our elaborations on ISTAT data)

\section{Total employment}

(thousands; seasonally adjusted)

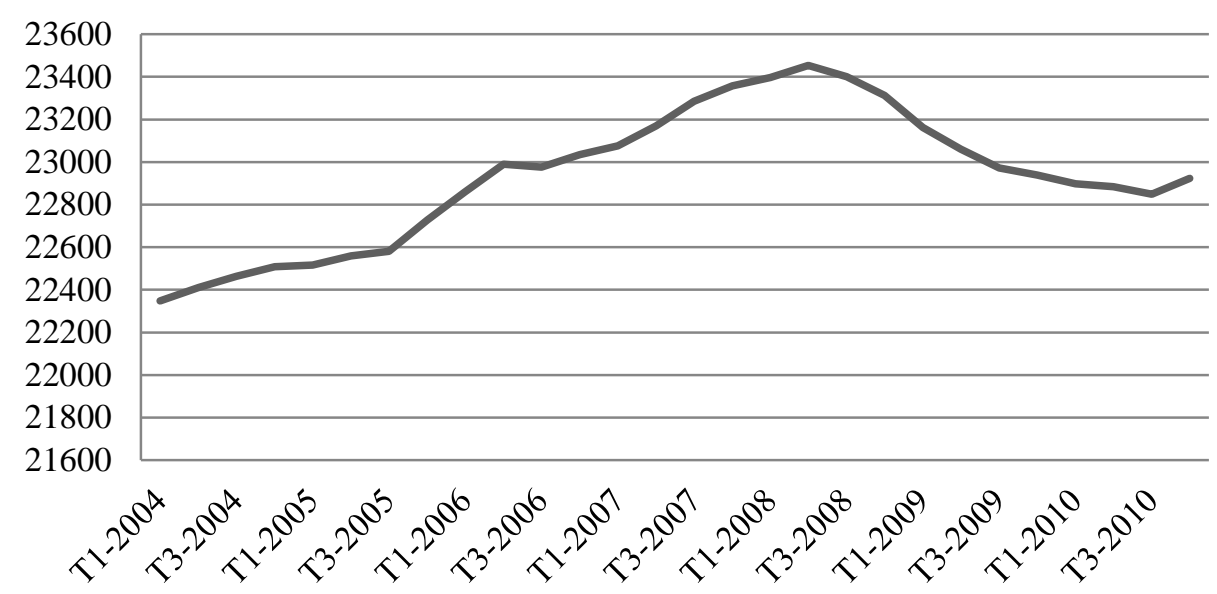

Total unemployment

(thousands; seasonally adjusted)

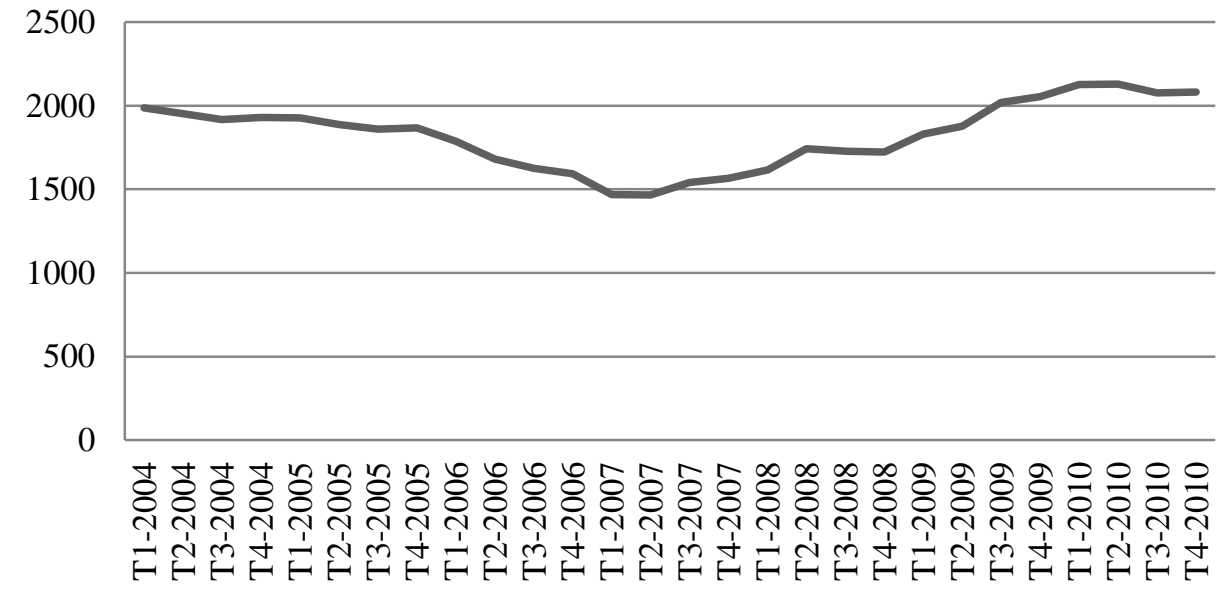


Figure. 3.2 shows employment and unemployment by gender. Female workers seem to have performed better than men soon after the crisis by increasing rather than decreasing both their participation in the labour market and the total numbers in employment. Moreover, females unemployment increased at a lower rate than that of men since 2007, leading to a dramatic overtaking between the end of 2008 and the beginning of 2009. This has been termed "the additional worker phenomen" by CNEL (2012), pointing out how the recession has forced many previously inactive women to enter the labour market because of the worsening budget constraints of their relative households ${ }^{14}$.

Figure 3.2 Employment and unemployment by gender between 2004 and 2010, thousands (Source: our elaborations on ISTAT data)

\section{Employment by gender}

(thousands; seasonally adjusted)

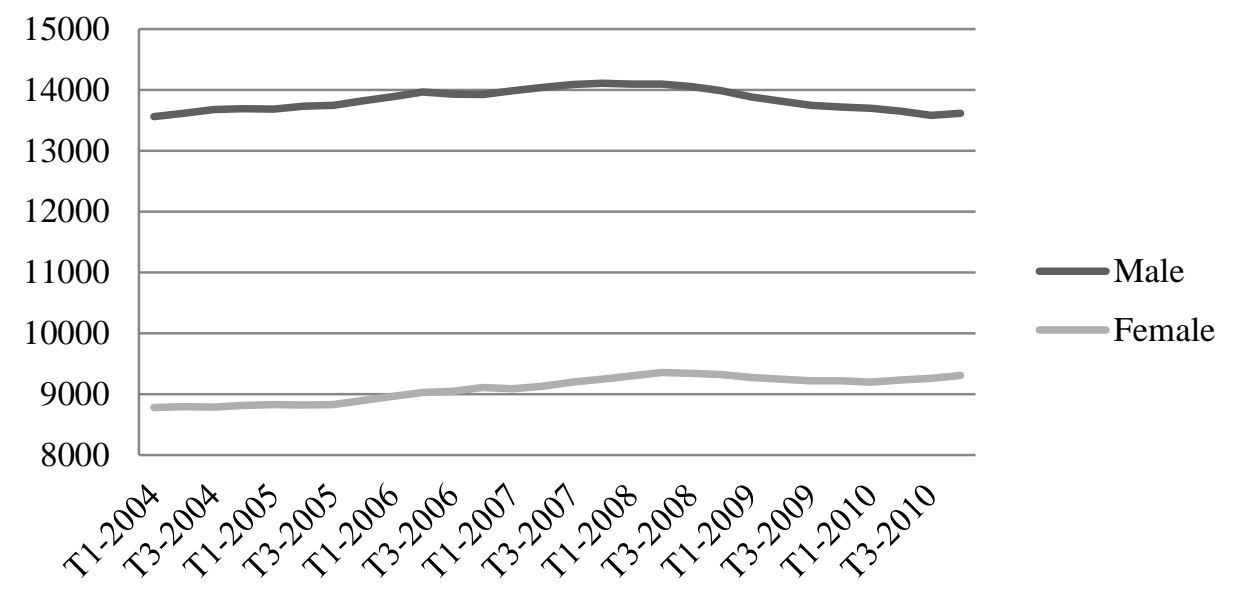

14 This is especially true in the south of Italy, where the participation of women in the labour market has always been poor. 


\section{Unemployment by gender}

(thousands; seasonally adjusted)

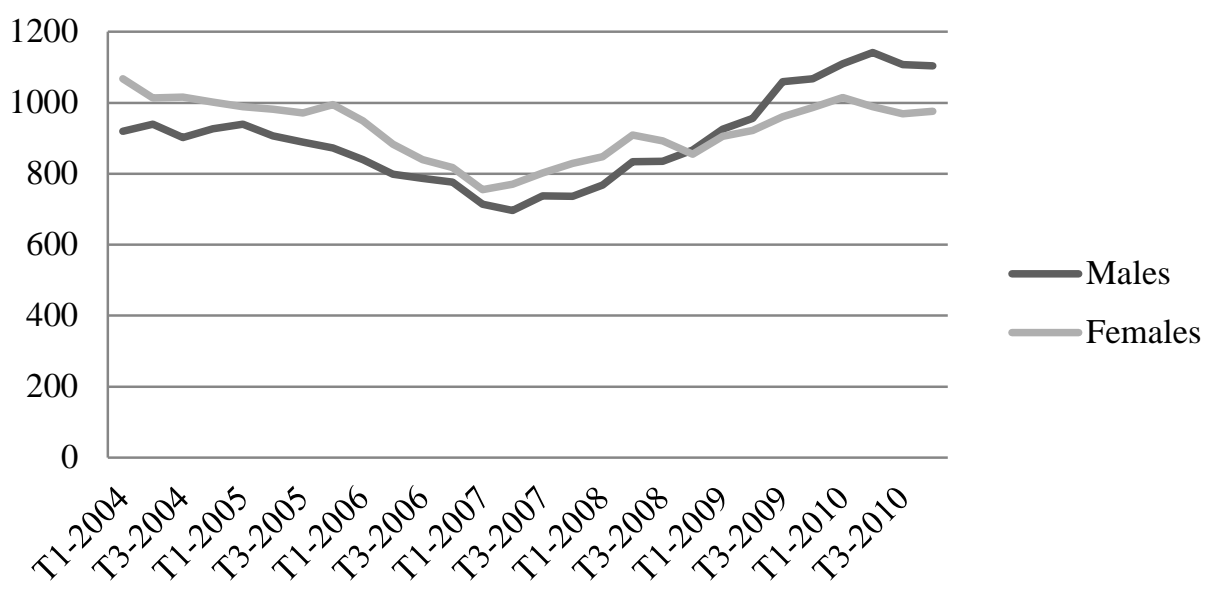

Table 3.1 shows percentages of the four occupational categories in the years from 2004 to 2010. Graduate jobs tend to have increased their relative share up until 2007 when a break takes place: from this peak (32.72\%) graduate jobs as defined by SOC(HE)-Italy decrease until the end of the period where they come to represent a share of the labour force which is more or less equal to its starting value (29\%). This trend is consistent to a certain degree with previous studies that employed different definitions of 'graduate jobs', such as the reports issued by CNEL (2012) and AlmaLaurea (2012). But still there are two significant differences. First: the SOC(HE)-Italy measurement for graduate occupations lies between the two. This is reassuring if we assume that estimates by CNEL and AlmaLaurea were respectively upward and downward biased, given that they ranged between $34 \%-37 \%$ and $17 \%-19 \%$. Nonetheless, CNEL and AlmaLaurea based their measures on NUP classification as we did but in these cases the NUP was not deconstructed, with their component criteria disaggregated as we have done above. NUP occupational groups were taken per se as a proxy for the utilization of skills and labelled as 'high', 'medium' and 'low' skilled professions. As occupational groups in the NUP do not account for formal education only (as argued in subparagraph §1.1) but also for work experience and other job characteristics, we can conclude that CNEL and AlmaLaurea actually measured something different from what we did. Second: when comparing the three time-series built onto SOC(HE), CNEL and AlmaLaurea indicators it is worth noting that the first two reach their peaks in 2007 while AL reaches its peak in 2008. In other words, our measure reinforces the evidence highlighted by CNEL (2012) that the downturn in the Italian graduate labour market preceded the financial crisis that took place in 2008. The recession exacerbated an already declining demand for graduates and although early signs of recovery showed some subsequent increase in demand in 2011-12 (Bank of Italy, 2013), it seems 
unlikely that the graduate over supply will be absorbed into appropriate employment in the medium term without substantial economic restructuring. Similar findings from analysis of recent UK labour market trends (Purcell and Elias 2014) reinforce this.

Figure 3.3 Evolution of Italian occupational structure by SOC(HE)-Italy groups (2004-2010) (source: our elaborations on ISTAT RCFL data)

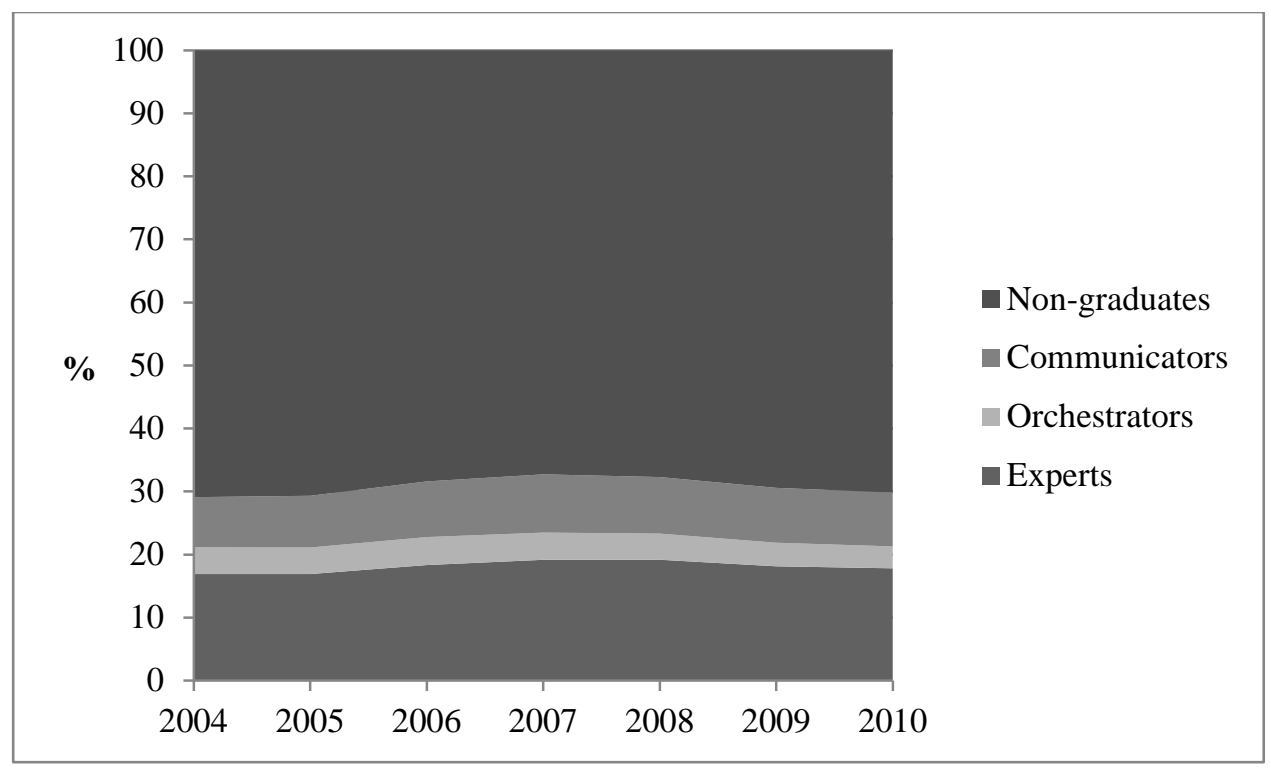

Table 3.1 Occupational structure by SOC(HE)-Italy, 2004-2010 (Source: our elaborations on ISTAT RCFL data)

\begin{tabular}{lrrrrrrr}
\hline \hline$\%$ & 2004 & 2005 & 2006 & 2007 & 2008 & 2009 & 2010 \\
\hline Experts & 16,9 & 16,9 & 18,33 & 19,16 & 19,17 & 18,13 & 17,81 \\
Orchestrators & 4,24 & 4,22 & 4,44 & 4,32 & 4,15 & 3,74 & 3,48 \\
Communicators & 7,96 & 8,2 & 8,83 & 9,24 & 8,97 & 8,71 & 8,54 \\
Non-graduates & 70,9 & 70,68 & 68,4 & 67,28 & 67,71 & 69,42 & 70,17 \\
\hline Total & 100 & 100 & 100 & 100 & 100 & 100 & 100 \\
\hline \hline
\end{tabular}

By disaggregating the graduate jobs into Experts, Orchestrators and Communicators it can be shown, not surprisingly, that Experts are the biggest graduate group and possibly the major group responsible for both the increase pre 2007 (from 17\% to 19\%) and the decrease that took place afterwards (from 19\% to 18\%). Orchestrators remained virtually unaltered up to 2008 then decreased to their minimum at the end of the period (3\%). Communicators were the first to reach their peak in 2007 (9\%) and the first to decline in the following year, anticipating the 
decreasing demand for the other two groups. When comparing these three groups by age (Figure. 3.2), it is noticeable how the Expert group has a higher proportion of workers belonging to the youngest age group (25-34) than the other two graduate job groupings. This result is important as it shows how the occupational group (Expert) that lost most jobs after the peak was the group most accessible to young people. This reveals that new graduates experienced difficulties entering the labour market as the set of professions in which they were traditionally hired went through a period of stagnation (2004-2010) while the share of workers holding a degree on the total labour force increased from $14 \%$ to $17 \%$ in the period 2004 2011(source: CNEL, 2012).

Figure 3.4 SOC(HE) groups by age in 2010 (source: our elaborations on ISTAT RCFL data, April 2010 - June 2010)

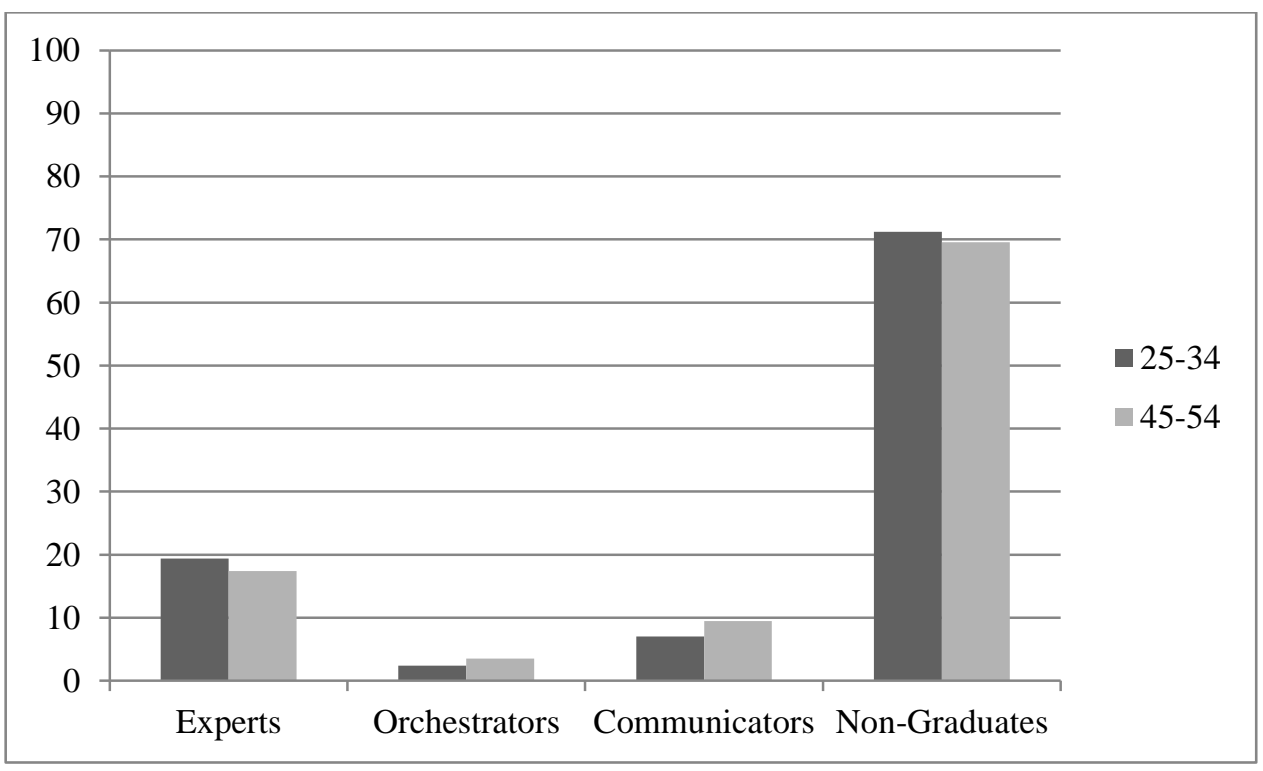

An additional source of concern with respect to young graduates entering the labour market comes from the proportion of young workers employed in Non-graduate SOC(HE)-Italy group. More than two out of three workers aged between 25 and 34 years old were employed in such jobs and this propensity was even higher than that of the age group 45-54 in which the share of those holding a degree was lower.

Figure 3.3 shows the proportion of employees in occupation by SOC(HE)-Italy by gender. Communicators is the only occupational category with a higher proportion of female than male 
employees. Significantly, this category recorded at the end of the period a higher occupation rate (9\%) compared to that in 2004 (8\%), as Experts did (18\% and 17\%, respectively). However, in this last case the proportion of female employees was almost equal to that of males, suggesting that male graduates' employment rate has decreased to a relatively greater extent than that of their female counterparts. In fact, female graduates were less likely to be in Non-graduate jobs and more likely to be employed as Communicators. This last observation could be attributable to the high proportions of females traditionally employed in primary and secondary education (see Appendix 3 for the allocation of these professions in Communicators group).

Figure 3.5 SOC(HE) groups by gender in 2010 (source: our elaborations on ISTAT RCFL data)

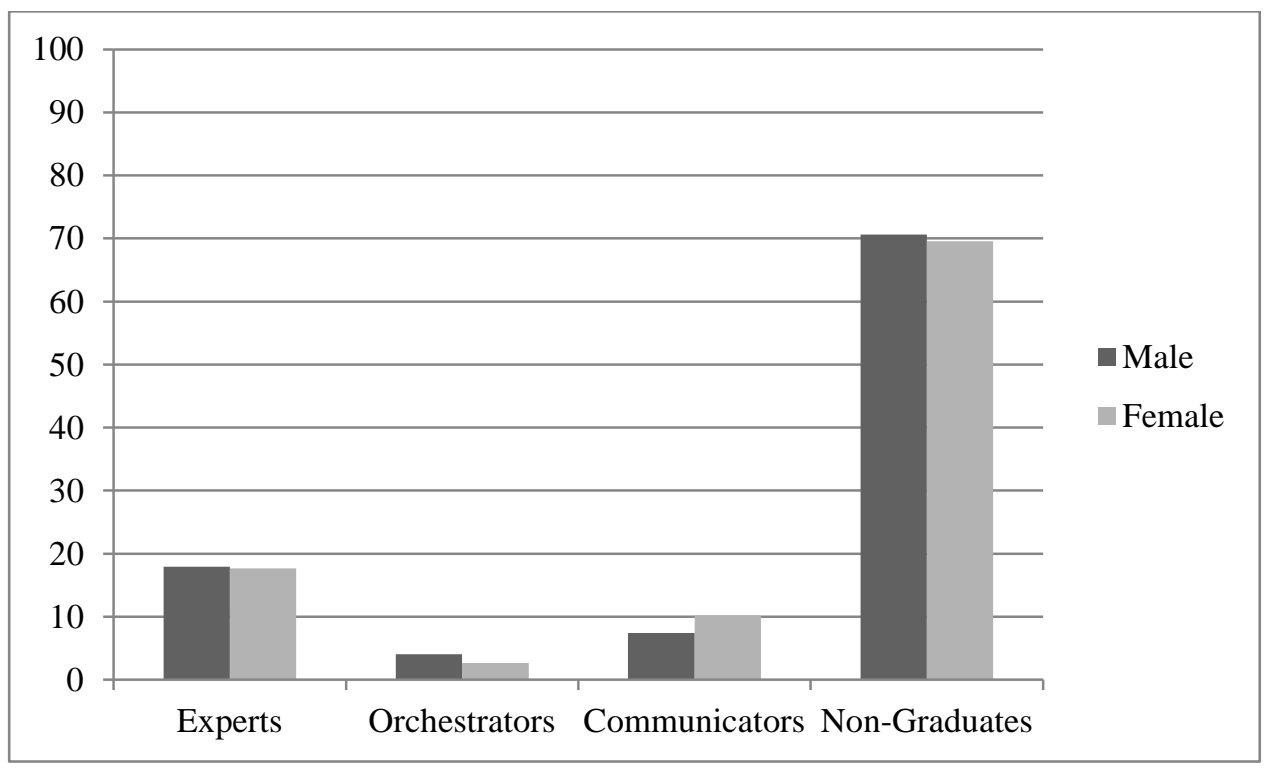

\section{Transnational comparability}

SOC(HE)-Italy has essentially the same conceptual basis as the UK SOC(HE)2010, the same four occupational groups and the same three clusters of competence upon which these are drawn. Nonetheless, the two measures are based on significantly different sources, which may limit the extent to which their respective findings can be compared. The Italian measure can be described as mixed-methods assessment in which both the workers' self-assessment and occupational information resulting from official classifications play a role. On the other hand, the UK classification is based wholly on systematic qualitative assessment of officially- 
constructed job-evaluations based on workers' accounts of what they were required to do in the course of their jobs and the qualifications they needed. Some very similar jobs (like managers in manufacturing and construction) have been allocated to different groups when comparing Italy and the UK. It is not clear to what extent these differences are attributable to the different technical processes through which the two measures have been built or, on the other hand, whether jobs are differently constructed or the divisions of labour among jobs vary in the different national contexts. In the case of directors and managers in manufacturing (SOC code 1122; NUP code 1.2.1.2.0 and 1.2.2.1.0) and construction (SOC 1123; NUP 1.2.1.3.0 and 1.2.2.2.0), these are classified as Orchestrators in the original SOC(HE) and as Experts in SOC(HE)-Italy ${ }^{15}$. This different allocation might be explained by reference to differences in the two classifications and to the higher level of bureaucracy and complexity in the Italian legal and tax system. This complexity would require individuals running big businesses to have better understanding of and a higher confidence with these dimensions in spite of the ability to manipulate and coordinate the activities and knowledge. Moreover, Italian managers might be predominantly hired or promoted to senior posts on the basis of their relative work experience rather than looking at formal educational credentials.

Table 3.2 Key indicators on SMEs in the non-financial business economy, 2005 (Source: Eurostat, 2008)

\begin{tabular}{|c|c|c|c|c|c|c|}
\hline & \multirow[b]{2}{*}{$\begin{array}{l}\text { Number of } \\
\text { enterprises } \\
\text { (thousands) }\end{array}$} & \multirow[b]{2}{*}{$\begin{array}{l}\text { Number of } \\
\text { persons } \\
\text { employed } \\
\text { (thousands) }\end{array}$} & \multirow[b]{2}{*}{$\begin{array}{c}\text { Value added } \\
\text { (EUR } \\
\text { billion) }\end{array}$} & \multicolumn{3}{|c|}{ (\% share of SMEs in national total) } \\
\hline & & & & $\begin{array}{l}\text { Number of } \\
\text { enterprises }\end{array}$ & $\begin{array}{l}\text { Number of } \\
\text { persons } \\
\text { employed }\end{array}$ & Value added \\
\hline EU-27 & 19.602 & 85.000 & 3.090 & 99,8 & 67,1 & 57,6 \\
\hline IT & 3.819 & 12.182 & 420 & 99,9 & 81,3 & 70,9 \\
\hline UK & 1.535 & 9.636 & 501 & 99,6 & 54,0 & 51,0 \\
\hline
\end{tabular}

On the other hand, the analysis we make with SOC(HE)-Italy and the analysis made by Elias and Purcell (2013) highlight similar findings and the few differences in these findings are consistent with already known structural differences among the two countries. First, Nongraduate jobs are substantially the majority in both national labour forces. Italy has a higher

15 More precisely, Italian NUP distinguishes between directors and managers. This is why there are 4 Italian codes associated to just two British ones. Three out of four codes have been allocated in the Experts group (managers in manufacturing and directors and managers in construction), while the remaining one (directors in manufacturing) are allocated to the Orchestrators group. I could explain this, ; ;go on then! 
proportion of workers employed in these jobs (70\% against 60\%), consistently with preexisting evidence from AlmaLaurea (2012). Second, the Experts group employed comparable shares of employees (18\% and 20\%) on the total labour force. Third, the Orchestrators group was significantly bigger in the UK (12\%) compared to the corresponding Italian group (4\% on average between 2004 and 2010). This is not surprising given the reported higher proportion of employees employed in managerial occupations in the UK compared to other EU countries and the higher tendency of British workers compared to any other EU nationality to report they are employed in such jobs (Elias and McKnight, 2001). Additionally, it is worth noting how Italy and the UK differ greatly in terms of both industries and firms size: as Table 3.2 shows, more than $80 \%$ of the Italian labour force is employed in SMEs while this proportion in the UK is just over the $50 \%$. The two shares are respectively well over and well under the EU mean value, which makes the difference between the two even more remarkable. Italian SMEs are often family based and might be less likely to hire employees to managerial occupations. Finally, Orchestrators are rewarded with the highest earning premium in both Italy and the UK, although graduate earnings premia in Italy have been significantly lower in Italy (25\% on average) than in the UK (35\% on average). This last evidence reinforces estimates on Italian graduates' earnings using AL data, in which recent graduates working abroad appeared to have enjoyed higher premia than their Italy-based peers (AlmaLaurea, 2012; Cattani, Guidetti and Pedrini, 2014).

\section{Conclusion}

Recent developments in occupational classifications have shifted the focus of the relative conceptual basis from industries and economic sectors to skill levels. The rationale for this has been to provide policy-makers with classifications with the potential to monitor and measure the degree to which investments in national skills development and, in particular, the extent to which knowledge and skills were being required and utilised in 'the knowledge society'. However, the operational definition of skill and skill levels adopted by the ILO do not include much reference to the role or relevance of higher education. This has limited the reliability and validity of such classifications when trying to define and measure the utilization of highly qualified labour in national economies and across different economies. Several attempts have been made to develop new taxonomies either by integrating or substituting existing official classifications, to capture the ongoing changes in the occupational structure concerning the 
utilization of knowledge and skills imparted in HE, which had been expanding, with increasing levels of participation, in virtually all economies.

Among these, Elias and Purcell's SOC(HE) has attracted the interest of both analysts and policy makers in the UK and abroad. We decided to develop an application of this classification for the Italian labour force because its conceptual basis is fully consistent with our purpose to better understand these structural changes. Moreover, SOC(HE) has a number of compelling characteristics: it is easy to build as it is based on official classifications and does not require additional time-consuming data entry; it allows for the construction of time-series indicators with which it is possible to assess trends over periods of economic change; having been already applied in another European country it facilitates, to a certain extent, comparisons between recent employment trends in the UK and Italy. In order to allocate each of the 800 Italian job categories into 'graduate' and 'non-graduate' groups, we attached three EQF levels to them, borrowing from the methodology followed by ISFOL/ISTAT in their 2006 survey on Italian professions. These three EQF levels represented the formal education level required in each of the SOC(HE) constituent clusters of experience to carry out a particular job. The highest of these three was then taken to be most representative of the knowledge and skills that were axiomatic to being able to accomplish the tasks and duties associated to that job, and determined its allocation into one of the three graduate jobs groupings: Experts, Orchestrators and Communicators.

After having validated SOC(HE)-Italy on RCFL and AL data, we mapped Italian Labour Force survey data from 2004 to 2010 and assessed change over the period, notably two major trends: the increase in the share of those employment in highly-skilled professions up to 2007 and the decrease of this share subsequently. Highly skilled job as defined by SOC(HE)-Italy employed, throughout all the years of the period, a share of the total labour force that differed significantly from pre-existing studies on the topic. To be precise, the SOC(HE)-Italy measure lies between the upper boundary represented by CNEL estimates and the lower boundary marked by AL estimates. The observation of poor performance after the recession that followed the financial crisis in 2008 is consistent with pre-existing work on Italian labour force and graduates' career paths.

The novelty of this analysis consists in highlighting how the share of workers employed in graduate jobs (i.e. the demand for graduate labour) began to decline in the same year that the recession started, in 2008, while the participation ration of one graduate group (Orchestrators) anticipated this decline in 2007. This is in contradiction to some previous analyses, according 
to which this decline begun only in 2009 as direct consequence of the economic downturn. It is not clear, however, to what extent the recession has accelerated changes that would have occurred anyway, or hampered future graduate labour market expansion. There is no doubt that austerity measures adopted by successive Italian governments (such as the headcount freeze started in 2009 for public administrations, schools and universities) have directly affected graduates' labour market entry options by restricting access to traditional sources of employment for young Italian graduates. On the other hand, the decreasing demand for graduate workers in the Italian labour market has been exacerbated by the recession and it seems unlikely that the oversupply of qualified workers can be easily absorbed without substantial economic restructuring capable of to support the upgrading of the Italian districts.

Comparisons between the UK and Italy must be regarded as indicative rather than statistically robust, given that the two utilized measures are based on somewhat different source data. However, the analysis of the Italian labour force produced relatively similar patterns of graduate labour market distribution and change to those observed in the UK labour force over the same period (Purcell and Elias 2014). All in all, we conclude that these two measures allow us to make consistent and more reliable qualitative comparisons between the two countries than has hitherto been possible using existing occupational classifications. Their use, separately and for comparative purposes, advances our understanding of change in demand for knowledge and skills, both nationally and internationally. 


\section{References}

Banca d'Italia (2013) Economic Bulletin No. 67, Bank of Italy, Rome.

Basant, R. and Mukhopadhyay, P. (2009) An arrested virtuous circle? Higher education and hitech industries in Indi, AhmedabadIndian Institute of Management working paper n. 2009-0501.

Brown, P.; Lauder, H.; Ashton, D. (2011) The Global Auction, Oxford University Press, Oxford.

Brown, P., Lauder, H., and D.Ashton (2008) 'Education, Globalisation and the future of the Knowledge Economy', European Educational Research Journal, Vol.7, No.2:131-147.

Cattani, L.; Guidetti, G.; Pedrini, G. (2014) Assessing the incidence and wage effects of overeducation among Italian graduates using a new measure for educational requirements, Working Papers wp939, Dipartimento Scienze Economiche, Universita' di Bologna.

Comin, A.; Barbosa, R. (2011) 'From work to school: higher education and occupational change in Brazil'. Working Paper for ESRC Pathfinder project 'Assessing the impact of higher education expansion on economic restructuring, occupational change and access to opportunities in Brazil and India'.

Consorzio Interuniversitario Almalaurea (2012) Condizione occupazionale dei laureati XIV indagine, Il Mulino, Bologna.

CNEL (2012) Rapporto sul mercato del lavoro 2011-2012, Roma.

Elias, P. (1997) Occupational classification (ISCO88): concepts, methods, reliability, validity and cross-national comparability, OECD labour market and social policy occasional papers $n$. 20, OECD Publishing.

Elias, P.; McKnight, A. (2001) Skill measurement in official statistics: recent developments in the UK and the rest of Europe, in Oxford Economic Papers n. 3/2001, pp. 508-540.

Elias, P. and K. Purcell (2004). SOC(HE): a classification of occupations for studying the graduate labour market. Research Paper 6, University of Warwick, Institute for Employment Research. 
Elias, P. and Purcell, K. (2013) Classifying graduate occupation for the knowledge society, HECSU working paper n. 5/2013.

Eurostat (2008) Enterprises by size class - overview of SMEs in the EU - Issue number 31/2008

Figueiredo, H.; Teixeira, P.; Rubery, J. (2011) Is Mass Higher Education Working? An Update and a Reflection on the Sustainability of Higher Education Expansion in Portugal, AlmaLaurea working papers n. 14, Bologna.

Gallo, F.; Scalisi, P.; Scarnera, A. (2007) L'indagine sulle professioni. Contenuti, metodologia e organizzazione, in Metodi e norme n. 42, ISTAT, Rome.

Gallo, F.; Scalisi, P. (2012) Rappresentare il lavoro che cambia. Una lettura diacronica dell'osservazione statistica delle professioni, in Sociologia del Lavoro n. 2/2012.

Goldthorpe, J. H. (1988) Making class and status operational: concept formation, application and evaluation, ESRC-SCPR seminar working paper.

HEFCE (2011) Approaches to measuring employment circumstances of recent graduates, Issues Paper n. 2, Bristol, Higher Education Funding Council for England.

ILO (1990) International Standard Classification for Occupations (ISCO88), Geneva.

ILO (2012) International Standard Classification for Occupations (ISCO08), Geneva.

ISTAT (1991) Classificazione delle Professioni, Metodi e norme, serie C, Rome.

ISTAT (2001) Classificazione delle Professioni, Metodi e norme, serie C, Rome.

ISTAT (2009) Indagine campionaria sulle professioni, Rome.

Kochan, T. A.; Barley, S. R; Mavor, A. S. (1999) The changing nature of work. Implications for occupational analysis, National Research Council, National Academy Press, Washington DC.

Moretti, E. (2013) The New Geography of Jobs, Mariner Books, New York.

Peterson, N. G.; Mumford, M. D.; Borman, W. C.; Jeanneret, P. R.; Fleishman, F. A. (1999) An occupational information system for the $21^{\text {st }}$ Century: the development of $\mathrm{O}^{*}$ Net, American Psychological Association, Washington DC. 
Purcell, K. and P. Elias (2014 forthcoming) Graduates and graduate jobs: what's happening in the UK labour market?, mimeo.

Purcell, K.; Elias, P.; Wilton, N. (2004) Higher Education Skills and Employment: careers and jobs in the graduate labour market, Research paper n. 3, University of Warwick, Institute for Employment Research, Coventry.

Rafferty A.; Dale, A. (2008) Ethnic Differences in graduate over-education in the UK, CSSR Working paper n. 5/2008, Cathie Marsh Centre for Census and Survey Research, University of Manchester, Manchester.

Reich, R. (1991) The Work of Nations, Vintage Books, New York.

Unni, J. and Sarkar, S. (2011) Employment and Education in India: the demand side story, Working Paper for ESRC Pathfinder project 'Assessing the impact of higher education expansion on economic restructuring, occupational change and access to opportunities in Brazil and India'.

UUK (2010) Recession to Recovery: Changes in student choices and graduate employment, Universities UK, London. 


\section{APPENDIX 1}

Table A.1 The 109 O*Net variables of the ISFOL-ISTAT survey regrouped in the SOC(HE)2010 clusters of competence

\begin{tabular}{|c|c|c|c|}
\hline $\begin{array}{l}\text { Variable name } \\
\text { in } \\
\text { ISFOL/ISTAT } \\
\quad \text { Survey }\end{array}$ & Label & Description & Cluster \\
\hline B1a & $\begin{array}{l}\text { Administration and } \\
\text { management of enterprise }\end{array}$ & $\begin{array}{l}\text { Knowledge of principles and methods governing the } \\
\text { company and its management regarding the strategic } \\
\text { planning, allocation of human, financial and material } \\
\text { control techniques, production methods and coordination } \\
\text { of people and resources }\end{array}$ & ORC \\
\hline B2a & Paperwork & $\begin{array}{l}\text { Knowledge of administrative procedures and office } \\
\text { programs, word processing, file management techniques } \\
\text { and databases or shorthand and transcription rules or } \\
\text { procedures and other languages approved by the office } \\
\text { work }\end{array}$ & EXP \\
\hline B3a & Economics and Accounting & $\begin{array}{l}\text { Knowledge of the principles and practices of economics } \\
\text { and accounting }\end{array}$ & EXP \\
\hline B4a & Marketing and sales & $\begin{array}{l}\text { Knowledge of principles and methods for presenting, } \\
\text { promoting and selling products or services. Includes the } \\
\text { development of strategies and tactics of marketing, } \\
\text { presentation, sales techniques and control }\end{array}$ & $\mathrm{COM}$ \\
\hline B5a & $\begin{array}{l}\text { Services to customers and } \\
\text { people }\end{array}$ & $\begin{array}{l}\text { Knowledge of principles and procedures for providing } \\
\text { services to customers and people. Includes an assessment } \\
\text { of customer needs, the achievement of quality standards } \\
\text { and evaluation of customer satisfaction }\end{array}$ & ORC \\
\hline B6a & $\begin{array}{l}\text { Personnel management and } \\
\text { human resources }\end{array}$ & $\begin{array}{l}\text { Knowledge of principles and procedures for the } \\
\text { recruitment, selection, training, staff remuneration to } \\
\text { labor relations and negotiations and the management of } \\
\text { information systems personnel }\end{array}$ & EXP \\
\hline B7a & Production and process & $\begin{array}{l}\text { Knowledge of raw materials, production processes, the } \\
\text { techniques for quality control }\end{array}$ & EXP \\
\hline B8a & Food production & $\begin{array}{l}\text { Knowledge of techniques and equipment necessary for } \\
\text { sowing, cultivating and harvesting food products (both } \\
\text { plant and animal) for consumption, including those } \\
\text { relating to the conservation / storage }\end{array}$ & EXP \\
\hline
\end{tabular}


Knowledge of circuit boards, processors, chips electronic

B9a Computer and electronics

B10a Engineering and Technology

B11a

B12a

B13a

B14a

B15a

B16a

B17a

B18a

B19a
Engineering Design

Building and construction

Mathematics

Physics

Chemistry

Biology

Psychology

Sociology and Anthropology
Mechanics equipment, hardware and computer software, including knowledge of application packages and programming

$$
\text { languages }
$$

Knowledge of the practical application of engineering science and technology. Includes applying principles, techniques, procedures and the use of tools for designing and producing different goods or services

Knowledge of design techniques, tools, and principles used in the execution of technical projects of precision, detailed plans, drawings and models

Knowledge of materials, methods and tools used in the construction and repair of houses, buildings, or other structures such as highways and roads

Knowledge of machines and tools, including their design, their use, their repair and maintenance Knowledge of arithmetic, algebra, geometry, calculus, statistics, and their applications

EXP Knowledge of the principles and laws of physics, their interrelationships and their applications to understanding fluid dynamics, materials and structures and processes of the atmosphere and mechanical, electrical, atomic and subatomic

Knowledge of the composition, structure and properties of substances, processes and chemical changes below, this includes the use of chemicals, knowledge of their interactions, danger signs, production techniques and chemicals of the methods of remediation

Knowledge of plant and animal organisms, their tissues, cells, their functions, interdependencies, and their interactions with the environment Knowledge of human behavior and performance, individual differences in attitudes, personality and interests, the mechanisms of learning and motivation, methods of psychological research and assessment and treatment of behavioral and affective disorders

Knowledge of the behavior and group dynamics, societal trends and influences, human migrations, ethnicity 
B20a

B21a

B22a

B23a

B24a

B26a

B29a

B30a
Geography

Medicine and dentistry

Therapy and counseling

Education and training

Italian language

Foreign language

Art

History and archeology

Philosophy and Theology

Civil protection and public safety

Legislation and institutions
Knowledge of principles and methods for describing and representing the land, sea and air masses, including their physical characteristics, locations, interrelationships, and distribution of plant, animal and human settlements Knowledge of information and techniques needed to diagnose and treat injuries, diseases and deformities of the human body, including knowledge of the symptoms, treatment alternatives, properties and interactions of drugs and preventive care

Knowledge of the principles, methods, and procedures for diagnosis, treatment and rehabilitation of physical and mental dysfunctions, and for the advice and guidance in careers

Knowledge of principles and methods for curriculum and training design, teaching and training, collectively and individually, to measure the effects of training

Knowledge of the structure and content of the Italian language or the meaning and pronunciation of words, rules of composition, and grammar

Knowledge of the structure and content of a foreign language or the meaning and pronunciation of words, rules of composition, and grammar

Knowledge of the theory and techniques required to compose, produce and create music, dance, visual arts, drama and sculpture

Knowledge of historical events and their causes, indicators, and effects on civilizations and cultures Knowledge of different philosophical systems and the different religions of the basic principles, values, ethics, ways of thinking, customs, practices, and their impact on culture

Knowledge of the most important equipment, policies, procedures, and strategies to promote effective security operations locally and nationally for the protection of people, information, property, and institutions

Knowledge of laws, legal procedures, regulations, enforcement of judgments, the role of political institutions and processes of democracy 


\begin{tabular}{|c|c|c|c|}
\hline B31a & Telecommunications & $\begin{array}{l}\text { Knowledge of transmission, broadcasting and how to } \\
\text { connect and control of telecommunications systems }\end{array}$ & EXP \\
\hline B32a & Communication and Media & $\begin{array}{l}\text { Knowledge of the production of media, techniques and } \\
\text { methods to spread information, alternative means to } \\
\text { inform and entertain in a written, oral and visual }\end{array}$ & EXP \\
\hline B33a & Transport & $\begin{array}{l}\text { Knowledge of principles and methods for transporting } \\
\text { people or goods by aircraft, rail, sea, or road, including } \\
\text { the knowledge to calculate the costs and benefits of } \\
\text { transport }\end{array}$ & EXP \\
\hline $\mathrm{C} 1 \mathrm{a}$ & Understand written texts & $\begin{array}{l}\text { Understanding written sentences and paragraphs in work } \\
\text { related documents }\end{array}$ & $\mathrm{COM}$ \\
\hline $\mathrm{C} 2 \mathrm{a}$ & Listen actively & $\begin{array}{l}\text { Making full attention to what other people are saying, } \\
\text { pausing to understand the main points by asking } \\
\text { questions at the appropriate time and avoiding } \\
\text { interruptions inappropriate }\end{array}$ & $\mathrm{COM}$ \\
\hline $\mathrm{C} 3 \mathrm{a}$ & Write & $\begin{array}{l}\text { Communicating effectively in writing as appropriate to } \\
\text { the needs of recipients. }\end{array}$ & $\mathrm{COM}$ \\
\hline $\mathrm{C} 4 \mathrm{a}$ & Talk & Talking to others to convey information effectively & $\mathrm{COM}$ \\
\hline $\mathrm{C} 5 \mathrm{a}$ & Mathematics & Use mathematics to solve problems. & EXP \\
\hline C6a & Sciences & Apply scientific rules and methods to solve problems. & EXP \\
\hline $\mathrm{C} 7 \mathrm{a}$ & Critical Thinking & $\begin{array}{l}\text { Using logic and reasoning to identify the strengths and } \\
\text { weaknesses of solutions, conclusions or alternative } \\
\text { approaches to problems. }\end{array}$ & ORC \\
\hline $\mathrm{C} 8 \mathrm{a}$ & Active Learning & $\begin{array}{l}\text { Understand the implications of new information for } \\
\text { problem solving present, future and for decision-making }\end{array}$ & ORC \\
\hline $\mathrm{C} 9 \mathrm{a}$ & Learning strategies & $\begin{array}{l}\text { Select and use appropriate methods and procedures } \\
\text { training to learn or teach to learn }\end{array}$ & EXP \\
\hline $\mathrm{C} 10 \mathrm{a}$ & Monitor & $\begin{array}{l}\text { Monitor and evaluate personal work performance, other } \\
\text { persons or organizations to improve or correct }\end{array}$ & EXP \\
\hline $\mathrm{C} 11 \mathrm{a}$ & Social perception & $\begin{array}{l}\text { Understand the reactions of others and react in certain } \\
\text { ways because }\end{array}$ & $\mathrm{COM}$ \\
\hline $\mathrm{C} 12 \mathrm{a}$ & Coordinate with other & Coordinate their actions with those of other & ORC \\
\hline $\mathrm{C} 13 \mathrm{a}$ & Persuade & Persuading others to change their attitudes or behavior & $\mathrm{COM}$ \\
\hline $\mathrm{C} 14 \mathrm{a}$ & Negotiate & $\begin{array}{l}\text { Discuss and negotiate with each other to reach an } \\
\text { agreement and try to reconcile different views }\end{array}$ & $\mathrm{COM}$ \\
\hline
\end{tabular}




\begin{tabular}{|c|c|c|c|}
\hline $\mathrm{C} 15 \mathrm{a}$ & Instruct & Teach others how to do certain things & $\mathrm{COM}$ \\
\hline C16a & Service orientation & Actively seek solutions to meet the needs of the other & $\mathrm{COM}$ \\
\hline $\mathrm{C} 17 \mathrm{a}$ & Solve complex problems & $\begin{array}{l}\text { Identifying complex problems and gather information to } \\
\text { evaluate possible options and solutions }\end{array}$ & ORC \\
\hline $\mathrm{C} 18 \mathrm{a}$ & $\begin{array}{l}\text { Analysis of the operational } \\
\text { phases }\end{array}$ & $\begin{array}{l}\text { Analyze the characteristics and requirements of tools, } \\
\text { services or products necessary for the implementation of } \\
\text { a project }\end{array}$ & ORC \\
\hline $\mathrm{C} 19 \mathrm{a}$ & Technological design & $\begin{array}{l}\text { Producing or adapting equipment and technology to meet } \\
\text { the needs of users }\end{array}$ & EXP \\
\hline $\mathrm{C} 20 \mathrm{a}$ & Select tools & Identify the tools necessary for the performance of a job. & NON-G \\
\hline $\mathrm{C} 21 \mathrm{a}$ & Install & $\begin{array}{l}\text { Install equipment, machines, wiring, or programs } \\
\text { applying the technical specifications }\end{array}$ & NON-G \\
\hline $\mathrm{C} 22 \mathrm{a}$ & Program & Write computer programs for various purposes & EXP \\
\hline $\mathrm{C} 23 \mathrm{a}$ & Quality Control & $\begin{array}{c}\text { Conduct tests and inspections of products, services, or } \\
\text { processes to evaluate quality or performance }\end{array}$ & EXP \\
\hline $\mathrm{C} 24 \mathrm{a}$ & Monitor machines & $\begin{array}{l}\text { Check liquid level measurement, dials, or other indicators } \\
\text { to ensure the correct operation of a machine }\end{array}$ & NON-G \\
\hline $\mathrm{C} 25 \mathrm{a}$ & Operate and monitor & $\begin{array}{l}\text { Check the operations and activities of equipment and } \\
\text { systems }\end{array}$ & NON-G \\
\hline $\mathrm{C} 26 \mathrm{a}$ & Maintenance & $\begin{array}{l}\text { Perform routine maintenance on equipment and } \\
\text { determine when and what kind of maintenance is needed }\end{array}$ & NON-G \\
\hline $\mathrm{C} 27 \mathrm{a}$ & Solve problems & $\begin{array}{l}\text { Determine causes of operating errors and deciding what } \\
\text { to do about them }\end{array}$ & NON-G \\
\hline $\mathrm{C} 28 \mathrm{a}$ & Repair & $\begin{array}{c}\text { Repairing machines or systems using the appropriate } \\
\text { equipment }\end{array}$ & NON-G \\
\hline $\mathrm{C} 29 \mathrm{a}$ & Analyze systems & $\begin{array}{l}\text { Determine how it should work a "system" (ie, machines, } \\
\text { factories, organizations, environments) and how } \\
\text { environmental changes, or operational situation will } \\
\text { affect his performance }\end{array}$ & EXP \\
\hline $\mathrm{C} 30 \mathrm{a}$ & Evaluate systems & $\begin{array}{l}\text { Identifying measures or indicators of system performance } \\
\text { (ie, machines, factories, organizations, environments) and } \\
\text { the actions needed to improve or correct in relation to the } \\
\text { objectives of the system }\end{array}$ & EXP \\
\hline C31a & Evaluate and decide & $\begin{array}{l}\text { Assess the costs and benefits of potential actions to } \\
\text { choose the most appropriate }\end{array}$ & ORC \\
\hline
\end{tabular}




\begin{tabular}{|c|c|c|c|}
\hline $\mathrm{C} 32 \mathrm{a}$ & Manage time & Manage your time and that of others & $\overline{\mathrm{ORC}}$ \\
\hline $\mathrm{C} 33 \mathrm{a}$ & Manage financial resources & $\begin{array}{l}\text { Determine how much money you need to spend to do a } \\
\text { job and account for expenses }\end{array}$ & ORC \\
\hline $\mathrm{C} 34 \mathrm{a}$ & Manage material resources & $\begin{array}{l}\text { Obtain and handle the appropriate use of equipment, } \\
\text { tools and materials needed to perform a job }\end{array}$ & ORC \\
\hline $\mathrm{C} 35 \mathrm{a}$ & Managing human resources & $\begin{array}{l}\text { Motivate, develop and direct the staff and to identify the } \\
\text { most appropriate staff to work }\end{array}$ & ORC \\
\hline G1a & Gather information & $\begin{array}{c}\text { Observe, receive or obtain in any way, information from } \\
\text { relevant sources }\end{array}$ & ORC \\
\hline $\mathrm{G} 2 \mathrm{a}$ & $\begin{array}{l}\text { Identify objects, actions and } \\
\text { events }\end{array}$ & $\begin{array}{l}\text { Identify information cataloging, evaluating and } \\
\text { recognizing the differences and similarities }\end{array}$ & EXP \\
\hline G3a & $\begin{array}{l}\text { Control processes, materials, } \\
\text { or surroundings }\end{array}$ & $\begin{array}{c}\text { Check and reviewing information from materials, events, } \\
\text { or the environment to detect or assess problems }\end{array}$ & EXP \\
\hline $\mathrm{G} 4 \mathrm{a}$ & $\begin{array}{l}\text { Inspect equipment, structures } \\
\text { or materials }\end{array}$ & $\begin{array}{l}\text { Inspect equipment, structures, or materials to identify the } \\
\text { causes of errors or other problems or defects }\end{array}$ & EXP \\
\hline G5a & $\begin{array}{l}\text { Estimate the quantifiable } \\
\text { characteristics of products, } \\
\text { events or information }\end{array}$ & $\begin{array}{c}\text { Estimating sizes, distances, and quantities, or } \\
\text { determining time, costs, resources, or materials needed to } \\
\text { perform a specific work. }\end{array}$ & EXP \\
\hline G6a & $\begin{array}{l}\text { Assess the quality of items, } \\
\text { services or persons }\end{array}$ & $\begin{array}{l}\text { Estimate the value, importance, or quality of things or } \\
\text { people }\end{array}$ & EXP \\
\hline G7a & $\begin{array}{l}\text { Evaluating information to } \\
\text { determine compliance with } \\
\text { the standard }\end{array}$ & $\begin{array}{l}\text { Use relevant information and individual opinions to } \\
\text { determine whether events or processes comply with } \\
\text { international standards, laws and regulations }\end{array}$ & EXP \\
\hline G8a & Process information & $\begin{array}{c}\text { Compile, code, categorize, calculate, tabulate, review or } \\
\text { verify information or data }\end{array}$ & EXP \\
\hline G9a & Analyzing data or information & $\begin{array}{l}\text { Identify the relationships, the reasons underlying facts or } \\
\text { information to disaggregate information or data into } \\
\text { separate parts }\end{array}$ & EXP \\
\hline G10a & $\begin{array}{l}\text { Make decisions and solve } \\
\text { problems }\end{array}$ & $\begin{array}{l}\text { Analyze information and evaluate results to choose the } \\
\text { best solution and solve problems }\end{array}$ & ORC \\
\hline G11a & Think creatively & $\begin{array}{l}\text { Developing, designing, or creating new applications, } \\
\text { ideas, relationships, and new systems and products } \\
\text { (including artistic contributions) }\end{array}$ & EXP \\
\hline G12a & $\begin{array}{l}\text { Update and use knowledge } \\
\text { relevant }\end{array}$ & $\begin{array}{l}\text { Stay informed about technical changes and apply new } \\
\text { knowledge }\end{array}$ & EXP \\
\hline G13a & Develop goals and strategies & $\begin{array}{l}\text { Establish long-term goals, and specify the strategies and } \\
\text { actions to achieve them }\end{array}$ & ORC \\
\hline
\end{tabular}




\begin{tabular}{|c|c|c|c|}
\hline G14a & Plan the work and activities & $\begin{array}{l}\text { Schedule events, plans and activities or the work of other } \\
\text { people }\end{array}$ & $\overline{\text { ORC }}$ \\
\hline G15a & $\begin{array}{l}\text { Organize, plan and prioritize } \\
\text { work }\end{array}$ & $\begin{array}{c}\text { Develop specific objectives and work program setting } \\
\text { priorities }\end{array}$ & ORC \\
\hline G16a & General physical activities & $\begin{array}{l}\text { Perform physical activities that require you to move the } \\
\text { entire body or a considerable use of the arms and legs, } \\
\text { such as climbing, climbing stairs, standing balance, } \\
\text { walking, bending and manipulating materials }\end{array}$ & NON-G \\
\hline G17a & Handle and move objects & $\begin{array}{l}\text { Use hands and arms to handle, install, position, and } \\
\text { moving materials, or to manipulate objects }\end{array}$ & NON-G \\
\hline G18a & $\begin{array}{l}\text { Managing machines and } \\
\text { processes }\end{array}$ & $\begin{array}{l}\text { Use both the control mechanisms that direct physical } \\
\text { activity to operate machines or processes (not including } \\
\text { computers and vehicles) }\end{array}$ & NON-G \\
\hline G19a & Working with computers & $\begin{array}{l}\text { Using computers and computer systems (hardware and } \\
\text { software) to program, write software, set functions, enter } \\
\text { data, or process information }\end{array}$ & EXP \\
\hline G20a & $\begin{array}{c}\text { Maneuver vehicles, } \\
\text { mechanical or equipment }\end{array}$ & $\begin{array}{l}\text { Operate, operate, drive or drive vehicles or mechanical } \\
\text { equipment such as forklift trucks, transport vehicles, } \\
\text { aircraft or boats }\end{array}$ & NON-G \\
\hline G21a & $\begin{array}{l}\text { Write drafts, notes and draw } \\
\text { technical specifications for } \\
\text { components or equipment }\end{array}$ & $\begin{array}{l}\text { Produce documentation, detailed instructions, drawings, } \\
\text { or specifications to explain how they are manufactured, } \\
\text { assembled, modified, maintained, or used devices, } \\
\text { components, equipment or facilities }\end{array}$ & $\mathrm{COM}$ \\
\hline G22a & $\begin{array}{l}\text { Repair and maintenance of } \\
\text { mechanical equipment }\end{array}$ & $\begin{array}{l}\text { Do maintenance, repair, adjust and test machines, } \\
\text { devices, moving parts and mechanical equipment (non- } \\
\text { electronic) }\end{array}$ & NON-G \\
\hline G23a & $\begin{array}{l}\text { Repair and maintenance of } \\
\text { electronic equipment }\end{array}$ & $\begin{array}{c}\text { Do maintenance, repair, adjust, calibrate, or try to } \\
\text { develop machines, computer peripherals and electronic } \\
\text { (not mechanical) }\end{array}$ & NON-G \\
\hline G24a & Document, record information & $\begin{array}{l}\text { Enter, transcribe, record, store, or maintain information } \\
\text { in written, electronic or magnetic }\end{array}$ & EXP \\
\hline G25a & $\begin{array}{l}\text { Interpret the meaning of } \\
\text { information }\end{array}$ & $\begin{array}{l}\text { Interpret or explain the meaning of information and their } \\
\text { possible use }\end{array}$ & $\mathrm{COM}$ \\
\hline G26a & $\begin{array}{l}\text { Communicate with superiors, } \\
\text { colleagues and subordinates }\end{array}$ & $\begin{array}{c}\text { Provide information to superiors, colleagues and } \\
\text { subordinates by telephone, in writing, by e-mail or in } \\
\text { person }\end{array}$ & $\mathrm{COM}$ \\
\hline G27a & $\begin{array}{l}\text { Communicating with people } \\
\text { outside the organization }\end{array}$ & $\begin{array}{l}\text { Communicating with people outside the organization, } \\
\text { representing the same to customers, the public, }\end{array}$ & $\mathrm{COM}$ \\
\hline
\end{tabular}


government, and other external entities, personally, in writing, by telephone or by e-mail.

G28a

G29a

G30a

G31a

G33a

G34a

G35a

G36a

G37a

G38a

G39a

G40a

G41a
Establishing and maintaining

interpersonal relationships

Assist and take care of other

Sell goods or affect other

Resolve disputes and negotiate with other people

Working in direct contact with the public or perform

Coordinate the work and activities of other

Grow and enable working groups

Train and teach

Guide, direct, and motivate subordinates

Train and develop others

Provision of advice and tips to other people

Perform administrative tasks

Recruit staff

Monitor and control resources
Create constructive and cooperative working relationships and maintain them over time.

Providing personal assistance, medical attention, emotional support, or other personal care to others

$\mathrm{COM}$ (colleagues, clients, patients)

Convince others to buy goods or goods or make them change their minds or behavior

Handle complaints, negotiate, soothe disputes and resolve conflicts

Perform for the public or deal directly with the public. Includes serving customers in public establishments or shops and receiving clients or guests

Far so that the components of a group work together to perform the tasks assigned

Encourage and nurture mutual trust, respect, and ORC cooperation among members of a group.

Identify the training needs of other people, to develop programs or formal education or training, and teaching or instructing others

Guide and direct subordinates defining the standards in performance and control of these

ORC

Identify growth needs of other people and train, take the lead or help others to improve their knowledge and skills

COM

Provide guidelines and suggestions qualified to management or other groups on technical matters or relating to systems or processes

Daily administrative tasks, such as managing files and attend practices

NON-G

Recruit, interview, select, hire and promote employees in an organization

Monitoring and controlling resources and overseeing the ORC spending activities 


\section{APPENDIX 2}

Table A.2 EQF Framework (source: http://ec.europa.eu/education/lifelong-learning-policy/eqf en.htm)

\begin{tabular}{|c|c|c|c|c|}
\hline 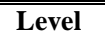 & Knowledge & Skills & Competence & Example \\
\hline Level 1 & $\begin{array}{l}\text { Basic general } \\
\text { knowledge }\end{array}$ & $\begin{array}{c}\text { basic skills required to carry } \\
\text { out simple tasks }\end{array}$ & $\begin{array}{l}\text { work or study under direct } \\
\text { supervision in a structured } \\
\text { context }\end{array}$ & \\
\hline Level 2 & $\begin{array}{c}\text { Basic factual } \\
\text { knowledge of a field } \\
\text { of work or study }\end{array}$ & $\begin{array}{l}\text { basic cognitive and practical } \\
\text { skills required to use } \\
\text { relevant information in } \\
\text { order to carry out tasks and } \\
\text { to solve routine problems } \\
\text { using simple rules and tools } \\
\text { a range of cognitive and }\end{array}$ & $\begin{array}{l}\text { work or study under } \\
\text { supervision with some } \\
\text { autonomy }\end{array}$ & lower secondary school \\
\hline Level 3 & $\begin{array}{l}\text { and general concepts, } \\
\text { in a field of work or } \\
\text { study }\end{array}$ & $\begin{array}{l}\text { problems by selecting and } \\
\text { applying basic methods, } \\
\text { tools, materials and } \\
\text { information }\end{array}$ & $\begin{array}{c}\text { or study; adapt own } \\
\text { behaviour to circumstances in } \\
\text { solving problems }\end{array}$ & \\
\hline Level 4 & $\begin{array}{l}\text { Factual and theoretical } \\
\text { knowledge in broad } \\
\text { contexts within a field } \\
\text { of work or study }\end{array}$ & $\begin{array}{l}\text { a range of cognitive and } \\
\text { practical skills required to } \\
\text { generate solutions to } \\
\text { specific problems in a field } \\
\text { of work or study }\end{array}$ & $\begin{array}{l}\text { exercise self-management } \\
\text { within the guidelines of work } \\
\text { or study contexts that are } \\
\text { usually predictable, but are } \\
\text { subject to change; supervise } \\
\text { the routine work of others, } \\
\text { taking some responsibility for } \\
\text { the evaluation and } \\
\text { improvement of work or } \\
\text { study activities }\end{array}$ & Lower middle school \\
\hline Level 5 & $\begin{array}{c}\text { Comprehensive, } \\
\text { specialised, factual } \\
\text { and theoretical } \\
\text { knowledge within a } \\
\text { field of work or study } \\
\text { and an awareness of } \\
\text { the boundaries of that } \\
\text { knowledge }\end{array}$ & $\begin{array}{c}\text { a comprehensive range of } \\
\text { cognitive and practical } \\
\text { skills required to develop } \\
\text { creative solutions to abstract } \\
\text { problems }\end{array}$ & $\begin{array}{c}\text { exercise management and } \\
\text { supervision in contexts of } \\
\text { work or study activities where } \\
\text { there is unpredictable change; } \\
\text { review and develop } \\
\text { performance of self and } \\
\text { others }\end{array}$ & Higher middle school \\
\hline $\begin{array}{c}\text { Level } 6 \\
\text { (HE) }\end{array}$ & $\begin{array}{l}\text { Advanced knowledge } \\
\text { of a field of work or } \\
\text { study, involving a } \\
\text { critical understanding } \\
\text { of theories and } \\
\text { principles }\end{array}$ & $\begin{array}{c}\text { advanced skills, } \\
\text { demonstrating mastery and } \\
\text { innovation, required to } \\
\text { solve complex and } \\
\text { unpredictable problems in a } \\
\text { specialised field of work or } \\
\text { study }\end{array}$ & $\begin{array}{l}\text { manage complex technical or } \\
\text { professional activities or } \\
\text { projects, taking responsibility } \\
\text { for decision-making in } \\
\text { unpredictable work or study } \\
\text { contexts; take responsibility } \\
\text { for managing professional } \\
\text { development of individuals } \\
\text { and groups }\end{array}$ & $\begin{array}{c}\text { Honours bachelor } \\
\text { degree, vocational } \\
\text { university German State- } \\
\text { certified Engineer, Business } \\
\text { Manager and Designer } \\
\text { (Fachhcochschule) } \\
\text { Bachelor, City and Guilds, } \\
\text { Graduateship(GCGI) }\end{array}$ \\
\hline
\end{tabular}




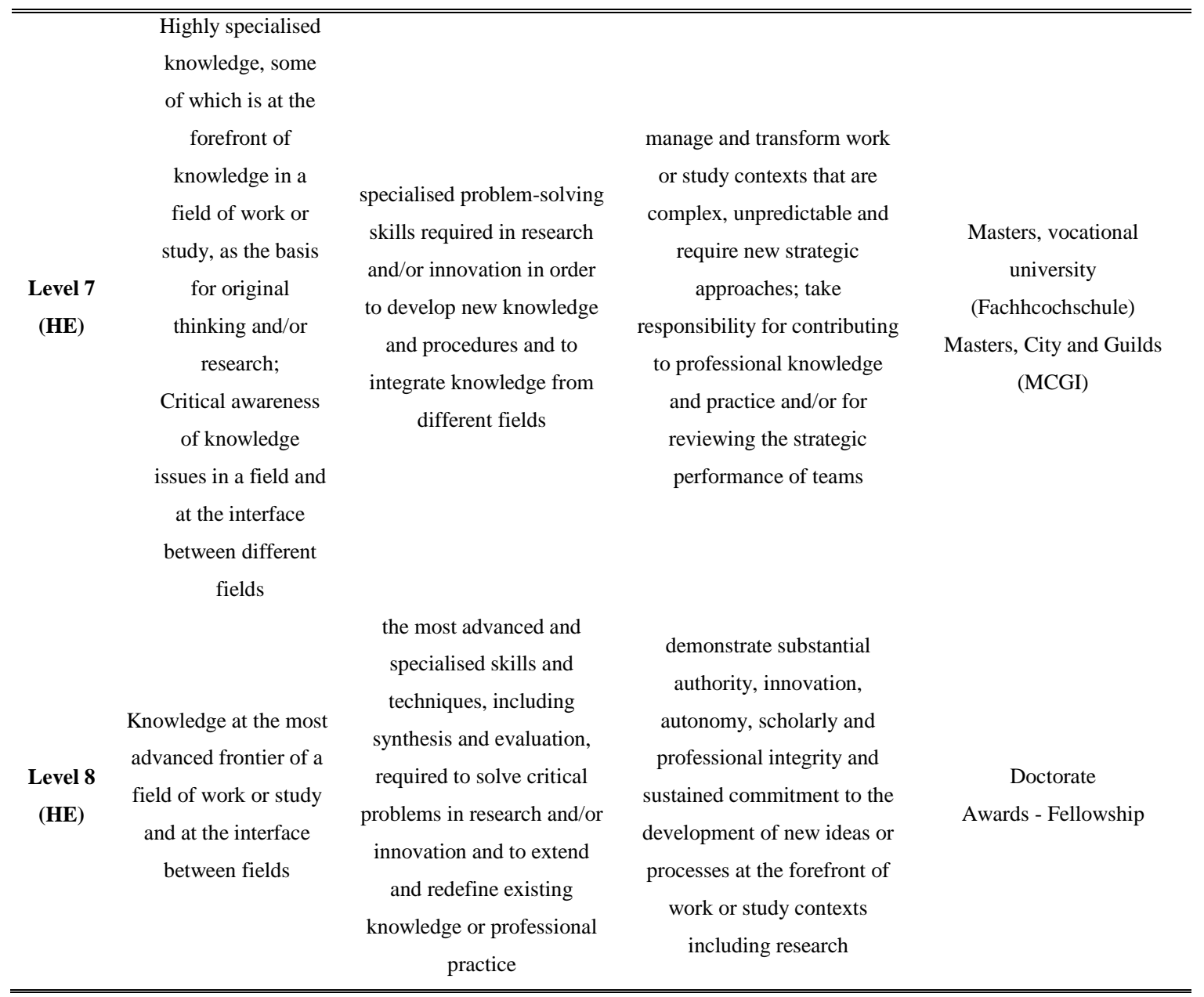




\section{APPENDIX 3}

Table A.3 EQF Levels and SOC(HE)-Italy groups per job title

\begin{tabular}{|c|c|c|c|c|c|c|}
\hline Code & Job Title & $\begin{array}{c}\mathbf{E X P} \\
\text { cluster }\end{array}$ & $\begin{array}{c}\text { STR } \\
\text { Cluste } \\
\text { r }\end{array}$ & $\begin{array}{l}\text { COM } \\
\text { Clister }\end{array}$ & $\begin{array}{c}\text { EQF } \\
\text { Leve } \\
1\end{array}$ & $\begin{array}{l}\text { SOC(HE)- } \\
\text { Italy Group }\end{array}$ \\
\hline 1.1.1.1.0 & $\begin{array}{l}\text { Elected officers, representatives and ministers in National } \\
\qquad \text { Assemblies }\end{array}$ & 6,96 & 6,63 & 6,47 & 7 & EXP \\
\hline 1.1.1.2.0 & $\begin{array}{l}\text { Elected officers, representatives and deputies in Regional } \\
\text { Assemblies }\end{array}$ & 6,36 & 6,02 & 6,47 & 6 & $\mathrm{COM}$ \\
\hline 1.1.1.3.0 & Elected officers, representatives and deputies in Provinces & 6,04 & 5,92 & 6,28 & 6 & $\mathrm{COM}$ \\
\hline 1.1.1.4.0 & Elected officers, representatives and assessors in City Councils & 5,8 & 5,87 & 5,95 & 6 & $\mathrm{COM}$ \\
\hline 1.1.2.1.0 & Ambassadors, plenipotentiary and other diplomats & - & 6,88 & 7,11 & 7 & $\mathrm{COM}$ \\
\hline 1.1 .2 .2 .1 & Chief executives and senior officials & 6,7 & 6,51 & 6,67 & 7 & EXP \\
\hline 1.1 .2 .2 .2 & Head of police and police commissioners & 6,85 & 6,67 & 6,61 & 7 & EXP \\
\hline 1.1 .2 .2 .3 & General Secretaries and other public officers & 6,28 & 6,35 & 6,4 & 6 & $\mathrm{COM}$ \\
\hline 1.1 .2 .3 .1 & Public education territorial managers & 6,14 & 6,12 & 6,14 & 6 & $\mathrm{COM}$ \\
\hline 1.1 .2 .3 .2 & Cultural heritage officers & 6,08 & 6,26 & 6,24 & 6 & STR \\
\hline 1.1.2.4.1 & Local government, public utilities, departmental chief executives & 6,72 & 6,92 & 6,92 & 7 & STR \\
\hline 1.1.2.4.2 & Research centers, universities and schools directors & 6,43 & 6,32 & 6,54 & 6 & $\mathrm{COM}$ \\
\hline 1.1 .2 .4 .3 & Health chief executives and directors & 6,6 & 6,65 & 6,48 & 7 & STR \\
\hline 1.1 .2 .5 .1 & Local government, public utilities, departmental executives & 6,04 & 6,1 & 6,19 & 6 & $\mathrm{COM}$ \\
\hline 1.1.2.5.2 & Research centers, universities and schools executives & 7,09 & 7,1 & 7,03 & 7 & STR \\
\hline 1.1.2.5.3 & Health executives & 6,48 & 6,44 & 6,44 & 6 & EXP \\
\hline 1.1.3.1.0 & Senior presidents of tribunals and judiciary seniors & 6,34 & 6,2 & 6,59 & 6 & $\mathrm{COM}$ \\
\hline 1.1.3.2.0 & $\begin{array}{l}\text { Senior presidents of administrative and special tribunals and } \\
\text { senior officers of administrative and special judiciary }\end{array}$ & 6,67 & 6,26 & 6,55 & 6 & EXP \\
\hline 1.1.4.1.1 & Political parties executives & 5,52 & 5,68 & 5,96 & 6 & $\mathrm{COM}$ \\
\hline 1.1.4.1.2 & Trade unions executives & 6,16 & 6,27 & 6,54 & 6 & $\mathrm{COM}$ \\
\hline 1.1.4.2.0 & Humanitarian, scientific and cultural associations managers & 5,92 & 5,95 & 6,18 & 6 & $\mathrm{COM}$ \\
\hline 1.2.1.1.0 & $\begin{array}{l}\text { Proprietors and directors in agriculture, forestry, hunting and } \\
\text { fishery }\end{array}$ & 5,14 & 5,05 & 4,91 & 5 & NON-G \\
\hline 1.2.1.2.0 & Proprietors, directors in manufacturing & 6 & 6,19 & 6,02 & 6 & STR \\
\hline 1.2.1.3.0 & Proprietors, directors in construction & 5,76 & 5,7 & 5,57 & 6 & EXP \\
\hline 1.2.1.4.0 & Proprietors and directors in retail and wholesale & 5,88 & 5,6 & 5,56 & 6 & EXP \\
\hline 1.2 .1 .5 .0 & Proprietors and directors in hospitality and leisure & 5,36 & 5,8 & 5,49 & 6 & STR \\
\hline 1.2 .1 .6 .0 & Proprietors and directors in transports and communications & 5,68 & 5,72 & 5,57 & 6 & STR \\
\hline 1.2.1.7.0 & Proprietors and directors in firm services and financial services & 5,92 & 6,14 & 5,94 & 6 & STR \\
\hline 1.2 .1 .8 .0 & Proprietors and directors in cleaning and in-person services & 5,68 & 5,57 & 5,55 & 6 & EXP \\
\hline 1.2.1.9.0 & Proprietors and directors in other services & 6,48 & 6,22 & 6,34 & 6 & EXP \\
\hline 1.2.2.1.0 & Managers in agricolture, forestry, hunting and fishery & 5,6 & 5,69 & 5,6 & 6 & STR \\
\hline 1.2 .2 .2 .0 & Managers in manufacturing & 6,4 & 6,21 & 6,03 & 6 & EXP \\
\hline 1.2 .2 .3 .0 & Managers in constructions & 6,48 & 6,26 & 6,21 & 6 & EXP \\
\hline 1.2 .2 .4 .0 & Managers in retail and wholesale & 5,68 & 5,51 & 5,48 & 6 & EXP \\
\hline
\end{tabular}




\begin{tabular}{|c|c|c|c|c|c|c|}
\hline 1.2 .2 .5 .0 & Managers in hospitality and leisure & 5,92 & 6,08 & 5,92 & 6 & STR \\
\hline 1.2.2.6.0 & Managers in transports and communications & 6,16 & 5,73 & 5,54 & 6 & EXP \\
\hline 1.2 .2 .7 .0 & Managers in firm services and financial services & 6,32 & 6,48 & 6,61 & 6 & $\mathrm{COM}$ \\
\hline 1.2 .2 .8 .0 & Managers in cleaning and in-person services & 6 & 5,94 & 5,84 & 6 & EXP \\
\hline 1.2 .2 .9 .0 & Managers in other services & 6 & 6,18 & 6,27 & 6 & $\mathrm{COM}$ \\
\hline 1.2.3.1.0 & Directors of financial and administrative departments & 6,45 & 6,48 & 6,4 & 6 & STR \\
\hline 1.2.3.2.0 & $\begin{array}{l}\text { Directors in organization, human resources and industrial } \\
\text { relations }\end{array}$ & 6,56 & 6,42 & 6,32 & 6 & EXP \\
\hline 1.2 .3 .3 .0 & Marketing and sales directors & 6,4 & 6,49 & 6,57 & 6 & $\mathrm{COM}$ \\
\hline 1.2 .3 .4 .0 & Advetising and public relations directors & 6,04 & 6 & 6,33 & 6 & $\mathrm{COM}$ \\
\hline 1.2 .3 .5 .0 & Purchaising managers and directors & 5,52 & 5,72 & 5,89 & 6 & $\mathrm{COM}$ \\
\hline 1.2 .3 .6 .0 & Information technology and telecommunication directors & 6,03 & 5,98 & 5,9 & 6 & EXP \\
\hline 1.2.3.7.0 & RandD directors & 6,29 & 6,33 & 6,35 & 6 & COM \\
\hline 1.3.1.1.0 & $\begin{array}{l}\text { Proprietors, directors and managers in small businesses in } \\
\text { agricolture, forestry, hunting and fishery }\end{array}$ & 4,93 & 4,78 & 4,72 & 5 & NON-G \\
\hline 1.3.1.2.0 & $\begin{array}{l}\text { Proprietors, directors and managers in small businesses in } \\
\text { manufacturing }\end{array}$ & 5,68 & 5,85 & 5,68 & 6 & STR \\
\hline 1.3.1.3.0 & $\begin{array}{l}\text { Proprietors, directors and managers in small businesses in } \\
\text { constructions }\end{array}$ & 5,36 & 5,48 & 5,2 & 5 & NON-G \\
\hline 1.3.1.4.0 & $\begin{array}{l}\text { Proprietors, directors and managers in small businesses in retail } \\
\text { and wholesale }\end{array}$ & - & 5,25 & 5,24 & 5 & NON-G \\
\hline 1.3.1.5.0 & $\begin{array}{l}\text { Proprietors, directors and managers in small businesses in } \\
\text { hospitality and leisure }\end{array}$ & 5,12 & 5,3 & 5,32 & 5 & NON-G \\
\hline 1.3.1.6.0 & $\begin{array}{l}\text { Proprietors, directors and managers in small businesses in } \\
\text { transports and communications }\end{array}$ & 5,44 & 5,54 & 5,55 & 6 & $\mathrm{COM}$ \\
\hline 1.3.1.7.0 & $\begin{array}{c}\text { Proprietors, directors and managers in small businesses in firm } \\
\text { services and financial services }\end{array}$ & 5,8 & 5,96 & 5,81 & 6 & STR \\
\hline 1.3.1.8.0 & $\begin{array}{l}\text { Proprietors, directors and managers in small businesses in } \\
\text { cleaning and in-person services }\end{array}$ & 5,16 & 4,98 & 4,96 & 5 & NON-G \\
\hline 1.3.1.9.0 & $\begin{array}{l}\text { Proprietors, directors and managers in small businesses in other } \\
\text { services }\end{array}$ & 6,08 & 5,84 & 5,76 & 6 & EXP \\
\hline 2.1 .1 .1 .1 & Physical scientists & 7,3 & 6,92 & 7 & 7 & EXP \\
\hline 2.1.1.1.2 & Astronomers and astrophysicists & 7,26 & 7,08 & 7,12 & 7 & EXP \\
\hline 2.1 .1 .2 .1 & Chemical scientists and researchers & 6,26 & 5,88 & 6,1 & 6 & EXP \\
\hline 2.1 .1 .2 .2 & Chemical scientists (professors) & 6,08 & 5,56 & 5,95 & 6 & EXP \\
\hline 2.1 .1 .3 .1 & Mathematicians & 7,16 & 7,1 & 6,96 & 7 & EXP \\
\hline 2.1.1.3.2 & Statisticians & 6,34 & 6 & 6,21 & 6 & EXP \\
\hline 2.1 .1 .4 .1 & IT researchers & 6,84 & 7,2 & 7,09 & 7 & STR \\
\hline 2.1.1.4.2 & Software analysts, architects and designers & 6,23 & 5,96 & 5,6 & 6 & EXP \\
\hline 2.1 .1 .4 .3 & System analysists & 6,59 & 6,24 & 6 & 6 & EXP \\
\hline 2.1 .1 .4 .4 & IT security specialists & 6,14 & 5,89 & 5,82 & 6 & EXP \\
\hline 2.1 .1 .4 .5 & Network and telecommunications specialists & 6,08 & 5,65 & 5,88 & 6 & EXP \\
\hline 2.1 .1 .5 .1 & Geologists & 5,68 & 5,24 & 5,54 & 5 & EXP \\
\hline 2.1 .1 .5 .2 & Paleontologists & 6,41 & 6,22 & 6,49 & 6 & $\mathrm{COM}$ \\
\hline 2.1.1.5.3 & Geophysicists & 7,05 & - & 7,28 & 7 & $\mathrm{COM}$ \\
\hline
\end{tabular}




\begin{tabular}{|c|c|c|c|c|c|c|}
\hline 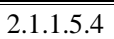 & Meteorologists & 6,64 & 6,24 & 6,14 & 6 & EXP \\
\hline 2.1.1.5.5 & Hydrologists & 6,52 & 6,48 & 6,32 & 6 & EXP \\
\hline 2.2 .1 .1 .1 & Mechanical engineers & 6,73 & 6,16 & 6,4 & 6 & EXP \\
\hline 2.2 .1 .1 .2 & Naval engineers & 7,12 & 6,64 & 6,72 & 7 & EXP \\
\hline 2.2 .1 .1 .3 & Aeronautical and aerospace engineers & 6,16 & 6,12 & 6,16 & 6 & EXP \\
\hline 2.2.1.1.4 & Nuclear engineers & 7,72 & - & 7,68 & 7 & EXP \\
\hline 2.2.1.2.1 & Metallurgical engineers & 6,64 & 6,16 & & 6 & EXP \\
\hline 2.2 .1 .2 .2 & Mining engineers & 6,76 & 6,54 & 6,98 & 7 & $\mathrm{COM}$ \\
\hline 2.2 .1 .3 .0 & Electrical and industrial automotion engineers & 6,3 & 6,27 & 6,2 & 6 & EXP \\
\hline 2.2 .1 .4 .1 & Elettronical engineers & 6,32 & 6,28 & 6,04 & 6 & EXP \\
\hline 2.2 .1 .4 .2 & Computer engineers & 6,9 & 6,8 & 6,8 & 7 & EXP \\
\hline 2.2 .1 .4 .3 & Engineers in telecommunication & 6,47 & - & 6,4 & 6 & EXP \\
\hline 2.2.1.5.1 & Chemical engineers & 6,55 & 6,45 & 6,4 & 6 & EXP \\
\hline 2.2.1.5.2 & Oil engineers & 6,78 & 6,74 & 6,72 & 7 & EXP \\
\hline 2.2 .1 .6 .1 & Construction engineers & 6,34 & 5,86 & 5,84 & 6 & EXP \\
\hline 2.2 .1 .6 .2 & Hydraulic engineers & 6,1 & 5,84 & 5,6 & 6 & EXP \\
\hline 2.2 .1 .9 .1 & Cartographers & 6,14 & 5,56 & 5,5 & 6 & EXP \\
\hline 2.2 .1 .9 .2 & Industrial engineers & 6,2 & 6,4 & 6,16 & 6 & STR \\
\hline 2.2.1.9.3 & Metal engineers & 6,66 & 6,58 & 6,56 & 7 & EXP \\
\hline 2.2 .1 .9 .4 & Biomedical engineers & 6,28 & 6,04 & 6,24 & 6 & EXP \\
\hline 2.2 .2 .0 .1 & Architects & 6,56 & 6,13 & 6,19 & 6 & EXP \\
\hline 2.2 .2 .0 .2 & City planners & 6,02 & 5,56 & 5,78 & 6 & EXP \\
\hline 2.3 .1 .1 .1 & Biologists & 6,22 & 6,12 & 5,98 & 6 & EXP \\
\hline 2.3 .1 .1 .2 & Biochemists & 6,04 & 5,63 & 5,81 & 6 & EXP \\
\hline 2.3 .1 .1 .3 & Biophysical scientists & 7 & 6,96 & 7,06 & 7 & $\mathrm{COM}$ \\
\hline 2.3 .1 .1 .4 & Food technologists & 6,64 & 6,24 & 6,56 & 6 & EXP \\
\hline 2.3 .1 .1 .5 & Botanical scientists & 6,29 & 6,32 & 6,3 & 6 & STR \\
\hline 2.3 .1 .1 .6 & Zoologists & 6,7 & 6,45 & 6,58 & 7 & EXP \\
\hline 2.3 .1 .1 .7 & Ecologists & 6,62 & 6,14 & 6,43 & 6 & EXP \\
\hline 2.3 .1 .2 .1 & Pharmacologists & 7,02 & 6,92 & 6,8 & 7 & EXP \\
\hline 2.3 .1 .2 .2 & Microbiologists & 6,32 & 5,67 & 5,94 & 6 & EXP \\
\hline 2.3 .1 .3 .0 & Agronomists & 5,26 & 5,16 & 5,44 & 5 & COM \\
\hline 2.3 .1 .4 .0 & Veterinarians & 5,58 & 5,43 & 5,54 & 6 & EXP \\
\hline 2.3 .1 .5 .0 & Pharmacists & 5,87 & 5,6 & 5,64 & 6 & EXP \\
\hline 2.4 .1 .1 .0 & Medical doctors & 6,75 & 6,26 & 6,58 & 7 & EXP \\
\hline 2.4.1.2.0 & Therapists & 6,51 & 5,89 & 6,45 & 6 & EXP \\
\hline 2.4 .1 .3 .0 & Surgeons & 7,24 & 6,44 & 6,63 & 7 & EXP \\
\hline 2.4 .1 .4 .0 & Clinical pathologists & 6,69 & 5,92 & 6,56 & 6 & EXP \\
\hline 2.4 .1 .5 .0 & Dentists & 6,21 & 5,66 & 5,97 & 6 & EXP \\
\hline 2.4 .1 .6 .0 & Medical radiographers & 6,92 & 5,76 & 6,22 & 6 & EXP \\
\hline 2.4 .1 .7 .1 & Dieticians and dental hygiene therapists & 6,3 & 6,03 & 6,19 & 6 & EXP \\
\hline 2.4.1.7.2 & Labour medicine doctors & 6,21 & 6,08 & 6,12 & 6 & EXP \\
\hline 2.4.1.7.3 & Epidemiologists & 6,5 & 6,21 & 6,29 & 6 & EXP \\
\hline
\end{tabular}




\begin{tabular}{|c|c|c|c|c|c|c|}
\hline 2.4 .1 .8 .0 & Anaesthetists and intensivists & 7,01 & 6,48 & 6,88 & 7 & EXP \\
\hline 2.5.1.1.1 & Public management specialists & 6,04 & 6,03 & 6,21 & 6 & $\mathrm{COM}$ \\
\hline 2.5 .1 .1 .2 & PA control specialists & 5,84 & 5,84 & 5,99 & 6 & $\mathrm{COM}$ \\
\hline 2.5.1.1.3 & Safety specialists & 6,08 & 6,18 & 6,03 & 6 & STR \\
\hline 2.5 .1 .2 .0 & Control and management specialists (private firms) & 6,4 & 6,38 & 6,36 & 6 & EXP \\
\hline 2.5 .1 .3 .1 & Human resources specialists & 6,44 & 6,48 & 6,05 & 6 & STR \\
\hline 2.5 .1 .3 .2 & Industrial relations specialists & 6,64 & 6,1 & 6,18 & 6 & EXP \\
\hline 2.5 .1 .4 .1 & Specialists in accounting & 5,96 & 5,68 & 5,78 & 6 & EXP \\
\hline 2.5 .1 .4 .2 & Tax professionals and experts & 5,95 & 5,57 & 6,03 & 6 & $\mathrm{COM}$ \\
\hline $2.5 \cdot 1.4 .3$ & Financial specialists & 6,06 & 6,03 & 6,13 & 6 & $\mathrm{COM}$ \\
\hline $2.5 \cdot 1.5 .1$ & Goods and services purchase specialists & 5,84 & 6,27 & 5,95 & 6 & STR \\
\hline 2.5 .1 .5 .2 & Marketing specialists & 6,24 & 6,07 & 6,25 & 6 & $\mathrm{COM}$ \\
\hline 2.5.1.5.3 & Market analysts & 6,64 & 6,4 & 6,4 & 6 & EXP \\
\hline 2.5 .1 .6 .0 & Public relations and advertising specialists & 6,32 & 5,95 & 6,49 & 6 & COM \\
\hline 2.5 .2 .1 .0 & Lawyers & 7,2 & 6,22 & 6,73 & 7 & EXP \\
\hline 2.5 .2 .2 .1 & Legal consultants (in private companies) & 6,72 & 6,62 & 6,55 & 7 & EXP \\
\hline 2.5 .2 .2 .2 & Legal consultants (in public companies) & 6,85 & 6,21 & 6,26 & 6 & EXP \\
\hline 2.5 .2 .3 .0 & Notarys & 6,91 & 6,18 & 6,86 & 7 & EXP \\
\hline 2.5.2.4.0 & Magistrates and judges & 6,69 & 5,88 & 6,86 & 6 & $\mathrm{COM}$ \\
\hline 2.5.3.1.1 & Political economists & 6,77 & 6,72 & 6,84 & 7 & $\mathrm{COM}$ \\
\hline 2.5 .3 .1 .2 & Business economists & 6,88 & 6,56 & 6,56 & 7 & EXP \\
\hline 2.5 .3 .2 .1 & Sociologists & 6,35 & 6,19 & 6,51 & 6 & $\mathrm{COM}$ \\
\hline 2.5 .3 .2 .2 & Anthropologists & 6,96 & 6,72 & 6,76 & 7 & EXP \\
\hline 2.5 .3 .2 .3 & Geographers & 6,72 & 6,51 & 6,54 & 7 & EXP \\
\hline 2.5.3.2.4 & Archaeologists & 6,64 & 6,06 & 6,16 & 6 & EXP \\
\hline 2.5 .3 .3 .1 & Psychologists & 7,1 & 6,88 & 6,93 & 7 & EXP \\
\hline 2.5 .3 .3 .2 & Psychotherapists & 7,12 & 6,8 & 6,92 & 7 & EXP \\
\hline 2.5 .3 .3 .3 & Labour psychologists & 7,17 & 7,33 & 6,7 & 7 & STR \\
\hline 2.5 .3 .4 .1 & Labour psychotherapists & 6,32 & 5,92 & 6,17 & 6 & EXP \\
\hline 2.5.3.4.2 & Art experts & 6,04 & 6,21 & 6,5 & 6 & $\mathrm{COM}$ \\
\hline 2.5.3.4.3 & Specialists in political science & 6,88 & 7,07 & 7,04 & 7 & STR \\
\hline 2.5 .3 .4 .4 & Philosophers & 6,7 & 6,4 & 6,59 & 7 & EXP \\
\hline 2.5 .4 .1 .1 & Writers and poets & 5,42 & 5,12 & 5,8 & 5 & $\mathrm{COM}$ \\
\hline 2.5 .4 .1 .2 & Dialogue and script editors and lyricists & 5,94 & 4,88 & 5,71 & 6 & EXP \\
\hline 2.5 .4 .1 .3 & Advertising editors & 6,22 & 5,88 & 6,17 & 6 & EXP \\
\hline 2.5.4.1.4 & Technical texts editors & 4,71 & 4,67 & 5,16 & 5 & NON-G \\
\hline 2.5 .4 .2 .0 & Journalists & 6,21 & 5,75 & 6,16 & 6 & EXP \\
\hline 2.5.4.3.0 & Interpreters and high level translators & 6,69 & 5,47 & 5,82 & 6 & EXP \\
\hline 2.5 .4 .4 .1 & Linguists and philologists & 6,94 & 6,13 & 6,51 & 7 & EXP \\
\hline 2.5 .4 .4 .2 & Text reviewers & 6,22 & 5,36 & 6,19 & 6 & EXP \\
\hline 2.5 .4 .5 .1 & Archivists & 6,2 & 5,64 & 6,03 & 6 & EXP \\
\hline 2.5 .4 .5 .2 & Librarians & 5,52 & 5,44 & 5,72 & 6 & $\mathrm{COM}$ \\
\hline 2.5.4.5.3 & Curators and museum curators & 5,6 & 5,56 & 5,87 & 6 & $\mathrm{COM}$ \\
\hline
\end{tabular}




\begin{tabular}{|c|c|c|c|c|c|c|}
\hline 2.5.5.1.1 & Painters, sculptors and designers & 5,77 & 5,46 & 5,1 & 5 & EXP \\
\hline 2.5 .5 .1 .2 & Cartoonists & 5,58 & 4,9 & 4,91 & 5 & EXP \\
\hline 2.5.5.1.3 & Art works restorers & 5,6 & 5,6 & 6,08 & 6 & $\mathrm{COM}$ \\
\hline 2.5 .5 .2 .1 & Film directors & 6,7 & 6,12 & 6,37 & 6 & EXP \\
\hline 2.5.5.2.2 & Actors & 5,6 & 5,46 & 6,08 & 6 & $\mathrm{COM}$ \\
\hline 2.5 .5 .2 .3 & Artistic directors & 5,3 & 5,35 & 5,49 & 5 & NON-G \\
\hline 2.5.5.2.4 & Scriptwriters and dramatists & 5,75 & 4,97 & 5,86 & 6 & $\mathrm{COM}$ \\
\hline 2.5 .5 .2 .5 & Set designers and scenographers & 6,12 & 5,25 & 5,35 & 6 & EXP \\
\hline 2.5 .5 .3 .1 & Choreographers & 6,26 & 5,93 & 5,98 & 6 & EXP \\
\hline 2.5 .5 .3 .2 & Dancers & 5,46 & 4,84 & 5,11 & 5 & NON-G \\
\hline 2.5.5.4.1 & Composeres & 5,69 & 5,18 & 5,9 & 6 & $\mathrm{COM}$ \\
\hline 2.5 .5 .4 .2 & Musical directors & 5,98 & 6,18 & 6,16 & 6 & STR \\
\hline 2.5.5.4.3 & Instrumentalists & 6,48 & 5,36 & 5,76 & 6 & EXP \\
\hline 2.5.5.5.0 & Singers & 4,65 & 4,57 & 5,49 & 5 & NON-G \\
\hline 2.5 .6 .0 .0 & Theologians and specialists in religious disciplines & 5,79 & 5,57 & 5,62 & 6 & EXP \\
\hline 2.6.1.1.0 & $\begin{array}{l}\text { Statistical sciences, maths, physics, chemical sciences university } \\
\text { professors }\end{array}$ & 6,93 & 6,96 & 7,07 & 7 & $\mathrm{COM}$ \\
\hline 2.6 .1 .2 .1 & Natural sciences university lecturers & 6,73 & 6,51 & 7 & 7 & $\mathrm{COM}$ \\
\hline 2.6.1.2.2 & Health sciences university lecturers & 6,86 & 6,6 & 6,95 & 7 & $\mathrm{COM}$ \\
\hline 2.6 .1 .3 .1 & Engineering university lecturers & 7,18 & 6,96 & 7,21 & 7 & $\mathrm{COM}$ \\
\hline 2.6 .1 .3 .2 & IT university lecturers & 7,2 & 7,24 & 7,32 & 7 & $\mathrm{COM}$ \\
\hline 2.6 .1 .4 .0 & Art, philology and antiquity university lecturers & 6,83 & 6,64 & 6,98 & 7 & $\mathrm{COM}$ \\
\hline 2.6.1.5.0 & $\begin{array}{l}\text { Hystory, philosophy, pedagogy and pyschology university } \\
\text { lecturers }\end{array}$ & 6,83 & 6,84 & 7 & 7 & $\mathrm{COM}$ \\
\hline 2.6 .1 .6 .0 & Law and social sciences university lecturers & 6,8 & 7,16 & 7,25 & 7 & $\mathrm{COM}$ \\
\hline 2.6.2.0.0 & $\begin{array}{l}\text { Mathematics and information sciences researchers and lab } \\
\text { assistants }\end{array}$ & 6,82 & 6,76 & 6,82 & 7 & EXP \\
\hline 2.6 .2 .0 .1 & Physical sciences researchers and lab assistants & 6,51 & 6,48 & 6,56 & 7 & $\mathrm{COM}$ \\
\hline 2.6.2.0.2 & $\begin{array}{l}\text { Chemical and pharmaceutical sciences researchers and lab } \\
\text { assistants }\end{array}$ & 6,2 & 6,29 & 6,17 & 6 & STR \\
\hline 2.6 .2 .0 .3 & Natural sciences researchers and lab assistants & 6,67 & 6,52 & 6,67 & 7 & EXP \\
\hline 2.6 .2 .0 .4 & Biological researchers and lab assistants & 6,8 & 6,8 & 6,7 & 7 & EXP \\
\hline 2.6 .2 .0 .5 & Medical and veterinary sciences researchers and lab assistants & 7,07 & 6,93 & 7,06 & 7 & EXP \\
\hline 2.6.2.0.6 & $\begin{array}{l}\text { Agricultural sciences and animal production researchers and lab } \\
\qquad \text { assistants }\end{array}$ & 6,51 & 6,4 & 6,68 & 7 & $\mathrm{COM}$ \\
\hline 2.6 .2 .0 .7 & Engineering and architecture researchers and lab assistants & 6,67 & 6,68 & 6,86 & 7 & $\mathrm{COM}$ \\
\hline 2.6.2.0.8 & $\begin{array}{l}\text { Antiquity, philology, history, philosophy, pedagogy, psychology } \\
\text { and law researchers and lab assistants }\end{array}$ & 6,71 & 6,86 & 6,99 & 7 & COM \\
\hline 2.6.2.0.9 & $\begin{array}{l}\text { Statistics, economics and political sciences researchers and lab } \\
\text { assistants }\end{array}$ & 6,53 & 6,51 & 6,79 & 7 & $\mathrm{COM}$ \\
\hline 2.6 .3 .1 .1 & Art schools professors & 6,37 & 6 & 6,34 & 6 & EXP \\
\hline 2.6 .3 .1 .2 & Music schools professors & 6,55 & 5,81 & 6,87 & 6 & $\mathrm{COM}$ \\
\hline 2.6 .3 .1 .3 & Drama and dance schools professors & 6,28 & 5,94 & 6,57 & 6 & $\mathrm{COM}$ \\
\hline 2.6.3.2.1 & Mathematical, physical and chemical sciences professors & 6,12 & 5,81 & 6,21 & 6 & $\mathrm{COM}$ \\
\hline
\end{tabular}




\begin{tabular}{|c|c|c|c|c|c|c|}
\hline 2.6 .3 .2 .2 & Natural sciences professors & 5,6 & 5,32 & 25,59 & 6 & EXP \\
\hline 2.6.3.2.3 & Technical disciplines professors & 6,08 & - & 6,34 & 6 & $\mathrm{COM}$ \\
\hline 2.6.3.2.4 & Information sciences professors & 6,49 & 6,4 & 6,61 & 7 & $\mathrm{COM}$ \\
\hline 2.6.3.2.5 & $\begin{array}{c}\text { Literature, arts, history, philosophy, pedagogy and psychology } \\
\text { professors }\end{array}$ & 6,73 & 6,43 & 6,49 & 7 & EXP \\
\hline 2.6 .3 .2 .6 & Social sciences professors & 5,47 & 5,38 & 5,59 & 5 & $\mathrm{COM}$ \\
\hline 2.6.3.3.1 & Humanistic disciplines professors & 6,34 & 6,08 & 6,32 & 6 & EXP \\
\hline 2.6.3.3.2 & Technical and scientific disciplines professors & 5,55 & 5,04 & 5,42 & 5 & EXP \\
\hline 2.6.4.1.0 & Primary school teachers & 5,96 & 5,76 & 6 & 6 & $\mathrm{COM}$ \\
\hline 2.6.4.2.0 & Pre-primary school teachers & 5,04 & 5,16 & 5,06 & 5 & NON-G \\
\hline 2.6.5.1.0 & Specialists in education and training of disabled & 5,94 & 5,6 & 5,73 & 6 & EXP \\
\hline 2.6.5.2.0 & School and other educational establishments principals & 6,11 & 6,32 & 6,16 & 6 & STR \\
\hline 2.6.5.3.0 & Technical managers in public education establishments & 6,83 & 6,48 & 6,56 & 7 & EXP \\
\hline 2.6.5.4.1 & VET teachers & 6,48 & 6,13 & 6,43 & 6 & EXP \\
\hline 2.6 .5 .4 .2 & Training planners & 6,72 & 5,9 & 6,09 & 6 & EXP \\
\hline 2.6 .5 .5 .0 & Guidance tutors & 6,24 & 6,2 & 6,05 & 6 & EXP \\
\hline 3.1 .1 .1 .1 & Geological technicians & 5,2 & 5,23 & 5,25 & 5 & NON-G \\
\hline 3.1 .1 .1 .2 & Nuclear technicians & 6 & 5,82 & 5,6 & 6 & EXP \\
\hline 3.1 .1 .1 .3 & Renewable energies and energy conservation technicians & 4,72 & 4,71 & 4,56 & 5 & NON-G \\
\hline 3.1 .1 .2 .0 & Chemical technicians & 5,41 & 5,06 & 5,07 & 5 & NON-G \\
\hline 3.1 .1 .3 .1 & IT technicians & 6,09 & 5,55 & 5,49 & 6 & EXP \\
\hline 3.1 .1 .3 .2 & Hardware techinicians & 6,1 & 5,26 & 5,17 & 6 & EXP \\
\hline 3.1 .1 .3 .3 & IT and network management consultants & 5,7 & 5,31 & 5,2 & 5 & EXP \\
\hline 3.1 .1 .3 .4 & Database technicians & 5,71 & 5,36 & 5,07 & 5 & EXP \\
\hline 3.1 .1 .3 .5 & Application consultants & 6,36 & 5,96 & 5,88 & 6 & EXP \\
\hline 3.1 .1 .4 .0 & Statistical techinicians & 5,3 & 5,28 & 5,26 & 5 & NON-G \\
\hline 3.1 .2 .1 .0 & Mechanical technicians & 4,93 & 4,88 & 4,91 & 5 & NON-G \\
\hline 3.1 .2 .2 .1 & Ceramic tiles production technicians & 5,64 & 5,34 & 5,12 & 5 & EXP \\
\hline 3.1 .2 .2 .2 & Mining techinicians & 5,07 & 4,76 & 5,22 & 5 & NON-G \\
\hline 3.1 .2 .2 .3 & Metallurgical techinicians & 5,57 & 5,56 & 5,52 & 6 & EXP \\
\hline 3.1 .2 .3 .0 & Electronic equipment technicians & 5,39 & 5,13 & 5,12 & 5 & NON-G \\
\hline 3.1 .2 .4 .0 & Electronic techinicians & 6,05 & 5,65 & 5,68 & 6 & EXP \\
\hline 3.1 .2 .5 .1 & Civil engineering technicians & 5,25 & 4,85 & 4,96 & 5 & NON-G \\
\hline 3.1 .2 .5 .2 & Civil engineering mappers and planners & 5,59 & 5,61 & 5,63 & 6 & $\mathrm{COM}$ \\
\hline 3.1 .2 .6 .1 & Design techinicians & 4,99 & 5,06 & 5,09 & 5 & NON-G \\
\hline 3.1 .2 .6 .2 & Textile designers & 5,2 & 5,02 & 4,76 & 5 & NON-G \\
\hline 3.1 .2 .9 .0 & Production process technicians & 5,84 & 5,66 & 5,6 & 6 & EXP \\
\hline 3.1 .3 .1 .1 & Naval commanders & 5,72 & 5,15 & 5,2 & 5 & EXP \\
\hline 3.1 .3 .1 .2 & Cabin officers, attendants and stewards & 5 & 4,75 & 4,83 & 5 & NON-G \\
\hline 3.1 .3 .1 .3 & Naval pilots & 4,99 & 5,1 & 4,84 & 5 & NON-G \\
\hline 3.1 .3 .2 .1 & Aircraft pilots and officers & 6,58 & 6,24 & 6,4 & 6 & EXP \\
\hline 3.1.3.2.2 & Avionic technicians & 5,88 & 5,81 & 5,68 & 6 & EXP \\
\hline 3.1.3.2.3 & Aerospace engineering technicians & 6,82 & - & 6,84 & 7 & $\mathrm{COM}$ \\
\hline
\end{tabular}




\begin{tabular}{|c|c|c|c|c|c|c|}
\hline 3.1.3.3.1 & Air traffic controllers & 5,79 & 5,66 & 6,11 & 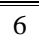 & COM \\
\hline 3.1.3.3.2 & Air traffic service assistants & 6,4 & 6,29 & 6,45 & 6 & $\mathrm{COM}$ \\
\hline 3.1 .4 .1 .0 & Photographers & 5,79 & 5,28 & 5,12 & 5 & EXP \\
\hline 3.1 .4 .2 .1 & Radio operators & 3,6 & 3,63 & 4,15 & 4 & NON-G \\
\hline 3.1 .4 .2 .2 & Tecnici delle trasmissioni radio-televisive & 4,88 & 4,88 & 4,79 & 5 & NON-G \\
\hline 3.1.4.3.1 & $\begin{array}{c}\text { Tecnici degli apparati audio-video e della ripresa video- } \\
\text { cinematografica }\end{array}$ & 5,42 & 5,36 & 4,88 & 5 & NON-G \\
\hline 3.1 .4 .3 .2 & Tecnici del suono & 5,82 & 5,37 & 5,28 & 5 & EXP \\
\hline 3.1 .4 .3 .3 & Tecnici del montaggio audio-video-cinematografico & 5,29 & 5,09 & 5,12 & 5 & NON-G \\
\hline 3.1 .4 .4 .0 & Tecnici di apparati medicali e per la diagnostica medica & 4,56 & 4,51 & 4,45 & 5 & NON-G \\
\hline 3.1 .4 .9 .0 & Altri operatori di apparati ottici ed elettronici & 5,3 & 4,94 & 5,04 & 5 & NON-G \\
\hline 3.1 .5 .1 .2 & Tecnici della sicurezza sul lavoro & 5,79 & 5,62 & 5,71 & 6 & EXP \\
\hline 3.1 .5 .2 .0 & Tecnici del controllo della qualità industriale & 5,76 & 5,41 & 5,21 & 5 & EXP \\
\hline 3.1 .5 .3 .0 & Tecnici del controllo ambientale & 5,32 & 5,18 & 5,38 & 5 & NON-G \\
\hline 3.1 .5 .4 .1 & Tecnici della raccolta e dello smaltimento dei rifiuti & 5,08 & 4,97 & 4,96 & 5 & NON-G \\
\hline 3.1.5.4.2 & $\begin{array}{l}\text { Tecnici del trattamento e della gestione delle acque reflue e } \\
\text { potabili }\end{array}$ & 4,68 & 4,63 & 4,62 & 5 & NON-G \\
\hline 3.2 .1 .1 .1 & Infermieri & 5,95 & 5,73 & 5,79 & 6 & EXP \\
\hline 3.2 .1 .1 .2 & Tecnici di diagnostica & 5,56 & 4,82 & 5,31 & 5 & EXP \\
\hline 3.2 .1 .2 .1 & Ortottisti e assistenti di oftalmologia & 5,18 & 5,19 & 5,41 & 5 & NON-G \\
\hline 3.2 .1 .2 .2 & Ottici e optometristi & 5,44 & 4,77 & 5,04 & 5 & NON-G \\
\hline 3.2 .1 .3 .1 & Igienisti dentali & 5,74 & 5,52 & 5,55 & 6 & EXP \\
\hline 3.2 .1 .3 .2 & Odontotecnici & 5,52 & 5,2 & - & 5 & EXP \\
\hline 3.2 .1 .4 .1 & Fisioterapisti e tecnici della riabilitazione & 4,96 & 5,18 & 5,05 & 5 & NON-G \\
\hline 3.2 .1 .4 .2 & Tecnici protesici & 5,39 & 5,26 & 5,34 & 5 & NON-G \\
\hline 3.2 .1 .5 .0 & Levatrici e ostetriche & 5,9 & 5,86 & 5,78 & 6 & EXP \\
\hline 3.2 .1 .6 .1 & Dietisti & 5,63 & 5,63 & 5,59 & 6 & EXP \\
\hline 3.2 .1 .6 .2 & Tecnici della nutrizione & 5,12 & 5,31 & 5,36 & 5 & NON-G \\
\hline 3.2 .1 .7 .1 & Tecnici della prevenzione sanitaria & 5,6 & 5,56 & 5,53 & 6 & EXP \\
\hline 3.2.1.7.2 & Tecnici dell'assistenza sanitaria & 5,92 & 5,64 & 5,79 & 6 & EXP \\
\hline 3.2 .1 .9 .0 & Tecnici della medicina popolare ed altri tecnici paramedici & 5,12 & 4,96 & 5,28 & 5 & NON-G \\
\hline 3.2 .2 .1 .1 & Tecnici agronomi & 5,42 & 4,96 & 5,2 & 5 & NON-G \\
\hline 3.2 .2 .1 .2 & Tecnici forestali & 5,6 & 5,63 & 5,6 & 6 & STR \\
\hline 3.2 .2 .2 .0 & Zootecnici & 5,63 & 5,32 & 5,44 & 5 & EXP \\
\hline 3.2 .2 .3 .1 & Tecnici di laboratorio di analisi cliniche & 4,72 & 4,5 & 4,4 & 5 & NON-G \\
\hline 3.2 .2 .3 .2 & Tecnici di laboratorio biochimico & 6,41 & 5,84 & 6,4 & 6 & EXP \\
\hline 3.2 .2 .3 .3 & Tecnici dei prodotti alimentari & 5,63 & 5,52 & 5,28 & 5 & EXP \\
\hline 3.2 .2 .3 .4 & Tecnici di laboratorio veterinario & 5,28 & 4,9 & 5,42 & 5 & NON-G \\
\hline 3.3 .1 .1 .1 & Segretari amministrativi e tecnici degli affari generali & 5,38 & 5,2 & 5,37 & 5 & NON-G \\
\hline 3.3 .1 .1 .2 & Assistenti di archivio e di biblioteca & 5,15 & 4,88 & 5,52 & 5 & $\mathrm{COM}$ \\
\hline 3.3 .1 .2 .1 & Contabili & 5,82 & 5,45 & 5,6 & 6 & EXP \\
\hline 3.3 .1 .2 .2 & Economi e tesorieri & 5,84 & 5,98 & 5,48 & 6 & STR \\
\hline 3.3 .1 .2 .3 & Amministratore di stabili e condomini & 5,57 & 5,15 & 5,33 & 5 & EXP \\
\hline
\end{tabular}




\begin{tabular}{|c|c|c|c|c|c|c|}
\hline 3.3.1.3.0 & $\begin{array}{l}\text { Tecnici addetti all'organizzazione e al controllo gestionale della } \\
\text { produzione. }\end{array}$ & 5,68 & 5,26 & 5,2 & 5 & EXP \\
\hline 3.3 .1 .4 .1 & Tecnici dell'acquisizione delle informazioni & 5,28 & 5,1 & 5,41 & 5 & NON-G \\
\hline 3.3 .1 .4 .2 & IntervISTATori e rilevatori professionali & 4,06 & 4,35 & 4,72 & 4 & NON-G \\
\hline 3.3 .1 .5 .0 & Corrispondenti in lingue estere e assimilati & 5,76 & 5,23 & 5,63 & 6 & EXP \\
\hline 3.3 .2 .1 .1 & Tecnici della gestione finanziaria aziendale & 5,76 & 5,68 & 5,57 & 6 & EXP \\
\hline 3.3 .2 .1 .2 & Consulenti finanziari & 6,12 & 5,88 & 6,19 & 6 & $\mathrm{COM}$ \\
\hline 3.3 .2 .2 .0 & Tecnici del lavoro bancario & 5,36 & 5,39 & 5,49 & 5 & NON-G \\
\hline 3.3 .2 .3 .0 & Agenti assicurativi & - & 5,63 & 5,87 & 6 & $\mathrm{COM}$ \\
\hline 3.3 .2 .4 .1 & Periti stimatori di danno & 4,94 & 5,04 & 5,36 & 5 & NON-G \\
\hline 3.3.2.4.2 & Valutatori di rischio & 6,08 & 5,79 & 5,8 & 6 & EXP \\
\hline 3.3 .2 .4 .3 & Liquidatori & 5,6 & 5,52 & 5,72 & 6 & $\mathrm{COM}$ \\
\hline 3.3.2.5.0 & $\begin{array}{l}\text { Agenti di borsa e cambio, tecnici dell'intermediazione titoli ed } \\
\text { assimilati }\end{array}$ & 5,36 & 5,34 & 5,52 & 5 & $\mathrm{COM}$ \\
\hline 3.3 .2 .9 .2 & Tecnici della locazione finanziaria & 5,92 & 5,87 & 5,87 & 6 & EXP \\
\hline 3.3.3.1.0 & Approvvigionatori e responsabili acquisti & 4,84 & 5,12 & 5,25 & 5 & NON-G \\
\hline 3.3.3.2.0 & Responsabili di magazzino e della distribuzione interna & 4,08 & 4,14 & 4,13 & 4 & NON-G \\
\hline 3.3 .3 .3 .1 & Commissari e aggiudicatori d'asta & 5,12 & 5,24 & 5,23 & 5 & NON-G \\
\hline 3.3.3.3.2 & Periti commerciali & 4,88 & 5,22 & 5,11 & 5 & NON-G \\
\hline 3.3 .3 .4 .0 & Tecnici della vendita e della distribuzione & 4,88 & 5,12 & 5,12 & 5 & NON-G \\
\hline 3.3 .3 .5 .0 & Tecnici del marketing & 6 & 6,22 & 6,23 & 6 & $\mathrm{COM}$ \\
\hline 3.3 .3 .6 .1 & Tecnici della pubblicità & 5,7 & 5,57 & 5,79 & 6 & $\mathrm{COM}$ \\
\hline 3.3 .3 .6 .2 & Tecnici delle pubbliche relazioni & 6,42 & 6,34 & 6,6 & 6 & $\mathrm{COM}$ \\
\hline 3.3 .4 .1 .1 & Agenti e spedizionieri & 5,92 & 5,43 & 5,46 & 6 & EXP \\
\hline 3.3 .4 .1 .2 & Tecnici dell'organizzazione commerciale & 5,52 & 6 & 5,86 & 6 & STR \\
\hline 3.3 .4 .2 .0 & Agenti di commercio & - & 5,03 & 5,37 & 5 & NON-G \\
\hline 3.3 .4 .3 .0 & Agenti concessionari & 5,2 & 5,28 & 5,59 & 5 & $\mathrm{COM}$ \\
\hline 3.3.4.4.0 & Agenti di pubblicità & 5,47 & 5,52 & 5,82 & 6 & $\mathrm{COM}$ \\
\hline 3.3 .4 .5 .1 & Agenti immobiliari & - & 5,32 & 5,49 & 5 & NON-G \\
\hline 3.3 .4 .5 .2 & Periti immobiliari & 5,68 & 6 & 6,07 & 6 & $\mathrm{COM}$ \\
\hline 3.3 .4 .6 .0 & Rappresentanti di commercio & 4,88 & 4,95 & 5,24 & 5 & NON-G \\
\hline 3.3 .4 .9 .0 & Agenti e rappresentanti di artisti ed atleti & 5,28 & 5,68 & 6,05 & 6 & $\mathrm{COM}$ \\
\hline 3.4 .1 .1 .0 & Tecnici delle attività ricettive ed assimilati & - & 5,28 & 5,56 & 5 & $\mathrm{COM}$ \\
\hline 3.4 .1 .2 .1 & Organizzatori di fiere ed esposizioni & 5,92 & 5,87 & 6,03 & 6 & $\mathrm{COM}$ \\
\hline 3.4 .1 .2 .2 & Organizzatori di convegni e ricevimenti & 5,84 & 6,19 & 6,32 & 6 & $\mathrm{COM}$ \\
\hline 3.4.1.3.0 & Animatori turistici ed assimilati & 4,82 & 5,15 & 5,12 & 5 & NON-G \\
\hline 3.4.1.4.0 & Agenti di viaggio & 6 & 5,4 & 5,47 & 6 & EXP \\
\hline 3.4 .1 .5 .1 & Guide ed accompagnatori sportivi & 5,47 & 5,14 & 5,35 & 5 & NON-G \\
\hline 3.4 .1 .5 .2 & Guide ed accompagnatori turistici & 5,34 & 5,08 & 5,31 & 5 & NON-G \\
\hline 3.4 .2 .1 .0 & Insegnanti elementari & 5,56 & 5,39 & 5,51 & 5 & EXP \\
\hline 3.4.2.2.0 & $\begin{array}{l}\text { Insegnanti per soggetti diversamente abili, di sostegno e altri } \\
\text { insegnanti di scuole speciali }\end{array}$ & 5,39 & 5,5 & 5,43 & 5 & STR \\
\hline 3.4 .2 .3 .1 & Insegnanti di asili nido & 4,61 & 4,73 & 5,03 & 5 & NON-G \\
\hline
\end{tabular}




\begin{tabular}{|c|c|c|c|c|c|c|}
\hline 3.4 .2 .3 .2 & Insegnanti di scuole materne & 4,79 & 5,09 & 4,97 & 5 & NON-G \\
\hline 3.4.2.4.1 & Tutor, istitutori e insegnanti nella formazione professionale & 5,36 & 5,15 & 5,31 & 5 & NON-G \\
\hline 3.4 .2 .4 .2 & Insegnanti tecnico-pratici negli istituti di istruzione secondaria & 5,77 & 5,36 & 5,77 & 6 & COM \\
\hline 3.4 .3 .1 .1 & Istruttori di volo & 5,84 & 5,89 & 6,05 & 6 & $\mathrm{COM}$ \\
\hline 3.4 .3 .1 .2 & Istruttori di guida automobilistica & 5,08 & 4,89 & 5,2 & 5 & NON-G \\
\hline 3.4 .3 .1 .3 & Istruttori di nautica & 5,31 & 5,02 & 5,54 & 5 & COM \\
\hline 3.4.3.2.1 & Istruttori di arti figurative & 5,78 & 5,16 & 5,96 & 6 & $\mathrm{COM}$ \\
\hline 3.4 .3 .2 .2 & Istruttori di danza & 5,9 & 5,36 & 5,97 & 6 & COM \\
\hline 3.4 .3 .2 .3 & Istruttori di canto & 5,41 & 5,38 & 5,68 & 5 & COM \\
\hline 3.4 .3 .2 .4 & Istruttori di strumenti musicali & 6,06 & 5,44 & 5,87 & 6 & EXP \\
\hline 3.4 .3 .2 .5 & Istruttori in campo linguistico & 6,3 & 6,04 & 6,15 & 6 & EXP \\
\hline 3.4 .3 .3 .0 & Istruttori di discipline sportive non agonistiche & 5,12 & 4,94 & 5,15 & 5 & NON-G \\
\hline 3.4 .3 .4 .1 & Organizzatori di eventi e di strutture sportive & 5,12 & 5,11 & 5,23 & 5 & NON-G \\
\hline 3.4.3.4.2 & Osservatori sportivi & 6,24 & 5,58 & 5,78 & 6 & EXP \\
\hline 3.4 .3 .5 .1 & Allenatori e tecnici sportivi & 4,92 & 5,05 & 5,32 & 5 & NON-G \\
\hline 3.4 .3 .5 .2 & Arbitri e giudici di gara & 4,61 & 5,02 & 4,82 & 5 & NON-G \\
\hline 3.4 .3 .6 .0 & Atleti & 4,44 & 4,45 & 4,69 & 5 & NON-G \\
\hline 3.4 .4 .1 .1 & Annunciatori della radio e della televisione & 5,3 & 4,94 & 5,51 & 5 & COM \\
\hline 3.4 .4 .1 .2 & Presentatori di performance artistiche e ricreative & 5,23 & 4,9 & 5,98 & 5 & COM \\
\hline 3.4 .4 .2 .1 & Grafici pubblicitari & 6,18 & 5,84 & 5,9 & 6 & EXP \\
\hline 3.4 .4 .2 .2 & Disegnatori di moda & 5,12 & 4,63 & 4,61 & 5 & NON-G \\
\hline 3.4 .4 .2 .3 & Disegnatori e allestitori di scena & 5,63 & 5,3 & 5,18 & 5 & EXP \\
\hline 3.4 .4 .2 .4 & Disegnatori commerciali ed industriali & 5,46 & 5,12 & 4,86 & 5 & NON-G \\
\hline 3.4 .4 .2 .5 & Disegnatori artistici e illustratori & 5,45 & 4,86 & 5,07 & 5 & NON-G \\
\hline 3.4 .4 .3 .1 & Tecnici dei musei & 5,15 & 5,04 & 5,26 & 5 & NON-G \\
\hline 3.4 .4 .3 .2 & Tecnici delle biblioteche & 5,06 & 4,82 & 5,06 & 5 & NON-G \\
\hline 3.4 .4 .4 .1 & Stimatori di opere d'arte & 6,21 & 6,1 & 6,04 & 6 & EXP \\
\hline 3.4 .4 .4 .2 & Periti filatelici e numismatici & 5,14 & 5,63 & 5,12 & 6 & STR \\
\hline 3.4 .4 .4 .3 & Periti grafologi ed esperti in analisi e comparazione della scrittura & 5,71 & 6,07 & 6 & 6 & STR \\
\hline 3.4.4.5.0 & $\begin{array}{l}\text { Tecnici dell'organizzazione della produzione radiotelevisiva, } \\
\text { cinematografica e teatrale }\end{array}$ & 5,26 & 5,06 & 5,49 & 5 & NON-G \\
\hline 3.4 .4 .6 .1 & Artisti di strada & 4,87 & 4,74 & 5,25 & 5 & NON-G \\
\hline 3.4 .4 .6 .2 & Artisti di varietà & 4,88 & 4,99 & 5,43 & 5 & NON-G \\
\hline 3.4.4.6.3 & Acrobati e artisti circensi & 5,52 & 4,93 & 5,68 & 5 & COM \\
\hline 3.4 .5 .1 .1 & Assistenti sociali & 5,84 & 6,02 & 6,06 & 6 & COM \\
\hline 3.4 .5 .1 .2 & $\begin{array}{l}\text { Operatori socio-assistenziali e animatori per l'infanzia e la prima } \\
\text { adolescenza }\end{array}$ & 5,2 & 5,55 & 5,73 & 5 & $\mathrm{COM}$ \\
\hline 3.4 .5 .2 .0 & Tecnici del reinserimento e dell'integrazione sociale degli adulti & 6,12 & 6,3 & 6,25 & 6 & STR \\
\hline 3.4.5.3.0 & $\begin{array}{l}\text { Tecnici dei servizi di informazione e di orientamento scolastico e } \\
\text { professionale }\end{array}$ & 5,2 & 5,3 & 5,4 & 5 & NON-G \\
\hline 3.4 .5 .4 .0 & Tecnici dei servizi di collocamento & 5,68 & 6 & 5,9 & 6 & STR \\
\hline 3.4 .5 .5 .0 & Tecnici dei servizi di sicurezza privati e assimilati & 4,96 & 5,2 & 5,12 & 5 & NON-G \\
\hline 3.4.5.6.0 & Tecnici della cura estetica & 4,48 & 4,65 & 4,7 & 5 & NON-G \\
\hline
\end{tabular}




\begin{tabular}{|c|c|c|c|c|c|c|}
\hline 3.4 .6 .1 .0 & "Tecnici dei servizi giudiziari & 5,14 & $4,4,55$ & 5,09 & 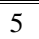 & NON-G \\
\hline 3.4.6.2.0 & Ufficiali della Polizia di Stato & 6 & 5,95 & 6,02 & 6 & COM \\
\hline 3.4 .6 .3 .1 & Comandanti e ufficiali dei vigili urbani & 5,84 & 5,84 & 5,84 & 6 & STR \\
\hline 3.4 .6 .3 .2 & Comandanti e ufficiali dei vigili del fuoco & 7,28 & 6,8 & 6,64 & 7 & EXP \\
\hline 3.4 .6 .3 .3 & Comandanti e ufficiali del corpo forestale & 5,97 & 5,89 & 5,96 & 6 & EXP \\
\hline 3.4 .6 .4 .0 & Ufficiali di finanza & 5,89 & 6,01 & 5,89 & 6 & STR \\
\hline 3.4.6.5.0 & Controllori fiscali & 5,62 & 5,44 & 5,43 & 5 & EXP \\
\hline 3.4.6.6.1 & Tecnici dei servizi pubblici di concessioni licenze & 4,92 & 5,03 & 5,25 & 5 & NON-G \\
\hline 3.4.6.6.2 & $\begin{array}{l}\text { Tecnici dei servizi pubblici per il rilascio di certificazioni e } \\
\text { documentazioni personali }\end{array}$ & 4,74 & 4,44 & 4,68 & 5 & NON-G \\
\hline 4.1.1.1.0 & Dattilografi, stenodattilografi & 4,49 & 4,2 & 4,31 & 4 & NON-G \\
\hline 4.1 .1 .2 .0 & Operatori su macchine di calcolo e di elaborazione dati & 5,28 & 4,64 & 5,13 & 5 & NON-G \\
\hline 4.1.1.3.0 & $\begin{array}{l}\text { Operatori su macchine per la riproduzione di documenti e } \\
\qquad \text { assimilati }\end{array}$ & 4,4 & 4,64 & 4,48 & 5 & NON-G \\
\hline 4.1.1.4.0 & Personale di segreteria & 4,76 & 4,6 & 4,94 & 5 & NON-G \\
\hline 4.1 .1 .5 .0 & Personale addetto allo smistamento di materiali e documenti & 4,1 & 4,08 & 4,47 & 4 & NON-G \\
\hline 4.1.1.6.0 & Addetti agli affari generali & 4,72 & 4,21 & 4,55 & 4 & NON-G \\
\hline 4.1 .1 .7 .0 & Addetti alla ricezione di materiali e documenti & 4,94 & 4,48 & 4,26 & 5 & NON-G \\
\hline 4.1.2.1.0 & Aiuto contabili e assimilati & 4,51 & 4,22 & 4,23 & 4 & NON-G \\
\hline 4.1 .2 .2 .0 & Addetti alle rilevazioni di dati amministrativi & 4,51 & 4,23 & 4,34 & 4 & NON-G \\
\hline 4.1 .2 .3 .0 & Addetti a compiti di controllo e verifica & 4,72 & 4,61 & 4,9 & 5 & NON-G \\
\hline 4.1.2.4.0 & $\begin{array}{l}\text { Personale ausiliario nel campo della pianificazione e della } \\
\text { progettazione }\end{array}$ & 4,88 & 4,97 & 5,03 & 5 & NON-G \\
\hline 4.1 .2 .5 .0 & Addetti alla gestione del personale & 4,8 & 4,56 & 4,93 & 5 & NON-G \\
\hline 4.1.2.6.0 & Addetti ai servizi finanziari & 6,04 & 6 & 6,32 & 6 & COM \\
\hline 4.1 .3 .1 .0 & Addetti alla gestione amministrativa dei magazzini & 3,76 & 3,83 & 4,18 & 4 & NON-G \\
\hline 4.1 .3 .2 .0 & Addetti alla gestione amministrativa degli approvvigionamenti & - & 5,28 & 5,25 & 5 & NON-G \\
\hline 4.1 .3 .3 .0 & Addetti alla gestione amministrativa dei trasporti & 4,77 & 4,77 & 4,72 & 5 & NON-G \\
\hline 4.1.3.4.0 & Addetti al controllo della documentazione di viaggio & 3,8 & 4,18 & 4,3 & 4 & NON-G \\
\hline 4.1 .4 .1 .0 & Addetti ad archivi e schedari & 4,32 & - & 4,28 & 4 & NON-G \\
\hline 4.1.4.2.0 & Addetti a biblioteche ed assimilati & 5,09 & 4,66 & 5,05 & 5 & NON-G \\
\hline 4.1.4.3.0 & Addetti a servizi statistici e di documentazione & 5,34 & 5,28 & 5,28 & 5 & NON-G \\
\hline 4.1 .4 .4 .0 & Addetti a servizi Studi e Ricerche & 5,95 & 5,81 & 5,95 & 6 & EXP \\
\hline 4.1 .4 .6 .0 & Addetti alla pubblicizzazione dei testi e della documentazione & 5,26 & 5,17 & 5,6 & 5 & $\mathrm{COM}$ \\
\hline 4.1.4.7.0 & Addetti all'inoltro e allo smistamento di posta e documentazione & 2,96 & 3,16 & 3,85 & 3 & NON-G \\
\hline 4.1.4.8.0 & $\begin{array}{l}\text { Addetti a telescriventi e ad altri mezzi di diffusione telematica } \\
\text { della documentazione }\end{array}$ & 5,48 & 5,33 & 5,52 & 5 & $\mathrm{COM}$ \\
\hline 4.2 .1 .1 .1 & Cassieri & 5,56 & 5,87 & 6,21 & 6 & $\mathrm{COM}$ \\
\hline 4.2 .1 .1 .2 & Bigliettai & 3,3 & 3,89 & 3,64 & 4 & NON-G \\
\hline 4.2 .1 .2 .0 & Addetti allo sportello bancario & 4,68 & 4,86 & 4,84 & 5 & NON-G \\
\hline 4.2 .1 .3 .0 & Addetti a sportelli assicurativi e assimilati & 5,16 & 5,44 & 5,27 & 5 & NON-G \\
\hline 4.2 .1 .4 .0 & Addetti allo sportello di altri intermediari finanziari & 4,42 & 4,56 & 4,92 & 5 & NON-G \\
\hline 4.2 .1 .5 .0 & Esattori di fatture e di crediti & 5,34 & 5,06 & 5,27 & 5 & NON-G \\
\hline
\end{tabular}




\begin{tabular}{|c|c|c|c|c|c|c|}
\hline 4.2 .1 .6 .0 & Addetti ad agenzie di pegno e assimilati & 5,57 & 5,61 & 5,41 & 6 & STR \\
\hline 4.2.1.7.1 & Allibratori & 4,4 & 4,73 & 4,52 & 5 & NON-G \\
\hline 4.2 .1 .7 .2 & Croupiers & 4,72 & 5,28 & 4,9 & 5 & NON-G \\
\hline 4.2 .1 .7 .3 & Ricevitori & 3,92 & 4,04 & 4,16 & 4 & NON-G \\
\hline 4.2 .2 .1 .0 & Addetti all'accoglienza ed assimilati & 4,08 & 4,46 & 4,42 & 4 & NON-G \\
\hline 4.2 .2 .2 .0 & Addetti ad uffici stampa ed assimilati & 5,57 & 4,8 & 5,4 & 5 & EXP \\
\hline 4.2 .2 .3 .1 & Centralinisti & 3,34 & 3,96 & 3,99 & 4 & NON-G \\
\hline 4.2 .2 .3 .2 & Telefonisti e addetti ai Call Center & 3,84 & 3,92 & 4,2 & 4 & NON-G \\
\hline 4.2 .2 .4 .1 & Assistenti di volo & 5,44 & 5,84 & 5,44 & 6 & STR \\
\hline 4.2 .2 .4 .2 & Assistenti di viaggio e crociera & 5,32 & 5,54 & 5,5 & 5 & STR \\
\hline 4.2 .2 .4 .3 & Assistenti congressuali e fieristici & 4,12 & 4,38 & 4,48 & 4 & NON-G \\
\hline 5.1 .1 .1 .0 & Esercenti e gestori delle vendite all'ingrosso & 4,48 & 4,77 & 4,92 & 5 & NON-G \\
\hline 5.1 .1 .2 .0 & Addetti ad attività organizzative delle vendite all'ingrosso & 3,83 & 4,4 & 4,34 & 4 & NON-G \\
\hline 5.1 .1 .3 .0 & Addetti alle vendite all'ingrosso & - & 5,11 & 5,34 & 5 & NON-G \\
\hline 5.1 .2 .1 .0 & Commessi e assimilati & 3,52 & 4,18 & 4,22 & 4 & NON-G \\
\hline 5.1 .2 .2 .0 & Esercenti delle vendite al minuto & 4,4 & 4,71 & 4,89 & 5 & NON-G \\
\hline 5.1 .2 .3 .0 & Esercenti di distributori di carburanti ed assimilati & - & 4,31 & 4,19 & 4 & NON-G \\
\hline 5.1 .2 .4 .0 & Addetti ai distributori di carburanti ed assimilati & 3,12 & 3,2 & 3,3 & 3 & NON-G \\
\hline 5.1 .2 .5 .1 & Venditori a domicilio & 4,8 & 4,97 & 5,13 & 5 & NON-G \\
\hline 5.1 .2 .5 .2 & Venditori a distanza & 4,72 & 4,77 & 5,01 & 5 & NON-G \\
\hline 5.1 .2 .6 .0 & Cassieri di esercizi commerciali & 3,31 & 3,41 & 3,79 & 4 & NON-G \\
\hline 5.1 .3 .1 .0 & Indossatori, modelli e assimilati & 4,24 & 4,49 & 5,25 & 5 & NON-G \\
\hline 5.1 .3 .2 .0 & Dimostratori ed assimilati & 3,92 & 4,45 & 5,06 & 4 & NON-G \\
\hline 5.1 .3 .3 .0 & Vetrinisti ed assimilati & 4,67 & 4,8 & 4,78 & 5 & NON-G \\
\hline 5.1 .3 .4 .0 & Addetti all'informazione e all'assistenza dei clienti & - & 5,22 & 5,03 & 5 & NON-G \\
\hline 5.2 .1 .1 .0 & Esercenti e gestori di servizi alberghieri ed assimilati & 5,04 & 5,1 & 5,04 & 5 & NON-G \\
\hline 5.2 .1 .2 .0 & Esercenti e gestori di servizi extralberghieri ed assimilati & - & 4,82 & 4,98 & 5 & NON-G \\
\hline 5.2 .1 .3 .0 & Addetti all'accoglimento, portieri di albergo ed assimilati & 4,44 & 4,46 & 4,77 & 5 & NON-G \\
\hline 5.2 .2 .1 .0 & Cuochi in alberghi e ristoranti & 3,84 & 3,84 & 3,79 & 4 & NON-G \\
\hline 5.2 .2 .2 .1 & Cuochi di imprese per la ristorazione collettiva & 4,38 & 4,35 & 4,34 & 4 & NON-G \\
\hline 5.2 .2 .2 .2 & Cuochi di fast food & 4,24 & 4,48 & 4,48 & 4 & NON-G \\
\hline 5.2 .2 .2 .3 & Addetti e confezionatori nella ristorazione collettiva & 3,01 & 2,75 & 3,15 & 3 & NON-G \\
\hline 5.2 .2 .3 .1 & Camerieri di albergo & 3,08 & 3,63 & 3,26 & 3 & NON-G \\
\hline 5.2 .2 .3 .2 & Camerieri di ristorante & 3,73 & 3,93 & 4 & 4 & NON-G \\
\hline 5.2 .2 .3 .3 & Camerieri di mensa e fast food & 3,44 & 3,89 & 3,85 & 4 & NON-G \\
\hline 5.2 .2 .4 .0 & Baristi e assimilati & 3,68 & 4,06 & 4,16 & 4 & NON-G \\
\hline 5.2 .2 .5 .0 & Esercenti di servizi di ristorazione ed assimilati & - & 4,89 & 5,02 & 5 & NON-G \\
\hline 5.3 .1 .1 .0 & Maestri d'arte nel campo dell'artigianato & 5,17 & 4,96 & 5,46 & 5 & NON-G \\
\hline 5.3.1.2.0 & $\begin{array}{l}\text { Maestri di attività per il tempo libero, la cura della persona e } \\
\text { assimilati }\end{array}$ & 5,02 & 4,5 & 4,99 & 5 & NON-G \\
\hline 5.3 .1 .3 .1 & Addestratori di animali & 4,6 & 4,98 & 5,09 & 5 & NON-G \\
\hline 5.3 .1 .3 .2 & Custodi e allevatori di animali domestici e da esposizione & 3,36 & 3,69 & 3,69 & 4 & NON-G \\
\hline 5.4.1.0.0 & Professioni qualificate nei servizi sanitari & 3,79 & 4,28 & 4,56 & 4 & NON-G \\
\hline
\end{tabular}




\begin{tabular}{|c|c|c|c|c|c|c|}
\hline 5.5 .1 .1 .1 & Esercenti e gestori di cinema e teatri & 4,96 & 5,14 & 5,44 & 5 & NON-G \\
\hline 5.5 .1 .1 .2 & Esercenti e gestori di locali notturni & - & 5,17 & 5,48 & 5 & NON-G \\
\hline 5.5 .1 .1 .3 & Esercenti e gestori di attività ricreative & 5,01 & 4,86 & 5,02 & 5 & NON-G \\
\hline $5.5 \cdot 1.1 .4$ & Esercenti e gestori di attività sportive & - & 5,07 & 5,1 & 5 & NON-G \\
\hline $5.5 \cdot 1.2 .0$ & Guide ed accompagnatori urbani & 4,8 & 4,37 & 4,67 & 5 & NON-G \\
\hline 5.5 .2 .1 .0 & Tintori, lavandai e assimilati & 3,8 & 3,82 & 3,71 & 4 & NON-G \\
\hline 5.5 .2 .2 .0 & Esercenti di tintorie, lavanderie e assimilati & 4,24 & 4,58 & 4,43 & 4 & NON-G \\
\hline 5.5 .3 .1 .1 & Parrucchieri e barbieri & 4,44 & 4,21 & 4,33 & 4 & NON-G \\
\hline 5.5 .3 .1 .2 & Estetisti & 5,2 & 4,79 & 4,87 & 5 & NON-G \\
\hline 5.5.3.2.0 & $\begin{array}{l}\text { Personale di compagnia e personale qualificato di servizio alle } \\
\text { famiglie }\end{array}$ & 4,16 & 5,05 & 5,17 & 5 & NON-G \\
\hline 5.5.3.3.0 & Addetti alla sorveglianza di bambini ed assimilati & 3,66 & 4,03 & 4,2 & 4 & NON-G \\
\hline 5.5 .3 .4 .0 & Addetti all'assistenza personale in istituzioni & 4,16 & 4,75 & 5,09 & 5 & NON-G \\
\hline 5.5.3.5.0 & Addetti all'assistenza personale a domicilio & 4,44 & 4,79 & 4,88 & 5 & NON-G \\
\hline 5.5.3.6.0 & Gestori di agenzie per il disbrigo di pratiche ed assimilati & 5,12 & 4,9 & 4,85 & 5 & NON-G \\
\hline 5.5.3.7.0 & Addetti di agenzie per il disbrigo di pratiche ed assimilati & 5,1 & 4,84 & 5,06 & 5 & NON-G \\
\hline 5.5.3.8.0 & Gestori di agenzie di pompe funebri & - & 4,53 & 4,45 & 4 & NON-G \\
\hline 5.5.3.9.0 & Addetti alle agenzie di pompe funebri & 3,76 & 4,1 & 4,2 & 4 & NON-G \\
\hline 5.5.4.1.0 & Personale addetto alla custodia di edifici, impianti ed attrezzature & 3,32 & 3,55 & 3,43 & 3 & NON-G \\
\hline 5.5 .4 .2 .1 & Vigili urbani & 4,91 & 4,72 & 4,85 & 5 & NON-G \\
\hline 5.5.4.2.2 & Personale di guardiania territoriale & 4,77 & 4,99 & 5,02 & 5 & NON-G \\
\hline 5.5 .4 .3 .1 & Agenti della Polizia di Stato & 5,48 & 5,42 & 5,27 & 5 & NON-G \\
\hline 5.5.4.3.2 & Agenti della Guardia di Finanza & 5,2 & 5,12 & 5,22 & 5 & NON-G \\
\hline 5.5.4.3.3 & Agenti del corpo forestale & 4,97 & 4,7 & 4,99 & 5 & NON-G \\
\hline 5.5 .4 .4 .1 & Vigili del fuoco & 6,24 & 6,08 & 5,93 & 6 & EXP \\
\hline 5.5 .4 .4 .2 & Personale delle squadre antincendio & 5,24 & 4,91 & 4,88 & 5 & NON-G \\
\hline 5.5 .4 .5 .0 & Agenti di istituti di pena e rieducazione & 4,46 & 4,67 & 4,72 & 5 & NON-G \\
\hline 5.5.4.6.0 & Guardie private di sicurezza & 4,08 & 4,54 & 4,19 & 4 & NON-G \\
\hline 5.5 .4 .7 .0 & Bagnini e assimilati & 3,6 & 3,99 & 4,25 & 4 & NON-G \\
\hline 5.5.4.8.0 & Gestori di garage ed autorimesse & 3,6 & 3,57 & 3,92 & 4 & NON-G \\
\hline 6.1 .1 .1 .0 & Minatori & 3,23 & 3,76 & 4 & 4 & NON-G \\
\hline 6.1 .1 .2 .0 & Brillatori e artificieri in cave e miniere & 4,29 & 3,92 & 3,92 & 4 & NON-G \\
\hline 6.1 .1 .3 .0 & Tagliatori e levigatori di pietre, scalpellini e marmisti & 3,53 & 3,51 & 3,63 & 4 & NON-G \\
\hline 6.1.1.4.1 & Coltivatori di cave & 3,76 & 3,93 & 4,06 & 4 & NON-G \\
\hline 6.1.1.4.2 & Coltivatori di saline & 4,84 & 4,56 & 4,56 & 5 & NON-G \\
\hline 6.1 .1 .5 .0 & Assistenti e agenti di miniere e cave & 5,31 & 5,04 & 4,93 & 5 & NON-G \\
\hline 6.1.1.6.0 & Armatori e binaristi di miniere e cave & 4,77 & 4,84 & 4,8 & 5 & NON-G \\
\hline 6.1 .2 .1 .0 & Muratori in pietra e mattoni & 4,72 & 3,87 & 4 & 4 & NON-G \\
\hline 6.1.2.2.1 & Armatori e ferraioli & 3,01 & 3,44 & 3,47 & 3 & NON-G \\
\hline 6.1 .2 .2 .2 & Casseronisti/Cassonisti & 4,32 & 3,92 & 3,92 & 4 & NON-G \\
\hline 6.1 .2 .2 .3 & Muratori e formatori in calcestruzzo & 4,8 & 4,03 & 4,43 & 4 & NON-G \\
\hline 6.1.2.3.0 & Carpentieri e falegnami edili & 4,32 & 3,8 & 3,84 & 4 & NON-G \\
\hline 6.1 .2 .4 .0 & Pontatori e ponteggiatori & 5,26 & 5,08 & 5,25 & 5 & NON-G \\
\hline
\end{tabular}




\begin{tabular}{|c|c|c|c|c|c|c|}
\hline 6.1 .2 .5 .2 & Armatori di ferrovie & 3,78 & 3,88 & 3,95 & 4 & NON-G \\
\hline 6.1.2.6.1 & Asfaltisti & 3,31 & 3,06 & 3,06 & 3 & NON-G \\
\hline 6.1 .2 .6 .2 & Lastricatori e pavimentatori stradali & 4,26 & 4,28 & 4,16 & 4 & NON-G \\
\hline 6.1 .2 .9 .0 & Montatori di prefabbricati e di preformati & 4,19 & 3,7 & 3,71 & 4 & NON-G \\
\hline 6.1 .3 .1 .0 & Copritetti e impermeabilizzatori di solai & 5,12 & 4,73 & 4,88 & 5 & NON-G \\
\hline 6.1 .3 .2 .1 & Posatori di pavimenti & 3,88 & 3,76 & 3,88 & 4 & NON-G \\
\hline 6.1.3.2.2 & Rifinitori di pavimenti & 4,36 & 4,37 & 4,25 & 4 & NON-G \\
\hline 6.1.3.2.3 & Piastrellisti e rivestimentisti in pietra e materiali simili & 3,74 & 3,75 & 3,9 & 4 & NON-G \\
\hline 6.1 .3 .3 .0 & Intonacatori & 3,84 & 3,5 & 3,63 & 4 & NON-G \\
\hline 6.1 .3 .4 .0 & Installatori di impianti di isolamento e insonorizzazione & 4,32 & 4,56 & 4,4 & 4 & NON-G \\
\hline 6.1 .3 .5 .0 & Vetrai & 3,86 & 3,81 & 3,84 & 4 & NON-G \\
\hline 6.1 .3 .6 .1 & Idraulici nelle costruzioni civili & 4,88 & 4,7 & 4,48 & 5 & NON-G \\
\hline 6.1.3.6.2 & Installatori di impianti termici nelle costruzioni civili & 4,72 & 4,16 & 4,16 & 4 & NON-G \\
\hline 6.1.3.7.0 & $\begin{array}{l}\text { Elettricisti ed installatori di impianti elettrici nelle costruzioni } \\
\text { civili }\end{array}$ & 4,96 & 4,4 & 4,36 & 5 & NON-G \\
\hline 6.1 .3 .8 .0 & Installatori di infissi e serramenti & 3,84 & 4,05 & 4,42 & 4 & NON-G \\
\hline 6.1.4.1.1 & Pittori edili & 3,76 & 4,01 & 3,93 & 4 & NON-G \\
\hline 6.1 .4 .1 .2 & Decoratori edili e ornatisti & 4,56 & 4,77 & 4,77 & 5 & NON-G \\
\hline 6.1 .4 .1 .3 & Stuccatori & 4,16 & 3,89 & 4,22 & 4 & NON-G \\
\hline 6.1.4.2.0 & $\begin{array}{l}\text { Parchettisti e posatori di pavimenti e rivestimenti sintetici e in } \\
\text { legno }\end{array}$ & 4,88 & 4,62 & 4,63 & 5 & NON-G \\
\hline 6.1 .4 .3 .0 & Pulitori di facciate & 4,36 & 4,11 & 4,21 & 4 & NON-G \\
\hline 6.1 .5 .1 .0 & Operai addetti ai servizi di igiene e pulizia & 4,2 & 3,84 & 3,61 & 4 & NON-G \\
\hline 6.1 .5 .2 .0 & Operai addetti alla manutenzione degli impianti fognari & 4 & 4,01 & 4,02 & 4 & NON-G \\
\hline 6.2 .1 .1 .1 & Fonditori & 4,26 & 3,82 & 4,08 & 4 & NON-G \\
\hline 6.2 .1 .1 .2 & Formatori e animisti & 3,79 & 3,66 & 3,62 & 4 & NON-G \\
\hline 6.2 .1 .2 .0 & Saldatori e tagliatori a fiamma & 2,99 & 3,33 & 3,57 & 3 & NON-G \\
\hline 6.2 .1 .3 .1 & Lattonieri e calderai & 3,68 & 4,03 & 4,21 & 4 & NON-G \\
\hline 6.2 .1 .3 .2 & Tracciatori & 4,88 & 4,48 & 4,49 & 5 & NON-G \\
\hline 6.2 .1 .4 .0 & Carpentieri e montatori di carpenteria metallica & 3,8 & 3,81 & 3,63 & 4 & NON-G \\
\hline 6.2.1.5.0 & $\begin{array}{l}\text { Attrezzatori e montatori di cavi metallici per uso industriale e di } \\
\text { trasporto }\end{array}$ & 4,78 & 4,37 & 4,72 & 5 & NON-G \\
\hline 6.2 .1 .6 .0 & Sommozzatori e lavoratori subacquei & 4,16 & 4,78 & 4,59 & 5 & NON-G \\
\hline 6.2 .1 .7 .0 & Saldatori elettrici e a norme ASME & 3,82 & 3,67 & 3,75 & 4 & NON-G \\
\hline 6.2.1.8.1 & Carrozzieri & 4,64 & 4,38 & 4,35 & 4 & NON-G \\
\hline 6.2 .1 .8 .2 & Stampatori e piegatori di lamiere & 4,26 & 3,98 & 4,1 & 4 & NON-G \\
\hline 6.2 .2 .1 .1 & Fabbri & 4,08 & 4,2 & 4,12 & 4 & NON-G \\
\hline 6.2 .2 .1 .2 & Fucinatori e forgiatori & 4,17 & 3,97 & 4,32 & 4 & NON-G \\
\hline 6.2 .2 .2 .0 & Costruttori di utensili, modellatori e tracciatori meccanici & 4,37 & 4,58 & 4,68 & 5 & NON-G \\
\hline 6.2 .2 .3 .1 & Attrezzisti di macchine utensili & 5,1 & 4,54 & 4,64 & 5 & NON-G \\
\hline 6.2 .2 .3 .2 & Aggiustatori meccanici & 4,88 & 4,35 & 4,56 & 5 & NON-G \\
\hline 6.2 .2 .4 .1 & Rettificatori & 3,87 & 4,05 & 3,78 & 4 & NON-G \\
\hline 6.2 .2 .4 .2 & Levigatori e affilatori di metalli & 4,08 & 3,83 & 3,76 & 4 & NON-G \\
\hline
\end{tabular}




\begin{tabular}{|c|c|c|c|c|c|c|}
\hline 6.2 .3 .1 .1 & Meccanici motoristi e riparatori di veicoli a motore & 5,44 & 4,17 & 4,21 & 5 & NON-G \\
\hline 6.2.3.1.2 & Carburatoristi e pompisti & 4,35 & 4 & 3,97 & 4 & NON-G \\
\hline 6.2 .3 .1 .3 & Radiatoristi & 4,64 & 4,15 & 4,04 & 4 & NON-G \\
\hline 6.2 .3 .1 .4 & Gommisti & 4,56 & 4,51 & 4,56 & 5 & NON-G \\
\hline 6.2 .3 .1 .5 & Meccanici di biciclette e veicoli simili & 4,8 & 4,09 & 4,38 & 5 & NON-G \\
\hline 6.2 .3 .2 .0 & Meccanici, riparatori e manutentori di aerei & 5,22 & 4,8 & 5,18 & 5 & NON-G \\
\hline 6.2.3.3.1 & Riparatori e manutentori di macchinari e impianti industriali & 5,1 & 4,33 & 4,11 & 5 & NON-G \\
\hline 6.2 .3 .3 .2 & Installatori e montatori di macchinari e impianti industriali & 5,12 & 4,7 & 4,88 & 5 & NON-G \\
\hline 6.2 .3 .4 .0 & Frigoristi & 5 & 4,26 & 4,16 & 5 & NON-G \\
\hline 6.2 .3 .5 .1 & Riparatori e manutentori di apparecchi e impianti termoidraulici & 4,05 & 4,36 & 4,13 & 4 & NON-G \\
\hline 6.2 .3 .5 .2 & Installatori e montatori di apparecchi e impianti termoidraulici & 4,45 & 4,43 & 4,32 & 4 & NON-G \\
\hline 6.2 .3 .6 .0 & Meccanici collaudatori & 5,32 & 4,65 & 5,2 & 5 & NON-G \\
\hline 6.2.3.7.0 & Verniciatori artigianali ed industriali & 3,6 & 3,67 & 3,72 & 4 & NON-G \\
\hline 6.2.4.1.1 & Installatori e riparatori di impianti elettrici & 5 & 4,9 & 4,84 & 5 & NON-G \\
\hline 6.2 .4 .1 .2 & Riparatori di apparecchi elettrici e di elettrodomestici & 4,12 & 3,73 & 3,78 & 4 & NON-G \\
\hline 6.2 .4 .1 .3 & Elettromeccanici & 4,16 & 3,8 & 3,84 & 4 & NON-G \\
\hline 6.2.4.1.4 & $\begin{array}{l}\text { Installatori e riparatori di apparati di produzione e conservazione } \\
\text { dell'energia elettrica }\end{array}$ & 5,04 & 4,5 & 4,66 & 5 & NON-G \\
\hline 6.2.4.1.5 & Elettrauto & 4,72 & 4,19 & 4,2 & 4 & NON-G \\
\hline 6.2 .4 .2 .0 & Manutentori e riparatori di apparati elettronici industriali & 5,36 & 4,77 & 4,83 & 5 & NON-G \\
\hline 6.2 .4 .3 .0 & Riparatori di apparecchi radio televisivi & 4,84 & 4,43 & 4,56 & 5 & NON-G \\
\hline 6.2 .4 .4 .0 & Installatori e riparatori di apparati telegrafici e telefonici & 4,76 & 4,29 & 4,24 & 4 & NON-G \\
\hline 6.2 .4 .5 .0 & Installatori, manutentori e riparatori di linee elettriche, cavisti & 4,08 & 4,07 & 4,13 & 4 & NON-G \\
\hline 6.2 .5 .1 .1 & Attrezzisti navali & 3,84 & 3,87 & 3,76 & 4 & NON-G \\
\hline 6.2 .5 .1 .2 & Meccanici e motoristi navali & 5,08 & 3,82 & 3,84 & 4 & NON-G \\
\hline 6.2 .5 .2 .0 & Carpentieri navali & 3,52 & 3,63 & 3,79 & 4 & NON-G \\
\hline 6.2 .5 .3 .0 & Frigoristi navali & 3,82 & 3,89 & 3,74 & 4 & NON-G \\
\hline 6.2 .5 .4 .0 & Elettomeccanici navali & 4,64 & 4,19 & 4,44 & 4 & NON-G \\
\hline 6.3 .1 .1 .1 & Attrezzisti e meccanici di precisione & 4,83 & 4,62 & 4,6 & 5 & NON-G \\
\hline 6.3 .1 .1 .2 & Strumentisti di precisione & 5,04 & 4,94 & 4,92 & 5 & NON-G \\
\hline 6.3.1.2.0 & $\begin{array}{l}\text { Meccanici e riparatori di protesi, di ortesi e di tutori ortopedici e } \\
\qquad \text { simili }\end{array}$ & 5,12 & 5,27 & 5,2 & 5 & NON-G \\
\hline 6.3 .1 .3 .1 & Accordatori di strumenti musicali & 4,77 & 4,7 & 4,53 & 5 & NON-G \\
\hline 6.3 .1 .3 .2 & Addetti alla costruzione e riparazione di strumenti musicali & 4,67 & 4,72 & 4,4 & 5 & NON-G \\
\hline 6.3 .1 .4 .0 & Addetti alla costruzione e riparazione di orologi & 4,26 & 4,29 & 4,16 & 4 & NON-G \\
\hline 6.3 .1 .5 .1 & Addetti alla produzione di lenti e occhiali & 4,3 & 4,11 & 4,3 & 4 & NON-G \\
\hline 6.3 .1 .5 .2 & Addetti alla produzione di apparecchi ottici & 4,58 & 3,95 & 4,21 & 4 & NON-G \\
\hline 6.3 .1 .6 .1 & Orafi e gioiellieri & 4,62 & 4,18 & 4,03 & 4 & NON-G \\
\hline 6.3 .1 .6 .2 & Addetti alla lavorazione di metalli preziosi & 4,46 & 4,22 & 4,32 & 4 & NON-G \\
\hline 6.3 .1 .6 .3 & Addetti alla lavorazione di pietre preziose e dure & 4,81 & 5,03 & 4,6 & 5 & NON-G \\
\hline 6.3 .1 .6 .4 & Addetti alla lavorazione di bigiotteria & 4,56 & 4,31 & 4,62 & 4 & NON-G \\
\hline 6.3 .2 .1 .1 & Vasai e terracottai & 4,11 & 4,08 & 4,22 & 4 & NON-G \\
\hline 6.3 .2 .1 .2 & Ceramisti & 4,68 & 4,28 & 4,44 & 4 & NON-G \\
\hline
\end{tabular}




\begin{tabular}{|c|c|c|c|c|c|c|}
\hline 6.3 .2 .2 .1 & S Soffiatori e modellatori del vetro & 3,92 & 3,64 & 3,49 & 4 & NON-G \\
\hline 6.3.2.2.2 & Tagliatori, molatori e levigatori del vetro & 4,11 & 4,04 & 3,97 & 4 & NON-G \\
\hline 6.3 .2 .3 .0 & Incisori ed acquafortisti su vetro & 3,54 & 3,71 & 3,79 & 4 & NON-G \\
\hline 6.3 .2 .4 .0 & Pittori e decoratori su vetro e ceramica & 4,38 & 4,45 & 3,92 & 4 & NON-G \\
\hline 6.3 .3 .1 .1 & Cartapestai & 5,04 & 4,3 & 4,35 & 5 & NON-G \\
\hline 6.3 .3 .1 .2 & Incisori e intarsiatori su legno & 4,19 & 4,07 & 4,14 & 4 & NON-G \\
\hline 6.3.3.2.1 & Artigiani di prodotti tessili lavorati a mano & 4,34 & 4,34 & 4,83 & 5 & NON-G \\
\hline 6.3 .3 .2 .2 & Artigiani di prodotti in pelle e cuoio lavorati a mano & 4,13 & 3,67 & 3,92 & 4 & NON-G \\
\hline 6.3 .4 .1 .0 & Compositori tipografici & 4,33 & 4,34 & 4,53 & 5 & NON-G \\
\hline 6.3 .4 .2 .0 & Tipografi impressori & 4,48 & 4,1 & 4,1 & 4 & NON-G \\
\hline 6.3 .4 .3 .0 & Stampatori offset e alla rotativa & 3,84 & 3,67 & 3,81 & 4 & NON-G \\
\hline 6.3 .4 .4 .0 & Zincografi, stereotipisti ed elettrotipisti & 3,68 & 3,66 & 3,72 & 4 & NON-G \\
\hline 6.3.4.5.1 & Acquafortisti e serigrafisti & 4,76 & 4,4 & 4,38 & 5 & NON-G \\
\hline 6.3.4.5.2 & Litografi e incisori tipografici & 4,37 & 4,27 & 4,28 & 4 & NON-G \\
\hline 6.3 .4 .6 .0 & Rilegatori e rifinitori post stampa & 3,73 & 3,61 & 3,65 & 4 & NON-G \\
\hline 6.3 .4 .7 .1 & Fototecnici di tipografia & 4,36 & 4,27 & 4,3 & 4 & NON-G \\
\hline 6.3 .4 .7 .2 & Fototipografi e fotocompositori & 4,31 & 4,11 & 4,01 & 4 & NON-G \\
\hline 6.4.1.1.0 & $\begin{array}{l}\text { Agricoltori e operai agricoli specializzati di colture in pieno } \\
\text { campo }\end{array}$ & 4,76 & 3,91 & 3,52 & 4 & NON-G \\
\hline 6.4.1.2.0 & $\begin{array}{l}\text { Agricoltori e operai agricoli specializzati di coltivazioni legnose } \\
\text { agrarie }\end{array}$ & 4,48 & 3,91 & 3,72 & 4 & NON-G \\
\hline 6.4.1.3.1 & $\begin{array}{l}\text { Agricoltori e operai agricoli specializzati di vivai, di coltivazioni } \\
\qquad \text { di fiori e piante ornamentali }\end{array}$ & 3,87 & 3,91 & 3,95 & 4 & NON-G \\
\hline 6.4.1.3.2 & $\begin{array}{l}\text { Agricoltori e operai agricoli specializzati di coltivazioni ortive in } \\
\text { serra, di ortive protette o di orti stabili }\end{array}$ & 4,05 & 3,92 & 3,76 & 4 & NON-G \\
\hline 6.4.1.4.0 & Agricoltori e operai agricoli specializzati di colture miste & 3,79 & 3,63 & 3,64 & 4 & NON-G \\
\hline 6.4.2.1.0 & $\begin{array}{l}\text { Allevatori e operai specializzati degli allevamenti di bovini ed } \\
\text { equini }\end{array}$ & 4,16 & 4,03 & & 4 & NON-G \\
\hline 6.4.2.2.0 & $\begin{array}{l}\text { Allevatori e operai specializzati degli allevamenti di ovini e } \\
\qquad \text { caprini }\end{array}$ & 3,68 & 3,44 & 3,52 & 4 & NON-G \\
\hline 6.4 .2 .3 .0 & Allevatori e operai specializzati degli allevamenti di suini & 4,34 & 4,12 & 4,16 & 4 & NON-G \\
\hline 6.4 .2 .4 .0 & Allevatori e operai specializzati degli allevamenti avicoli & 3,48 & 3,45 & 3,64 & 4 & NON-G \\
\hline 6.4 .2 .5 .0 & Allevatore di bestiame misto & 4 & 3,95 & 4,21 & 4 & NON-G \\
\hline 6.4.2.9.1 & $\begin{array}{l}\text { Allevatori e operai specializzati degli allevamenti di insetti e di } \\
\text { molluschi }\end{array}$ & 4,54 & 4,31 & 3,97 & 4 & NON-G \\
\hline 6.4.2.9.2 & $\begin{array}{l}\text { Allevatori e operai specializzati degli allevamenti di altri animali } \\
\qquad \text { da carne e di animali da pelliccia }\end{array}$ & 5 & 4,82 & 4,64 & 5 & NON-G \\
\hline 6.4.3.0.0 & Allevatori e agricoltori & 4,72 & 4,01 & 3,6 & 4 & NON-G \\
\hline 6.4 .4 .0 .1 & Tagliaboschi, abbattitori di alberi e disboscatori & 3,68 & 3,83 & 3,74 & 4 & NON-G \\
\hline 6.4.4.0.2 & Sugherai e raccoglitori di resine & 4,56 & 4,78 & 4,56 & 5 & NON-G \\
\hline 6.4 .4 .0 .3 & Rimboschitori & 4,16 & 4,13 & 4,26 & 4 & NON-G \\
\hline 6.4 .5 .1 .0 & Acquacoltori & 4,51 & 4,65 & 4,62 & 5 & NON-G \\
\hline 6.4 .5 .2 .0 & Pescatori della pesca costiera e in acque interne & 3,28 & 3,42 & 3,26 & 3 & NON-G \\
\hline 6.4 .5 .3 .0 & Pescatori d'alto mare & 4,22 & 3,92 & 3,96 & 4 & NON-G \\
\hline
\end{tabular}




\begin{tabular}{|c|c|c|c|c|c|c|}
\hline 6.4 .5 .4 .0 & "Cacciatori & 3,87 & 3,77 & 3,73 & 4 & NON-G \\
\hline 6.5 .1 .1 .1 & Macellai e abbattitori di animali & 4,16 & 3,5 & 3,39 & 4 & NON-G \\
\hline 6.5 .1 .1 .2 & Norcini & 4,64 & 4,03 & 4,16 & 4 & NON-G \\
\hline 6.5 .1 .1 .3 & Pesciaioli & 4,44 & 4,19 & 4,22 & 4 & NON-G \\
\hline 6.5 .1 .1 .4 & Addetti alla conservazione di carni e pesci & 4,48 & 3,98 & 3,82 & 4 & NON-G \\
\hline 6.5 .1 .2 .1 & Panettieri & 3,96 & 3,85 & 3,71 & 4 & NON-G \\
\hline 6.5 .1 .2 .2 & Pastai & 4,35 & 4,12 & 4,35 & 4 & NON-G \\
\hline 6.5 .1 .3 .1 & Pasticcieri e cioccolatai & 4,72 & 4,58 & 4,56 & 5 & NON-G \\
\hline $6.5 \cdot 1.3 .2$ & Gelatai & 4,74 & 4,45 & 4,16 & 4 & NON-G \\
\hline 6.5 .1 .3 .3 & Conservieri & 5,09 & 4,63 & 4,92 & 5 & NON-G \\
\hline 6.5 .1 .4 .0 & Degustatori e classificatori di prodotti alimentari e bevande & 5,17 & 5,12 & 4,68 & 5 & NON-G \\
\hline 6.5.1.5.0 & $\begin{array}{c}\text { Artigiani ed operai specializzati delle lavorazioni artigianali } \\
\text { casearie }\end{array}$ & 4,37 & 4,19 & 4,19 & 4 & NON-G \\
\hline 6.5.1.6.0 & $\begin{array}{l}\text { Operai specializzati della preparazione e della lavorazione delle } \\
\qquad \text { foglie di tabacco }\end{array}$ & 3,94 & 3,89 & 3,84 & 4 & NON-G \\
\hline 6.5 .2 .1 .1 & $\begin{array}{c}\text { Stagionatori, ed operai specializzati del primo trattamento del } \\
\text { legno }\end{array}$ & 3,81 & 3,52 & 3,52 & 4 & NON-G \\
\hline 6.5.2.1.2 & $\begin{array}{c}\text { Curvatori, sagomatori ed operai specializzati della prima } \\
\text { lavorazione del legno }\end{array}$ & 3,47 & 2,72 & 2,8 & 3 & NON-G \\
\hline 6.5 .2 .2 .1 & Attrezzisti di falegnameria & 3,48 & 3,56 & 3,28 & 3 & NON-G \\
\hline 6.5 .2 .2 .2 & Falegnami & 4,11 & 3,99 & 4,16 & 4 & NON-G \\
\hline 6.5 .2 .2 .3 & Ebanisti & 3,89 & 3,92 & 3,81 & 4 & NON-G \\
\hline 6.5 .2 .3 .1 & Impagliatori e lavoranti in vimini e setole & 3,25 & 3,31 & 3,42 & 3 & NON-G \\
\hline 6.5 .2 .3 .2 & Cordai e intrecciatori di fibre & 4,72 & 4,38 & 4,24 & 4 & NON-G \\
\hline 6.5 .2 .3 .3 & Lavoranti in giunco e canna & 4,43 & 3,85 & 3,92 & 4 & NON-G \\
\hline 6.5 .2 .3 .4 & Lavoranti in sughero e spugna & 3,8 & 3,42 & 3,5 & 4 & NON-G \\
\hline 6.5 .3 .1 .0 & Preparatori di fibre & 3,84 & 3,44 & 3,2 & 3 & NON-G \\
\hline 6.5 .3 .2 .1 & Tessitori & 4,4 & 4 & 3,87 & 4 & NON-G \\
\hline 6.5 .3 .2 .2 & Maglieristi & 3,5 & 3,65 & 3,73 & 4 & NON-G \\
\hline 6.5 .3 .2 .3 & Tintori e addetti al trattamento chimico dei tessuti & 4,98 & 4,47 & 4,45 & 5 & NON-G \\
\hline 6.5 .3 .3 .1 & Modellisti di capi di abbigliamento & 4,64 & 4,33 & 4,27 & 4 & NON-G \\
\hline 6.5 .3 .3 .2 & Tagliatori e confezionatori di capi di abbigliamento & 3,96 & 4 & 3,97 & 4 & NON-G \\
\hline 6.5 .3 .3 .3 & Sarti & 4,24 & 3,9 & 4,02 & 4 & NON-G \\
\hline 6.5 .3 .3 .4 & Cappellai confezionatori di complementi di abbigliamento & 3,98 & 3,88 & 4,08 & 4 & NON-G \\
\hline 6.5 .3 .4 .1 & Modellisti di pellicceria e di capi in pelle & 4,62 & 4,34 & 4,35 & 4 & NON-G \\
\hline 6.5 .3 .4 .2 & Tagliatori e confezionatori di pellicceria e di capi in pelle & 4,48 & 4,26 & 4,36 & 4 & NON-G \\
\hline 6.5 .3 .4 .3 & Pellicciai e sarti in pelle & 4,26 & 3,97 & 4 & 4 & NON-G \\
\hline 6.5 .3 .5 .1 & Confezionatori e rifinitori di biancheria intima & 4,02 & 4,23 & 4,36 & 4 & NON-G \\
\hline 6.5 .3 .5 .2 & Confezionatori e rifinitori di biancheria per la casa & 3,98 & 4 & 4,19 & 4 & NON-G \\
\hline 6.5 .3 .5 .3 & Merlettai e ricamatrici a mano & 4,27 & 3,79 & 4,07 & 4 & NON-G \\
\hline 6.5 .3 .5 .4 & Bottonai & 4,91 & 4,6 & 4,84 & 5 & NON-G \\
\hline 6.5 .3 .6 .1 & Confezionatori di tende e drappeggi & 3,76 & 3,55 & 3,79 & 4 & NON-G \\
\hline 6.5 .3 .6 .2 & Modellisti di poltrone e divani & 4,29 & 4,23 & 4,2 & 4 & NON-G \\
\hline
\end{tabular}




\begin{tabular}{|c|c|c|c|c|c|c|}
\hline 6.5.3.6.3 & $\begin{array}{l}\text { Tagliatori di imbottiture e rivestimenti e confezionatori di } \\
\text { poltrone e divani }\end{array}$ & 3,66 & 3,71 & 3,57 & 4 & NON-G \\
\hline 6.5 .3 .6 .4 & Tappezzieri di poltrone, divani e simili & 4,03 & 4,04 & 4,1 & 4 & NON-G \\
\hline 6.5 .3 .6 .5 & Materassai & 4,2 & 4,13 & 3,84 & 4 & NON-G \\
\hline 6.5 .4 .1 .0 & Conciatori di pelli e di pellicce & 3,72 & 3,48 & 3,76 & 4 & NON-G \\
\hline 6.5 .4 .2 .1 & Modellisti di calzature & 4,61 & 4,1 & 4,04 & 4 & NON-G \\
\hline 6.5 .4 .2 .2 & Tagliatori e confezionatori di calzature & 3,81 & 3,53 & 3,97 & 4 & NON-G \\
\hline 6.5 .4 .2 .3 & Calzolai & 3,52 & 3,51 & 3,5 & 4 & NON-G \\
\hline 6.5 .4 .2 .4 & Sellai e cuoiai & 3,92 & 3,85 & 3,98 & 4 & NON-G \\
\hline 6.5 .4 .3 .1 & Modellisti di pelletteria & 4,5 & 4,11 & 4 & 4 & NON-G \\
\hline 6.5 .4 .3 .2 & Tagliatori e confezionatori di pelletteria & 3,68 & 3,69 & 3,57 & 4 & NON-G \\
\hline 6.5 .4 .3 .3 & Pellettieri & 4,02 & 3,87 & 3,8 & 4 & NON-G \\
\hline 6.6.1.0.0 & Macchinisti ed attrezzisti di scena & 3,4 & 3,72 & 3,93 & 4 & NON-G \\
\hline 7.1.1.1.0 & Conduttori di impianti di miniere e di cave & 3,34 & 3,33 & 3,58 & 3 & NON-G \\
\hline 7.1 .1 .2 .0 & Conduttori di impianti per il trattamento di minerali e di pietre & 3,68 & 3,89 & 3,79 & 4 & NON-G \\
\hline 7.1 .1 .3 .1 & Trivellatori di pozzi & 4,84 & 4,7 & 4,7 & 5 & NON-G \\
\hline 7.1 .1 .3 .2 & Conduttori di sonde e perforatrici da prospezione & 4,13 & 4,07 & 4,18 & 4 & NON-G \\
\hline 7.1 .2 .1 .1 & Conduttori di altoforno & 4,56 & 4,42 & 4,7 & 5 & NON-G \\
\hline 7.1 .2 .1 .2 & Conduttori di colata & 4,2 & 4,47 & 4,32 & 4 & NON-G \\
\hline 7.1 .2 .2 .1 & Conduttori di forni di seconda fusione & 3,92 & 3,64 & 3,73 & 4 & NON-G \\
\hline 7.1 .2 .2 .2 & Conduttori di laminatoi & 4,34 & 4,33 & 4,41 & 4 & NON-G \\
\hline 7.1 .2 .3 .0 & Conduttori di impianti per il trattamento termico dei metalli & 3,63 & 3,7 & 3,76 & 4 & NON-G \\
\hline 7.1 .2 .4 .1 & Conduttori di macchine per la trafila di metalli & 3,71 & 3,49 & 3,86 & 4 & NON-G \\
\hline 7.1 .2 .4 .2 & Conduttori di macchine per l'estrusione e la profilatura di metalli & 4,42 & 4,39 & 4,54 & 4 & NON-G \\
\hline 7.1.2.5.1 & $\begin{array}{l}\text { Conduttori di impianti termici per la produzione di metalli non } \\
\text { ferrosi }\end{array}$ & 4,03 & 3,7 & 3,76 & 4 & NON-G \\
\hline 7.1.3.1.1 & Conduttori di forni per la produzione del vetro & 4,16 & 4,37 & 4,16 & 4 & NON-G \\
\hline 7.1 .3 .1 .2 & Conduttori di impianti per la lavorazione del vetro & 4,16 & 4,18 & 4,1 & 4 & NON-G \\
\hline 7.1.3.2.1 & $\begin{array}{l}\text { Conduttori di impianti per la formatura di articoli in ceramica e } \\
\text { terracotta }\end{array}$ & 3,84 & 3,71 & 3,76 & 4 & NON-G \\
\hline 7.1.3.2.2 & $\begin{array}{l}\text { Conduttori di forni per la produzione di articoli in ceramica e } \\
\text { terracotta }\end{array}$ & 4,27 & 3,85 & 3,95 & 4 & NON-G \\
\hline 7.1 .3 .3 .1 & Conduttori di impianti per la formatura di laterizi & 3,95 & 3,68 & 3,76 & 4 & NON-G \\
\hline 7.1.3.3.2 & Conduttori di forni per la produzione di laterizi & 3,86 & 3,65 & 3,58 & 4 & NON-G \\
\hline 7.1.3.9.0 & $\begin{array}{l}\text { Conduttori di impianti per dosare, miscelare ed impastare } \\
\text { materiali per la produzione del vetro, della ceramica e dei laterizi }\end{array}$ & 4,36 & 3,9 & 3,8 & 4 & NON-G \\
\hline 7.1.4.1.0 & $\begin{array}{l}\text { Conduttori di impianti per la fabbricazione in serie di pannelli in } \\
\text { legno }\end{array}$ & 3,5 & 3,44 & 3,48 & 4 & NON-G \\
\hline 7.1.4.2.0 & $\begin{array}{l}\text { Conduttori di impianti per la preparazione della pasta di legno e } \\
\qquad \text { di altri materiali per cartiera }\end{array}$ & 4,9 & 4,64 & 4,96 & 5 & NON-G \\
\hline 7.1.4.3.0 & Conduttori di impianti per la fabbricazione della carta & 4,53 & 4,43 & 4,4 & 4 & NON-G \\
\hline 7.1 .5 .1 .0 & Conduttori di frantumatrici, mulini e impastatrici & 4,19 & 3,91 & 3,97 & 4 & NON-G \\
\hline 7.1.5.2.0 & $\begin{array}{l}\text { Conduttori di forni e di impianti per il trattamento termico dei } \\
\text { minerali }\end{array}$ & 4,8 & 4,43 & 4,44 & 5 & NON-G \\
\hline
\end{tabular}




\begin{tabular}{|c|c|c|c|c|c|c|}
\hline 7.1.5.3.0 & Conduttori di apparecchi di filtraggio e di separazione & 4,84 & 4,98 & 4,99 & 5 & NON-G \\
\hline 7.1.5.4.0 & Conduttori di distillatori e di reattori chimici & 5,16 & 5,09 & 5,33 & 5 & NON-G \\
\hline 7.1.5.5.1 & Conduttori di impianti per la raffinazione dei prodotti petroliferi & 4,8 & 4,91 & 5,11 & 5 & NON-G \\
\hline 7.1.5.5.2 & Conduttori di impianti per la stazzatura di prodotti petroliferi & 4,24 & 4,13 & 4,19 & 4 & NON-G \\
\hline 7.1.5.6.0 & Strumentisti e quadristi di impianti chimici & 4,02 & 3,78 & 3,92 & 4 & NON-G \\
\hline 7.1.5.9.0 & Conduttori di impianti per la produzione di prodotti chimici & 4,64 & 3,84 & 4,01 & 4 & NON-G \\
\hline 7.1.6.1.1 & Quadristi di impianti per la produzione di energia elettrica & 4,35 & 4,68 & 4,26 & 4 & NON-G \\
\hline 7.1.6.1.2 & Conduttori di impianti per la produzione di energia elettrica & 4,48 & 4,42 & 4,48 & 4 & NON-G \\
\hline 7.1.6.2.0 & $\begin{array}{l}\text { Conduttori di caldaie a vapore e di motori termici in impianti } \\
\text { industriali }\end{array}$ & 3,84 & 3,89 & 3,92 & 4 & NON-G \\
\hline 7.1.6.4.1 & $\begin{array}{l}\text { Conduttori di impianti per la depurazione, la potabilizzazione e la } \\
\text { distribuzione delle acque }\end{array}$ & 4,16 & 3,63 & 3,6 & 4 & NON-G \\
\hline 7.1.6.4.2 & Conduttori di impianti di incenerimento dei rifiuti & 3,8 & 4,11 & 3,86 & 4 & NON-G \\
\hline 7.1.6.4.3 & Conduttori di impianti di recupero e riciclaggio dei rifiuti & 5,3 & 5,38 & - & 5 & NON-G \\
\hline 7.1.7.1.0 & Conduttori di catene di montaggio automatizzate & 3,92 & 3,84 & 3,88 & 4 & NON-G \\
\hline 7.1.7.2.0 & Conduttori di robot industriali ed assimilati & 3,74 & 3,95 & 4,05 & 4 & NON-G \\
\hline 7.2.1.1.0 & $\begin{array}{l}\text { Conduttori di macchine utensili automatiche e semiautomatiche } \\
\text { industriali }\end{array}$ & 3,71 & 3,49 & 3,6 & 4 & NON-G \\
\hline 7.2.1.2.0 & $\begin{array}{l}\text { Conduttori di macchinari per la produzione di manufatti in } \\
\text { cemento ed affini }\end{array}$ & 3,88 & 3,2 & 3,54 & 4 & NON-G \\
\hline 7.2.1.3.0 & $\begin{array}{l}\text { Conduttori di macchinari per la produzione di abrasivi e } \\
\text { manufatti abrasivi minerali }\end{array}$ & 4,11 & 3,87 & 3,77 & 4 & NON-G \\
\hline 7.2.2.1.1 & Conduttori di macchinari per la produzione di farmaci & 4,22 & 3,82 & 3,77 & 4 & NON-G \\
\hline 7.2 .2 .1 .2 & Conduttori di macchinari per la produzione di cosmetici & 4,02 & 3,48 & 3,5 & 4 & NON-G \\
\hline 7.2.2.1.3 & Conduttori di macchinari per la produzione di detergenti & 4,91 & 4,56 & 4,7 & 5 & NON-G \\
\hline 7.2.2.2.0 & $\begin{array}{l}\text { Conduttori di macchinari per la fabbricazione di esplosivi e } \\
\text { munizioni }\end{array}$ & 5,04 & 4,64 & 4,65 & 5 & NON-G \\
\hline 7.2.2.3.0 & $\begin{array}{l}\text { Finitori di metalli e conduttori di impianti per finire, rivestire, } \\
\text { placcare metalli e oggetti in metallo }\end{array}$ & 4,44 & 4,01 & 4 & 4 & NON-G \\
\hline 7.2.2.9.0 & $\begin{array}{c}\text { Conduttori di macchinari per la fabbricazione di altri prodotti } \\
\text { derivati dalla chimica }\end{array}$ & 3,96 & 3,43 & 3,55 & 4 & NON-G \\
\hline 7.2.3.1.0 & $\begin{array}{l}\text { Conduttori di macchinari per la confezione e vulcanizzazione dei } \\
\text { pneumatici }\end{array}$ & 4,48 & 3,75 & 3,94 & 4 & NON-G \\
\hline 7.2.3.2.0 & $\begin{array}{l}\text { Conduttori di macchinari per la fabbricazione di altri articoli in } \\
\text { gomma }\end{array}$ & 4 & 3,75 & 4,1 & 4 & NON-G \\
\hline 7.2.3.3.0 & $\begin{array}{l}\text { Conduttori di macchinari per la fabbricazione di articoli in } \\
\text { plastica e affini }\end{array}$ & 4,2 & 3,84 & 3,8 & 4 & NON-G \\
\hline 7.2.4.0.0 & $\begin{array}{l}\text { Addetti a macchinari per la produzione in serie di mobili e di } \\
\text { articoli in legno }\end{array}$ & 4,28 & 4,02 & 4,08 & 4 & NON-G \\
\hline 7.2.5.1.0 & $\begin{array}{l}\text { Conduttori di macchinari per tipografia e stampa su carta e } \\
\text { cartone }\end{array}$ & 4,67 & 4,28 & 4,24 & 4 & NON-G \\
\hline 7.2.5.2.0 & $\begin{array}{l}\text { Conduttori di macchinari per la fabbricazione di prodotti in carta } \\
\text { e cartone }\end{array}$ & 3,79 & 3,48 & 3,81 & 4 & NON-G \\
\hline 7.2.5.3.0 & Conduttori di macchinari per rilegatura di libri ed affini & 4,14 & 3,97 & 3,96 & 4 & NON-G \\
\hline 7.2.6.1.0 & Addetti a macchinari per la filatura e la bobinatura & 2,98 & 2,69 & 2,72 & 3 & NON-G \\
\hline
\end{tabular}




\begin{tabular}{|c|c|c|c|c|c|c|}
\hline 7.2.6.2.0 & $\begin{array}{l}\text { Addetti a telai meccanici e a macchinari per la tessitura e la } \\
\text { maglieria }\end{array}$ & 3,66 & 3,24 & 3,6 & 4 & NON-G \\
\hline 7.2.6.3.0 & $\begin{array}{l}\text { Operai addetti a macchinari industriali per confezioni di } \\
\text { abbigliamento in stoffa e affini }\end{array}$ & 3,6 & 3,37 & 3,42 & 4 & NON-G \\
\hline 7.2.6.4.0 & $\begin{array}{l}\text { Addetti a macchinari per il trattamento e la tintura di filati e } \\
\text { tessuti }\end{array}$ & 3,64 & 3,24 & 3,63 & 4 & NON-G \\
\hline 7.2.6.5.0 & Addetti a macchinari per la stampa dei tessuti & 3,96 & 3,7 & 3,52 & 4 & NON-G \\
\hline 7.2.6.9.1 & $\begin{array}{l}\text { Addetti a macchinari per la confezione in serie di passamanerie, } \\
\text { feltrerie e prodotti simili }\end{array}$ & 3,76 & 3,47 & 3,65 & 4 & NON-G \\
\hline 7.2.6.9.2 & $\begin{array}{l}\text { Addetti a macchinari industriali per la preparazione di pelli e } \\
\text { pellicce }\end{array}$ & 4,61 & 4,42 & 4,35 & 4 & NON-G \\
\hline 7.2 .6 .9 .3 & Addetti a macchinari per la produzione in serie di calzature & 4,42 & 4,3 & 4,06 & 4 & NON-G \\
\hline 7.2 .6 .9 .4 & Addetti a macchinari per la produzione in serie di articoli in pelle & 3,68 & 3,27 & 3,74 & 4 & NON-G \\
\hline 7.2.7.1.0 & Assemblatori in serie di parti di macchine & 3,5 & 3,2 & 3,21 & 3 & NON-G \\
\hline 7.2.7.2.0 & Assemblatori e cablatori di apparecchiature elettriche & 3,36 & 3,28 & 3,67 & 3 & NON-G \\
\hline 7.2.7.3.0 & $\begin{array}{l}\text { Assemblatori e cablatori di apparecchiature elettroniche e di } \\
\text { telecomunicazioni }\end{array}$ & 3,66 & 3,37 & 2,88 & 3 & NON-G \\
\hline 7.2.7.4.0 & $\begin{array}{l}\text { Assemblatori in serie di articoli in metallo, in gomma e in } \\
\text { materie plastiche }\end{array}$ & 3,38 & 3,73 & 3,49 & 4 & NON-G \\
\hline 7.2.7.5.0 & Assemblatori in serie di articoli in legno e in materiali affini & 4,08 & 3,29 & 3,57 & 4 & NON-G \\
\hline 7.2.7.6.0 & $\begin{array}{l}\text { Assemblatori in serie di articoli in cartone, in tessuto e materie } \\
\text { similari }\end{array}$ & 3,76 & 3,98 & 4,11 & 4 & NON-G \\
\hline 7.2.7.9.0 & Assemblatori in serie di articoli industriali compositi & 4,05 & 3,88 & 4,09 & 4 & NON-G \\
\hline 7.2.8.0.0 & $\begin{array}{l}\text { Addetti a macchine confezionatrici e al confezionamento di } \\
\text { prodotti industriali }\end{array}$ & 3,33 & 3,04 & 3,3 & 3 & NON-G \\
\hline 7.3 .1 .1 .1 & Addetti agli impianti fissi in agricoltura & 4,93 & 5,12 & 4,7 & 5 & NON-G \\
\hline 7.3.1.1.2 & Addetti agli impianti fissi nell'allevamento & 3,4 & 3,54 & 3,56 & 4 & NON-G \\
\hline 7.3 .1 .2 .0 & Addetti agli impianti per la trasformazione delle olive & 4,32 & 4,1 & 4,04 & 4 & NON-G \\
\hline 7.3.1.3.0 & $\begin{array}{l}\text { Addetti alla refrigerazione, trattamento igienico e prima } \\
\text { trasformazione del latte }\end{array}$ & 4,28 & 4,1 & 4,4 & 4 & NON-G \\
\hline 7.3.2.1.0 & $\begin{array}{l}\text { Conduttori di macchinari per la conservazione e la lavorazione } \\
\text { della carne e del pesce }\end{array}$ & 4,36 & 3,86 & 4,22 & 4 & NON-G \\
\hline 7.3.2.2.0 & $\begin{array}{l}\text { Conduttori di apparecchi per la lavorazione industriale di prodotti } \\
\text { lattiero-caseari }\end{array}$ & 3,6 & 3,31 & 3,7 & 4 & NON-G \\
\hline 7.3 .2 .3 .1 & Conduttori di macchinari industriali per la lavorazione dei cereali & 4,4 & 3,93 & 3,86 & 4 & NON-G \\
\hline 7.3.2.3.2 & $\begin{array}{l}\text { Conduttori di macchinari industriali per la lavorazione delle } \\
\text { spezie }\end{array}$ & 4,16 & 3,58 & 3,38 & 4 & NON-G \\
\hline 7.3.2.3.3 & $\begin{array}{l}\text { Conduttori di macchinari industriali per la lavorazione di prodotti } \\
\qquad \text { a base di cereali }\end{array}$ & 4,35 & 4,14 & 4,08 & 4 & NON-G \\
\hline 7.3.2.4.1 & $\begin{array}{l}\text { Conduttori di macchinari per cernita e la calibratura di prodotti } \\
\text { ortofrutticoli }\end{array}$ & 3,84 & 3,77 & 3,74 & 4 & NON-G \\
\hline 7.3.2.4.2 & Conduttori di macchinari per la conservazione di frutta e verdura & 3,6 & 3,59 & 3,58 & 4 & NON-G \\
\hline 7.3 .2 .4 .3 & Conduttori di macchinari per la conservazione di legumi e riso & 3,8 & 3,45 & 3,73 & 4 & NON-G \\
\hline 7.3 .2 .4 .4 & Conduttori di macchinari per la produzione di oli di semi & 4,24 & 4,18 & 4,32 & 4 & NON-G \\
\hline 7.3.2.5.0 & $\begin{array}{l}\text { Conduttori di macchinari per la produzione e la raffinazione dello } \\
\text { zucchero }\end{array}$ & 6,52 & 5,57 & 5,28 & 6 & NON-G \\
\hline
\end{tabular}




\begin{tabular}{|c|c|c|c|c|c|c|}
\hline 7.3.2.6.1 & $\begin{array}{l}\text { Conduttori di macchinari per la preparazione e la produzione del } \\
\text { the, del caffè e del cacao }\end{array}$ & 4,77 & 4,34 & 4,43 & 5 & NON-G \\
\hline 7.3.2.6.2 & $\begin{array}{l}\text { Conduttori di macchinari per la preparazione e la produzione } \\
\text { della cioccolata }\end{array}$ & 4,66 & 4,67 & 4,7 & 5 & NON-G \\
\hline 7.3.2.7.0 & $\begin{array}{l}\text { Conduttori di macchinari per la lavorazione dei prodotti del } \\
\text { tabacco }\end{array}$ & 4,38 & 4,39 & 4,29 & 4 & NON-G \\
\hline 7.3.2.8.1 & Addetti a macchinari industriali per la vinificazione & 4 & 4,04 & 3,98 & 4 & NON-G \\
\hline 7.3.2.8.2 & Addetti a macchinari industriali per la produzione di birra & 4,4 & 4,06 & 4,12 & 4 & NON-G \\
\hline 7.3.2.8.3 & $\begin{array}{l}\text { Addetti a macchinari industriali per la produzione di liquori, di } \\
\text { distillati e di bevande alcoliche }\end{array}$ & 3,95 & 4,08 & 4,02 & 4 & NON-G \\
\hline 7.3.2.8.4 & $\begin{array}{l}\text { Addetti a macchinari industriali per la produzione di bevande } \\
\text { analcoliche e gassate }\end{array}$ & 4,36 & 3,97 & 3,97 & 4 & NON-G \\
\hline 7.3.2.9.0 & $\begin{array}{l}\text { Conduttori di macchinari per la produzione di pasticceria e } \\
\text { prodotti da forno }\end{array}$ & 4,44 & 3,98 & 3,84 & 4 & NON-G \\
\hline 7.4.1.1.0 & Conduttori di locomotive & 4,64 & 4,02 & 3,97 & 4 & NON-G \\
\hline 7.4.1.2.0 & Frenatori, segnalatori ed agenti di manovra & 3,7 & 3,6 & 4,35 & 4 & NON-G \\
\hline 7.4.1.3.0 & Manovratori di impianti di funivia & 4,02 & 4,17 & 4,33 & 4 & NON-G \\
\hline 7.4.2.2.0 & Autisti di taxi, conduttori di automobili e di furgoni & 3,56 & 3,56 & 3,89 & 4 & NON-G \\
\hline 7.4.2.3.0 & Conduttori di autobus, di tram e di filobus & 3,72 & 3,4 & 3,74 & 4 & NON-G \\
\hline 7.4.2.4.0 & Conduttori di mezzi pesanti e camion & 3,47 & 3,2 & 3,32 & 3 & NON-G \\
\hline 7.4.2.5.0 & Conduttori di veicoli a trazione animale & 3,36 & 3,59 & 4,02 & 4 & NON-G \\
\hline 7.4.3.1.0 & Conduttori di trattori agricoli & 4,37 & 3,69 & 3,92 & 4 & NON-G \\
\hline 7.4.3.2.0 & $\begin{array}{l}\text { Conduttori di macchine raccoglitrici, trinciatrici e pressatrici } \\
\text { agricole }\end{array}$ & 4,48 & 4,15 & 4,06 & 4 & NON-G \\
\hline 7.4.3.3.0 & Conduttori di mietitrebbiatrici & 4,8 & 3,93 & 3,84 & 5 & NON-G \\
\hline 7.4.3.4.0 & $\begin{array}{l}\text { Conduttori di macchine per la raccolta di prodotti agricoli } \\
\text { (barbabietole, patate, frutta, uva e ortive) }\end{array}$ & 4,26 & 4,2 & 4,13 & 4 & NON-G \\
\hline 7.4.3.5.0 & Conduttori di macchine forestali & 3,63 & 3,52 & 3,68 & 4 & NON-G \\
\hline 7.4.4.1.0 & Conduttori di macchinari per il movimento terra & 4,08 & 4,04 & 4,13 & 4 & NON-G \\
\hline 7.4.4.2.0 & Conduttori di macchinari mobili per la perforazione in edilizia & 3,92 & 3,8 & 3,86 & 4 & NON-G \\
\hline 7.4.4.3.0 & Conduttori di gru e di apparecchi di sollevamento & 2,69 & 2,96 & 3,04 & 3 & NON-G \\
\hline 7.4.4.4.0 & Conduttori di carrelli elevatori & 3,44 & 3,14 & 3,69 & 3 & NON-G \\
\hline 7.4.5.1.0 & Marinai di coperta & 4,03 & 4,05 & 3,97 & 4 & NON-G \\
\hline 7.4.5.2.0 & Conduttori di caldaie ed altre attrezzature navali & 4,65 & 4,56 & 4,56 & 5 & NON-G \\
\hline 7.4.5.3.0 & Conduttori di barche e battelli & 4,52 & 4,03 & 4,02 & 4 & NON-G \\
\hline 8.1 .1 .1 .0 & Uscieri, commessi ed assimilati & 2,88 & 2,92 & 3,32 & 3 & NON-G \\
\hline 8.1 .1 .2 .0 & Lettori di contatori, collettori di monete ed assimilati & 4,14 & 4,34 & 5 & 4 & NON-G \\
\hline 8.1.2.1.0 & Facchini, addetti allo spostamento merci ed assimilati & 2,92 & 3,01 & 3,17 & 3 & NON-G \\
\hline 8.1.2.2.0 & $\begin{array}{l}\text { Personale ausiliario addetto all'imballaggio, al magazzino ed alla } \\
\text { consegna merci }\end{array}$ & 2,88 & 3,04 & 3,21 & 3 & NON-G \\
\hline $8.1 \cdot 2.3 .0$ & Portalettere e fattorini postali & 3,32 & 3,93 & 3,6 & 4 & NON-G \\
\hline 8.2 .1 .1 .0 & Venditori ambulanti di ortofrutticoli & 3,32 & 3,29 & 3,79 & 3 & NON-G \\
\hline 8.2 .1 .2 .0 & Venditori ambulanti di prodotti alimentari non ortofrutticoli & 3,8 & 4,21 & 4,51 & 4 & NON-G \\
\hline $8.2 \cdot 1 \cdot 3.0$ & Venditori ambulanti di manufatti o di servizi & 3,6 & 3,99 & 4,13 & 4 & NON-G \\
\hline
\end{tabular}




\begin{tabular}{|c|c|c|c|c|c|c|}
\hline 8.2.2.1.0 & $\begin{array}{c}\text { Personale addetto alla pulizia in esercizi alberghieri, } \\
\text { extralberghieri e sulle navi }\end{array}$ & 2,88 & 3,16 & 3,2 & 3 & NON-G \\
\hline 8.2 .2 .2 .0 & Personale non qualificato addetto alla ristorazione & 2,36 & 2,32 & 2,76 & 2 & NON-G \\
\hline 8.3 .1 .0 .0 & Bidelli ed assimilati & 3,16 & 3,49 & 3,8 & 3 & NON-G \\
\hline 8.3.2.0.0 & Portantini ed assimilati & 3,76 & 4,08 & 4,17 & 4 & NON-G \\
\hline 8.4 .1 .0 .0 & Personale non qualificato nei servizi ricreativi e culturali & - & 4,59 & 4,62 & 5 & NON-G \\
\hline 8.4.2.1.0 & Collaboratori domestici ed assimilati & 2,96 & 2,63 & 2,47 & 3 & NON-G \\
\hline 8.4.2.2.0 & $\begin{array}{l}\text { Addetti non qualificati a servizi di pulizia in imprese ed enti } \\
\text { pubblici ed assimilati }\end{array}$ & 2,64 & 2,84 & 3,16 & 3 & NON-G \\
\hline 8.4 .2 .3 .0 & Spazzini e altri raccoglitori di rifiuti ed assimilati & 2,96 & 2,52 & 2,64 & 3 & NON-G \\
\hline 8.4.3.1.0 & Garzoni di barbiere, di parrucchiere, manicure ed assimilati & 3,68 & 3,76 & 3,93 & 4 & NON-G \\
\hline 8.4 .3 .2 .0 & Lustrascarpe ed altri mestieri di strada & - & 3,51 & 3,81 & 4 & NON-G \\
\hline 8.4.4.0.0 & $\begin{array}{l}\text { Personale non qualificato addetto alla custodia di edifici, di } \\
\text { impianti e di attrezzature }\end{array}$ & 3,12 & 3,48 & 3,03 & 3 & NON-G \\
\hline 8.5 .1 .0 .0 & Braccianti agricoli & 4,8 & 2,66 & 3,15 & 5 & NON-G \\
\hline 8.5 .2 .1 .0 & Personale forestale non qualificato & 2,72 & 2,67 & 2,82 & 3 & NON-G \\
\hline 8.5.2.2.0 & Personale non qualificato addetto alla cura degli animali & 2,96 & 3,35 & 2,86 & 3 & NON-G \\
\hline 8.5 .2 .3 .0 & Personale non qualificato addetto alla pesca ed alla caccia & 3,36 & 3,03 & 3,14 & 3 & NON-G \\
\hline 8.6.1.0.0 & $\begin{array}{l}\text { Manovali ed altro personale non qualificato delle miniere e delle } \\
\text { cave }\end{array}$ & 3,76 & 3,7 & 3,56 & 4 & NON-G \\
\hline 8.6.2.1.0 & $\begin{array}{l}\text { Manovali e personale non qualificato dell'edilizia civile ed } \\
\text { assimilati }\end{array}$ & 3,6 & 3,15 & 3,57 & 3 & NON-G \\
\hline 8.6.2.2.0 & $\begin{array}{l}\text { Manovali e personale non qualificato della costruzione e } \\
\text { manutenzione di strade, dighe e altre opere pubbliche }\end{array}$ & 3,07 & 2,67 & 3,16 & 3 & NON-G \\
\hline 8.6 .3 .0 .0 & Personale non qualificato delle attività industriali ed assimilati & 2,66 & 2,59 & 3 & 3 & NON-G \\
\hline
\end{tabular}




\section{APPENDIX 4}

Estimates shown in subparagraph $\$ 2.3$ are obtained as OLS estimates of the linear regression model specificated as follows:

$$
\ln W_{i}=\delta E \quad S O C_{-} E X P_{i}+\delta_{S} S O C_{-} S T R_{i}+\delta_{C} S O C_{-} C O M_{i}+\delta_{D} C_{N O N T R O L S}+\varepsilon_{i}
$$

Where $\operatorname{CONTROLS}_{\boldsymbol{i}}$ is a vector of controls, all of which are described in Table A.4

Table A.4 Variables description

\begin{tabular}{|c|c|}
\hline Variable name & Description \\
\hline $\ln \mathrm{W}$ & Natural logarithm of gross monthly earnings (Dependent Variable) \\
\hline SOC_EXP & $\begin{array}{l}\text { Dummy variable for being employed in Experts occupational group; } D=1 \text { if } \\
\text { employed, } D=0 \text { otherwise }\end{array}$ \\
\hline SOC_ORC & $\begin{array}{l}\text { Dummy variable for being employed in Orchestrators occupational group; } D=1 \\
\text { if employed, } D=0 \text { otherwise }\end{array}$ \\
\hline SOC_COM & $\begin{array}{l}\text { Dummy variable for being employed in Communicators occupational group; } \\
D=1 \text { if employed, } D=0 \text { otherwise }\end{array}$ \\
\hline AGE & Age at the time of the interview \\
\hline TENURE & Job tenure defined as time spent in the current job, measured in years \\
\hline PART_TIME & $\begin{array}{l}\text { Dummy variable for being part-time workersg: } D=1 \text { if employed in part-time } \\
\text { jobs, } D=0 \text { otherwise }\end{array}$ \\
\hline GENDER & Dummy variable for gender: $\mathrm{D}=1$ if male, $\mathrm{D}=0$ otherwise \\
\hline DISTRETTO_NW & Working area: $\mathrm{D}=1$ if North-West district, $\mathrm{D}=0$ otherwise \\
\hline DISTRETTO_NE & Working area: $\mathrm{D}=1$ if North-East district, $\mathrm{D}=0$ otherwise \\
\hline DISTRETTO_C & Working area: $\mathrm{D}=1$ if Central district, $\mathrm{D}=0$ otherwise \\
\hline DISTRETTO_S & Working area: $\mathrm{D}=1$ if South district, $\mathrm{D}=0$ otherwise \\
\hline
\end{tabular}

DISTRETTO_S Working area: $\mathrm{D}=1$ if South district, $\mathrm{D}=0$ otherwise 


\begin{tabular}{|c|c|}
\hline DISTRETTO_I & Working area: $\mathrm{D}=1$ if Isles district, $\mathrm{D}=0$ otherwise \\
\hline AGRICOLTURA & Industry: $\mathrm{D}=1$ if Agriculture, $\mathrm{D}=0$ otherwise \\
\hline ENERGIA & Industry: $\mathrm{D}=1$ if Energy and Mining, $\mathrm{D}=0$ otherwise \\
\hline MANIFATTURA & Industry: $\mathrm{D}=1$ if Manufacturing, $\mathrm{D}=0$ otherwise \\
\hline COSTRUZIONI & Industry: $\mathrm{D}=1$ if Construction, $\mathrm{D}=0$ otherwise \\
\hline COMMERCIO & Industry: $\mathrm{D}=1$ if Retail and Wholesale, $\mathrm{D}=0$ otherwise \\
\hline TURISMO & Industry: $\mathrm{D}=1$ if Tourism, $\mathrm{D}=0$ otherwise \\
\hline TRASPORTI & Industry: $\mathrm{D}=1$ if Transports, Warehousing and Logistics, $\mathrm{D}=0$ otherwise \\
\hline FINANZA & Industry: $\mathrm{D}=1$ if Finance and Insurance Services, $\mathrm{D}=0$ otherwise \\
\hline SERVIZI & Industry: $\mathrm{D}=1$ if Other Firms and Business Services, $\mathrm{D}=0$ otherwise \\
\hline PUBBLICO & Industry: $\mathrm{D}=1$ if Public Administration, $\mathrm{D}=0$ otherwise \\
\hline WELFARE & Industry: $\mathrm{D}=1$ if Public Health and Care, $\mathrm{D}=0$ otherwise \\
\hline
\end{tabular}


Table A.5 Linear regression model with OLS estimates of the impacts on earnings of SOC(HE)-Italy groups

\begin{tabular}{|c|c|c|c|}
\hline & $\begin{array}{c}(1) \\
\ln W\end{array}$ & $\begin{array}{c}(2) \\
\ln W\end{array}$ & $\begin{array}{c}(3) \\
\ln W\end{array}$ \\
\hline SOC_EXP & $\begin{array}{c}0.2884 * * * \\
(0.0052)\end{array}$ & $\begin{array}{c}0.2082 * * * \\
(0.0043)\end{array}$ & $\begin{array}{c}0.1756 * * * \\
(0.0043)\end{array}$ \\
\hline SOC_ORC & $\begin{array}{c}0.3475 * * * \\
(0.0241)\end{array}$ & $\begin{array}{c}0.2858 * * * \\
(0.0202)\end{array}$ & $\begin{array}{c}0.2590 * * * \\
(0.0201)\end{array}$ \\
\hline SOC_COM & $\begin{array}{c}0.4010 * * * \\
(0.0069)\end{array}$ & $\begin{array}{c}0.2535 * * * \\
(0.0061)\end{array}$ & $\begin{array}{c}0.1699 * * * \\
(0.0066)\end{array}$ \\
\hline AGE & & $\begin{array}{c}0.0032 * * * \\
(0.0002)\end{array}$ & $\begin{array}{c}0.0032 * * * \\
(0.0002)\end{array}$ \\
\hline TENURE & & $\begin{array}{c}0.0065 * * * \\
(0.0002)\end{array}$ & $\begin{array}{c}0.0073 * * * \\
(0.0002)\end{array}$ \\
\hline PART_TIME & & $\begin{array}{c}-0.4949 * * * \\
(0.0056)\end{array}$ & $\begin{array}{c}-0.4870 * * * \\
(0.0055)\end{array}$ \\
\hline GENDER & & $\begin{array}{c}0.1446 * * * \\
(0.0037)\end{array}$ & $\begin{array}{c}0.1462 * * * \\
(0.0036)\end{array}$ \\
\hline DISTRETTO_NW & & $\begin{array}{c}0.0509 * * * \\
(0.0048)\end{array}$ & $\begin{array}{c}0.0569 * * * \\
(0.0047)\end{array}$ \\
\hline DISTRETTO_NE & & $\begin{array}{c}0.0648 * * * \\
(0.0050)\end{array}$ & $\begin{array}{c}0.0707 * * * \\
(0.0050)\end{array}$ \\
\hline DISTRETTO_S & & $\begin{array}{c}-0.0705 * * * \\
(0.0053)\end{array}$ & $\begin{array}{c}-0.0675 * * * \\
(0.0052)\end{array}$ \\
\hline DISTRETTO_I & & $\begin{array}{c}-0.0784 * * * \\
(0.0068)\end{array}$ & $\begin{array}{c}-0.0740 * * * \\
(0.0067)\end{array}$ \\
\hline AGRICOLTURA & & $\begin{array}{c}-0.0789 * * * \\
(0.0131)\end{array}$ & $\begin{array}{c}-0.0704 * * * \\
(0.0130)\end{array}$ \\
\hline ENERGIA & & $\begin{array}{c}0.2688 * * * \\
(0.0154)\end{array}$ & $\begin{array}{c}0.2690 * * * \\
(0.0152)\end{array}$ \\
\hline MANIFATTURA & & $\begin{array}{c}0.1579 * * * \\
(0.0078)\end{array}$ & $\begin{array}{c}0.1648 * * * \\
(0.0078)\end{array}$ \\
\hline COSTRUZIONI & & $\begin{array}{c}0.1319 * * * \\
(0.0092)\end{array}$ & $\begin{array}{c}0.1434 * * * \\
(0.0092)\end{array}$ \\
\hline COMMERCIO & & $\begin{array}{c}0.1554 * * * \\
(0.0083)\end{array}$ & $\begin{array}{c}0.1624 * * * \\
(0.0083)\end{array}$ \\
\hline
\end{tabular}




\begin{tabular}{|c|c|c|c|}
\hline TURISMO & & $\begin{array}{c}0.0779 * * * \\
(0.0108)\end{array}$ & $\begin{array}{c}0.0856^{* * * *} \\
(0.0108)\end{array}$ \\
\hline TRASPORTI & & $\begin{array}{c}0.2281 * * * \\
(0.0095)\end{array}$ & $\begin{array}{c}0.2311^{* * * *} \\
(0.0095)\end{array}$ \\
\hline FINANZA & & $\begin{array}{c}0.3520^{* * *} \\
(0.0116)\end{array}$ & $\begin{array}{c}0.3458^{* * * *} \\
(0.0115)\end{array}$ \\
\hline SERVIZI & & $\begin{array}{c}0.1258^{* * *} * \\
(0.0094)\end{array}$ & $\begin{array}{c}0.1175^{* * * *} \\
(0.0093)\end{array}$ \\
\hline PUBBLICO & & $\begin{array}{c}0.2616^{* * * *} \\
(0.0087)\end{array}$ & $\begin{array}{c}0.2473^{* * * *} \\
(0.0087)\end{array}$ \\
\hline WELFARE & & $\begin{array}{c}0.2442 * * * \\
(0.0081)\end{array}$ & $\begin{array}{c}0.2130 * * * * \\
(0.0080)\end{array}$ \\
\hline GRADUATE & & & $\begin{array}{c}0.1835^{* * * *} \\
(0.0055)\end{array}$ \\
\hline _cons & $\begin{array}{c}6.9510^{* * * *} \\
(0.0025)\end{array}$ & $\begin{array}{c}6.5876^{* * * *} \\
(0.0108)\end{array}$ & $\begin{array}{c}6.5622 * * * * \\
(0.0107) \\
\end{array}$ \\
\hline$N$ & 42720 & 42720 & 42720 \\
\hline$R^{2}$ & 0.108 & 0.479 & 0.495 \\
\hline adj. $R^{2}$ & 0.1082 & 0.4786 & 0.4943 \\
\hline
\end{tabular}




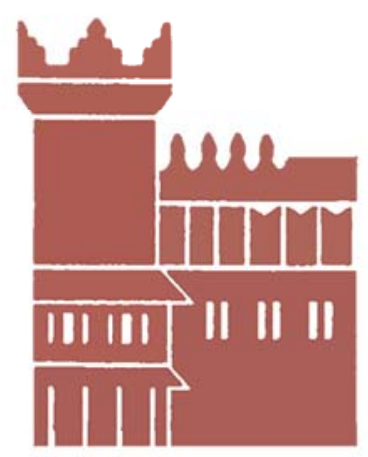

Alma Mater Studiorum - Università di Bologna DEPARTMENT OF ECONOMICS

Strada Maggiore 45

40125 Bologna - Italy

Tel. +39051 2092604

Fax +390512092664

http://www.dse.unibo.it 